Geologic Cross Section I-I' Through the Appalachian Basin from the Eastern Margin of the Illinois Basin, Jefferson County, Kentucky, to the Valley and Ridge Province, Scott County, Virginia

By Robert T. Ryder, Michael H. Trippi, and Christopher S. Swezey

Pamphlet $A$ to accompany

Scientific Investigations Map 3343 


\section{U.S. Department of the Interior SALLY JEWELL, Secretary}

\section{U.S. Geological Survey}

Suzette M. Kimball, Acting Director

U.S. Geological Survey, Reston, Virginia: 2015

For more information on the USGS —-the Federal source for science about the Earth, its natural and living resources, natural hazards, and the environment-visit http://www.usgs.gov or call 1-888-ASK-USGS.

For an overview of USGS information products, including maps, imagery, and publications, visit http://www.usgs.gov/pubprod/.

Any use of trade, firm, or product names is for descriptive purposes only and does not imply endorsement by the U.S. Government.

Although this information product, for the most part, is in the public domain, it also may contain copyrighted materials as noted in the text. Permission to reproduce copyrighted items must be secured from the copyright owner.

Suggested citation:

Ryder, R.T., Trippi, M.H., and Swezey, C.S., 2015, Geologic cross section I-I'through the Appalachian basin from the eastern margin of the Illinois basin, Jefferson County, Kentucky, to the Valley and Ridge province, Scott County, Virginia: U.S. Geological Survey Scientific Investigations Map 3343, 2 sheets and pamphlet A, 41 p.; pamphlet B, 102 p., http://dx.doi.org/10.3133/sim3343.

ISSN 2329-1311 (print)

ISSN 2329-132X (online)

ISBN 978-1-4113-3973-6 


\section{Contents}

\section{Pamphlet A}

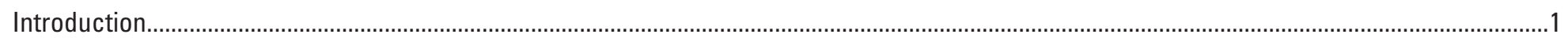

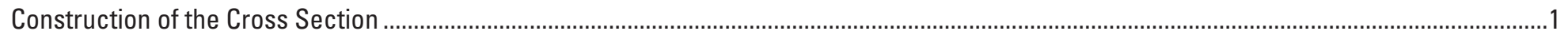

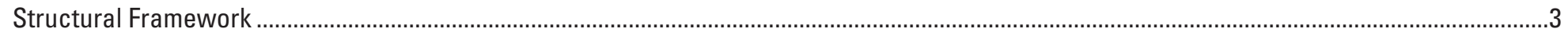

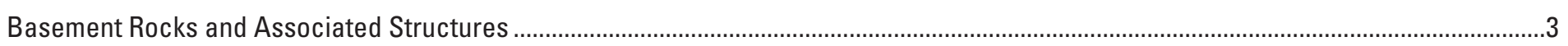

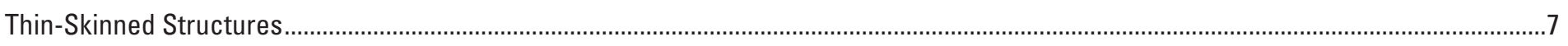

Stratigraphic Framework

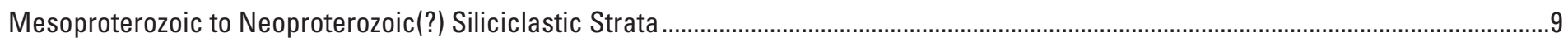

Lower Cambrian to Upper Ordovician Siliciclastic and Carbonate Strata...........................................................................................10

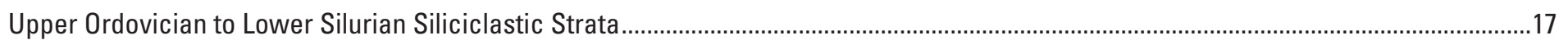

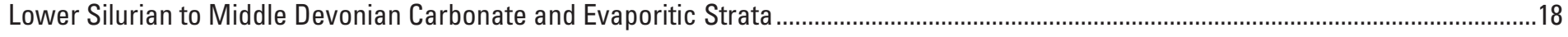

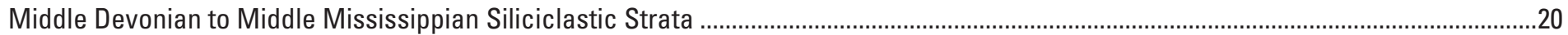

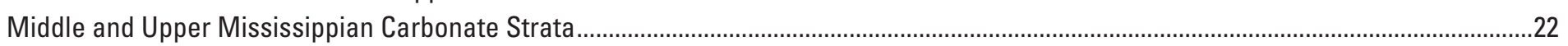

Upper Mississippian and Pennsylvanian Siliciclastic Strata ...............................................................................................................2

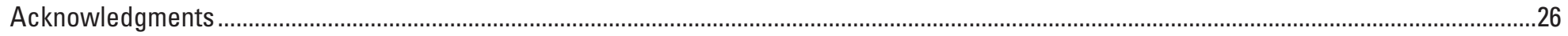

References Cited

\section{Pamphlet B}

Appendix 1. Table Summarizing Stratigraphic Units and Depths of Stratigraphic Units for Drill Holes 1-10 in Cross Section I-I'.....................1

Appendix 2. Table Summarizing Stratigraphic Units and Depths of Stratigraphic Units for Drill Holes 11-19 in Cross Section I-I'..................49

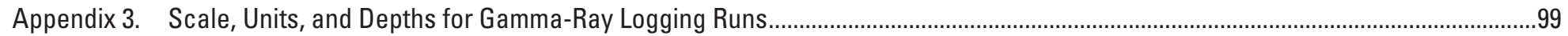




\section{Figures}

[On map sheets]

1. Map of Kentucky, Virginia, and adjoining States showing location of cross section $I-I$ ' and selected tectonic features.

2. Correlation chart of Paleozoic rocks along cross section $I-l$ ' in Kentucky and Virginia.

3. Diagram showing major footwall ramps (thrust faults) and zones of bedding-plane detachment in the eastern part of cross section $I-l$ '.

\section{Table}

[In pamphlet A]

1. Drill holes used in cross section $I-I^{\prime}$

\section{Conversion Factors}

\begin{tabular}{|c|c|c|}
\hline Multiply & By & To obtain \\
\hline \multicolumn{3}{|c|}{ Length } \\
\hline foot $(\mathrm{ft})$ & 0.3048 & meter $(\mathrm{m})$ \\
\hline meter $(\mathrm{m})$ & 3.281 & foot $(\mathrm{ft})$ \\
\hline mile (mi) & 1.609 & kilometer $(\mathrm{km})$ \\
\hline kilometer $(\mathrm{km})$ & 0.6214 & mile (mi) \\
\hline
\end{tabular}




\title{
Geologic Cross Section I-I'Through the Appalachian Basin from the Eastern Margin of the Illinois Basin, Jefferson County, Kentucky, to the Valley and Ridge Province, Scott County, Virginia
}

\author{
By Robert T. Ryder, Michael H. Trippi, and Christopher S. Swezey
}

\section{Introduction}

Geologic cross section $I-I^{\prime}$ is the fourth in a series of cross sections constructed by the U.S. Geological Survey (USGS) to document and improve understanding of the geologic framework and petroleum systems of the Appalachian basin. Cross section $I-I^{\prime}$ (fig. 1) provides a regional view of the structural and stratigraphic framework of the Appalachian basin from the eastern margin of the Illinois basin in central Kentucky, across the Cincinnati arch (Lexington dome), to the Valley and Ridge province in southwestern Virginia, a distance of approximately 280 miles (mi). This cross section is a companion to cross sections $E-E^{\prime}, D-D^{\prime}$, and $C-C^{\prime}$ (Ryder, Swezey, and others, 2008; Ryder and others, 2009; Ryder and others, 2012) that are located approximately 200 to $300 \mathrm{mi}$ to the northeast (fig. 1).

Cross section $I-I^{\prime}$ either updates or complements earlier geologic cross sections through the central Kentucky and southwestern Virginia part of the Appalachian basin by Renfro and Feray (1970), Black (1989), Rankin and others (1991), and Hickman (2004), and restored stratigraphic cross sections by Colton (1970) and Harris and Milici (1977). Although other published cross sections through parts of the basin show more structural detail (for example, Black, 1968; Alvord and Miller, 1972;
Evans and Troensegaard, 1991) and stratigraphic detail (for example, Read, 1980; Mitchell, 1982; Englund and Thomas, 1990; Pope and Read, 1997; Harris and Sparks, 2000; Hickman, 2004; Riley and others, 2006; Ryder, Crangle, and others, 2008), these other cross sections are of more limited extent geographically and (or) stratigraphically.

Cross section $I-I^{\prime}$ contains much information that is useful for evaluating energy resources in the Appalachian basin. Although the Appalachian basin petroleum systems identified by Swezey (2002) and Milici and others (2003) are not shown on the cross section, many of their key elements (such as source rocks, reservoir rocks, seals, and traps) can be inferred from lithologic units, unconformities, and geologic structures shown on the cross section. Other aspects of petroleum systems (such as the timing of petroleum generation and petroleum migration pathways) may be evaluated by burial history, thermal history, and fluid flow models on the basis of what is shown on the cross section. Cross section $I-I^{\prime}$ also provides a stratigraphic and structural framework for the Pennsylvanian coal-bearing section, although the cross section lacks the detail to illustrate key elements of coal systems such as coal quality (composition) and coal rank. In addition, cross section $I-I^{\prime}$ may be used as a reconnaissance tool to identify plausible geologic structures and strata for the subsurface storage of liquid waste (for example, Colton, 1961; Lloyd and Reid, 1990; Clark and others, 2005) or for the sequestration of carbon dioxide (for example, Smith and others, 2002; Lucier and others, 2006; Greb and others, 2012)

\section{Construction of the Cross Section}

Cross section $I-I^{\prime}$ is oriented northwest-southeast, approximately normal to the structural grain of the region. Several abrupt bends in the section, however, are required to accommodate key drill holes that penetrate the entire section of Paleozoic sedimentary rocks.

Cross section $I-I^{\prime}$ is based on geological and geophysical data from 19 deep drill holes, 10 of which penetrate the Paleozoic sedimentary rocks of the basin and bottom in Mesoproterozoic crystalline basement rocks of the Grenville province or eastern granite-rhyolite province. The locations of the tops of each stratigraphic unit penetrated in the 19 deep drill holes were converted from depth in feet (ft) below the kelly bushing (KB) to depth below ground level (GL), and then were plotted on the cross section with respect to mean sea 
level (MSL). Detailed depth information for the tops of the stratigraphic units in each well is reported in appendixes 1 and 2 .

The correlation of stratigraphic intervals between drill holes was based on a variety of geophysical (wireline) and lithologic logs. The most commonly used geophysical logs were the gamma ray-neutron and gamma ray-density log suites, whereas the most commonly used lithologic logs were those produced by the Geological Sample Log Company (table 1). Gamma-ray logs used for correlations were digitized as Log ASCII files (LAS), converted to graphic images, and then plotted next to their respective drill holes. The lithology assigned to each stratigraphic interval was simplified to just a few rock types and lithologic modifiers.

The data from drill holes were supplemented by data on topography and bedrock geology. For example, the topographic profile for the cross section was created from a Shuttle Radar Topography Mission (SRTM) 90-m-grid digital elevation model (DEM) for parts of Kentucky and Virginia. This topographic profile is approximate and should not be used to determine accurate surface elevations. The original website accessed in 2009 for DEM data is no longer accessible, but equivalent DEM data can be found at http:// srtm.csi.cgiar.org/. Some details of the Pennsylvanian stratigraphy in eastern Kentucky were obtained from bedrock geologic maps such as those by Donnell and Johnston (1963), Jenkins (1967), Outerbridge (1968), Weir and Richards (1974), Hinrichs and Ping (1978), and Sable (1978). The nomenclature for Pennsylvanian strata follows Greb and others $(2004,2009)$. Similar details of the Pennsylvanian stratigraphy in southwestern Virginia were obtained from bedrock geologic maps by Meissner (1978) and Mitchell and others (1984). Also, pre-Pennsylvanian stratigraphic units in the cross section were tied to the outcrop using geologic maps of Kentucky (Cressman, 1964, 1975a,b; MacQuown, 1968; and McDowell, 1978) and of Virginia (Evans and Troensegaard, 1991; Bartlett and Webb, 1971; Virginia Division of Mineral Resources, 1993).
Although some correlations shown on cross section $I-I^{\prime}$ are based on the authors' interpretations, many correlations are adopted or modified from previous publications, and stratigraphic nomenclature follows existing terminology wherever possible. Useful references for stratigraphic correlations and (or) nomenclature include the following: Colton (1970), Harris and Milici (1977), Le Van and Rader (1983), Patchen and others (1985), Milici and de Witt (1988), Swezey (2002), and Noger and Drahozal (2005) for the entire Paleozoic section; Read (1980), Webb (1980), Cressman (1973), Weir and others (1984), Riley and others (1993, 2006), Ryder, Crangle, and others (2008), and Harris and others (2004) for Cambrian and Ordovician rocks; Wilson and others (1981a,b), McDowell (1983), Currie and MacQuown (1984), Brett and others (1990), Dorsch and others (1994), and Meglen and Noger (1996) for Silurian rocks; Wilson and others (1981a,b), de Witt and others (1993), and Filer (2002, 2003) for Devonian rocks; Averitt (1941), Englund (1979), Englund and Thomas (1990), Sable and Dever (1990), Chesnut (1992), Harris and Sparks (2000), Greb and others (2004, 2009), and Stamm (2004) for Mississippian and Pennsylvanian rocks. A correlation chart for all the stratigraphic units identified along cross section $I-I^{\prime}$ is shown in figure 2.

Only selected unconformities are shown on cross section $I-I^{\prime}$. Regional unconformities shown on section $I-I^{\prime}$ and in figure 2 include (1) the basal Cambrian unconformity (see Read, 1989a; Harris and Baranoski, 1996 for the stratigraphic location), (2) the Middle Ordovician (Knox) unconformity (Harris and Repetski, 1982; Mussman and others, 1988), (3) the Upper Ordovician to lower Silurian Cherokee unconformity (Dennison and Head, 1975; Brett and others, 1990), (4) the Lower to Middle Devonian Wallbridge unconformity (Dennison and Head, 1975), (5) the Middle to Upper Devonian unconformity (de Witt and others, 1993), and (6) the Lower Pennsylvanian unconformity (Rice and Schwietering, 1988; Ettensohn, 1992a). The correlation of these unconformities with North American sequences of Sloss $(1963,1988)$ and Wheeler $(1963)$ is shown on figure 2 and by Ettensohn (1994) and Swezey (2002, 2009).

Basement-involved structures along cross section $I-I^{\prime}$ are modified from (1) structure-contour maps by Shumaker (1996), Drahovzal and Noger (1995), and Hickman and others (2006); (2) from seismic-based interpretations by Black (1989) and Hickman and others (2006); and (3) from an unpublished single-fold seismic profile (GTS31-1a) provided by John Hickman of the Kentucky Geological Survey in 2009. Thinskinned structures such as the Pine Mountain, St. Paul (Hunter Valley), Dumps, Honaker, and Copper Creek thrust faults and a complex, unnamed ramp anticline penetrated by well 18 are displayed on cross section $I-I^{\prime}$ mainly on the basis of interpretations by Woodward (1985) and Evans and Troensegaard (1991) and from lithologic descriptions by L.D. Harris (unpub. data, 1979). Another thin-skinned structure, the Russell Fork fault (fig. 1), is recognized as a transverse fault and lateral ramp (Harris and Milici, 1977; Meissner, 1978).

As defined by Rodgers (1970), the Allegheny structural front in southwestern Virginia and adjoining Tennessee separates low-dipping strata of the Cumberland Plateau (of the Appalachian Plateau province) on the northwest from steeper dipping and thrust-faulted strata of the Valley and Ridge province on the southeast (fig. 1). The Allegheny structural front is located in southwestern Virginia at the eastern end of the St. Paul (Hunter Valley) thrust fault near its junction with the Dumps thrust fault (Rodgers, 1970; Evans and Troensegaard, 1991). About 5 to 10 mi southwest of cross section $I-I^{\prime}$, the Allegheny structural front shifts slightly to the north to wrap around the northern flank of the Powell Valley anticline (Rodgers, 1970).

The location of the Cincinnati arch (Lexington dome) on cross section $I-I^{\prime}$ is based on the geologic map of Kentucky (McDowell and others, 1981). In addition, the eastward homoclinal regional dip of middle and upper Paleozoic strata on the eastern side of the arch, as shown on cross section $I-I^{\prime}$, is based 
on a structure-contour map on the base of the Devonian Ohio Shale (Dillman and Ettensohn, 1980). The westward dip of strata from the arch toward the Illinois basin, as shown on cross section $I-I^{\prime}$, is based on structure-contour maps on the top of the Cambrian and Ordovician Knox Group (McGuire and Howell, 1963), on the top of the Ordovician Tyrone Limestone (Black, 1989), and on the base of the Devonian New Albany Shale (Schwalb and Norris, 1980).

\section{Structural Framework}

The St. Paul (Hunter Valley) thrust fault and an underlying unnamed ramp anticline drilled by well 18 mark the western margin of the Valley and Ridge province (fig. 1), where a thick panel of Cambrian to Ordovician carbonate rocks was decoupled from underlying strata and was thrust about 4 to $5 \mathrm{mi}$ west up a major tectonic ramp (footwall ramp, using terminology of McClay, 1992) of the Pine Mountain thrust fault system. This footwall ramp connects a basal zone of detachment (footwall flat; McClay, 1992) in the Cambrian Shady Dolomite with an upper zone of detachment (hangingwall flat; McClay, 1992) in the Devonian Marcellus Shale and (or) Rhinestreet Shale (fig. 3). The upper detachment zone of the Pine Mountain thrust fault system extends west from beneath the unnamed anticline for about $32 \mathrm{mi}$ along the Marcellus Shale and (or) Rhinestreet Shale before the zone breaks upsection along a secondary tectonic ramp (secondary footwall ramp) through rocks as young as Pennsylvanian (fig. 3). The net shortening in the unnamed ramp anticline is about 6 to $7 \mathrm{mi}$ when accounting for folding and secondary thrust faults in the core of the structure. The duplication of the Cambrian Shady Dolomite and Cambrian Rome Formation in the unnamed ramp anticline has created a net structural relief of approximately $1.7 \mathrm{mi}(9,000 \mathrm{ft})$

On cross section $I-I^{\prime}$, the location of the basal detachment zone in the Shady Dolomite is based solely on the presence of stacked thrust sheets composed of Shady Dolomite in the unnamed ramp anticline penetrated by drill hole 18 (L.D. Harris, written communication to J.A. Cramer, Jr., Exxon Company, July 9,1979 ) and on the presence of anhydrite beds in the Shady Dolomite in drill hole 18 (both in the parautochthonous section near the bottom of the drill hole and the allochthonous horse blocks in the Pine Mountain thrust sheet, discussed later in the text). This placement contradicts previous work by Harris and Milici (1977) and Kulander and Dean (1986), who placed the basal detachment zone in the Cambrian Rome Formation.

The upper detachment zone of the Pine Mountain thrust fault continues west for an additional 35 to 40 mi beyond the secondary footwall ramp, as a secondary bedding plane fault in the Devonian Rhinestreet Shale (Shumaker, 1978). Another bedding plane fault located within the lower part of the Devonian Huron Shale extends even farther west beyond the secondary tectonic ramp of the Pine Mountain thrust fault (Shumaker, 1978). These secondary bedding plane faul zones described by Shumaker (1978) occur in Devonian organic-rich shale beds and are characterized in core samples by horizontal and inclined fractures with slickensides.

Typical Appalachian basement-involved structures are predominantly extensional faults, several of which may have resulted from Neoproterozoic to earliest Cambrian rifting of the eastern continental margin of North America (Rankin and others, 1989; Thomas, 1991). This rifting event was followed by the opening of the Iapetus Ocean and the construction of a passive margin along the eastern margin of North America (Rankin and others, 1989; Thomas, 1991). A Middle Cambrian rifting event, which was more moderate in scale than the Neoproterozoic-earliest Cambrian rifting event, formed the Rome trough about $200 \mathrm{mi}$ inland from the evolving passive margin (Beardsley and Cable, 1983; Read, 1989a,b; Shumaker, 1996). A major basement fault near the crest of the Cincinnati arch, between wells 4 and 5, shows normal (extensional) offset. This fault, however, was originally a west-verging thrust fault that placed Proterozoic Grenville-age crystalline basement rocks against crystalline basement rocks of the Proterozoic eastern granite-rhyolite province and overlying red conglomeratic sandstone (litharenite) of the Proterozoic Middle Run Formation (Drahovzal and others, 1992).

Typical Appalachian thin-skinned structures (terminology of Rodgers, 1963) are bedding-plane detachment zones, footwall ramps, ramp anticlines, and imbricate thrust faults (Rodgers, 1963; Harris and Milici, 1977; Woodward and Gray, 1985). These features are contractional in origin and probably developed during the Late Mississippian to Permian continental collision (Alleghanian orogeny) between eastern North America and Africa (Rodgers, 1988; Hatcher and others, 1989). Crustal contraction that accompanied this collision caused large horizontal displacements of thick, competent panels of Paleozoic strata along surfaces in incompetent Paleozoic strata. In places, the Alleghanian orogeny reactivated basement faults and locally inverted the Rome trough (Harris, 1978; Dever, 1986; Shumaker and Wilson, 1996; Hickman and others, 2006).

\section{Basement Rocks and Associated Structures}

Basement rocks along cross section $I-I^{\prime}$ consist of igneous and metamorphic rocks. East of drill hole 4, these basement rocks are the subsurface extension of the Grenville province (Rankin and others, 1993). Most isotope ages of these Grenville rocks range between 1,350 and 950 million years old (mega-annum, or $\mathrm{Ma}$ ), and many ages cluster around 1,100 to $1,000 \mathrm{Ma}$ (fig. 2). Radiometric ages reported for the majority of basement rocks in the vicinity of cross section $I-I^{\prime}$ are consistent with a Grenville-province age. For example, Heald (1981) reported a potassium-argon (K-Ar) age of $935 \pm 10 \mathrm{Ma}$ for biotite in granodiorite in the No. 
Table 1. Drill holes used in cross section $I-I^{\prime}$.

[Drill-hole locations are shown in figure 1. Sources of lithologic logs are Geological Sample Log Company, Pittsburgh, Pa. (GSLC); W.L. Calvert (1962), Ohio Report of Investigations 45 (C); unpublished data

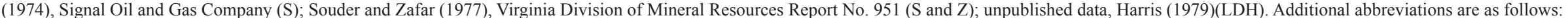
Co., County; Comp., Company; Corp., Corporation; min, minute; NA, not available; No., number; Ky., Kentucky; Va., Virginia]

\begin{tabular}{|c|c|c|c|c|c|c|c|c|c|}
\hline $\begin{array}{l}\text { Drill } \\
\text { hole } \\
\text { number }\end{array}$ & Name used in text & Location & $\begin{array}{c}\text { American } \\
\text { Petroleum } \\
\text { Institute number }\end{array}$ & $\begin{array}{l}\text { Latitude } \\
\text { (decimal } \\
\text { degrees) }\end{array}$ & $\begin{array}{l}\text { Longitude } \\
\text { (decimal } \\
\text { degrees) }\end{array}$ & $\begin{array}{l}\text { Source of } \\
\text { lithologic } \\
\log \end{array}$ & $\begin{array}{l}\text { Cored intervals (in feet) and } \\
\text { stratigraphic unit }\end{array}$ & $\begin{array}{c}\text { Total } \\
\text { depth } \\
\text { (in feet) }\end{array}$ & $\begin{array}{l}\text { Age of oldest } \\
\text { rocks drilled } \\
\text { (stratigraphic unit) }\end{array}$ \\
\hline \multicolumn{10}{|c|}{ Kentucky } \\
\hline 1 & $\begin{array}{l}\text { E.I. Dupont de Nemours and } \\
\text { Comp. No. } 1 \text { Dupont Plant } \\
\text { Disposal }\end{array}$ & $\begin{array}{l}\text { Jefferson Co., Ky. (Louisville West, } \\
\text { Ky., 7.5-min quadangle) }\end{array}$ & $16-111-24576$ & 38.219 & -85.840 & GSLC & $\begin{array}{l}\text { 1,156-1,176, High Bridge Group; } \\
\text { 1,677-1,704, Wells Creek dolomite; } \\
\text { 1,704-1,713, St. Peter Sandstone; } \\
\text { 1,713-1,805, Knox Dolomite; } \\
\text { 2,499-2,529, Copper Ridge Dolomite; } \\
\text { 2,700-2,830, Copper Ridge Dolomite; } \\
\text { 4,410-4,456, Conasauga Formation; } \\
\text { 5,335-5,340, Middle Run Formation; } \\
\text { 5,993-6,008, eastern granite-rhyolite } \\
\text { province gabbro }\end{array}$ & 6,011 & Mesoproterozoic \\
\hline 2 & $\begin{array}{l}\text { Beaver Dam Coal Comp. } \\
\text { No. } 1 \text { C.J. Morris }\end{array}$ & $\begin{array}{l}\text { Shelby Co., Ky. (Shelbyville, Ky., } \\
\text { 7.5-min quadangle) }\end{array}$ & $16-211-09113$ & 38.158 & -85.172 & GSLC & NA & 2,075 & $\begin{array}{l}\text { Late Cambrian } \\
\quad \text { (Copper Ridge } \\
\text { Dolomite) }\end{array}$ \\
\hline 3 & $\begin{array}{l}\text { Stoll Oil and Refining Comp. } \\
\text { No. } 1 \text { Ben Bond }\end{array}$ & $\begin{array}{l}\text { Anderson Co., Ky. (Alton Station, } \\
\text { Ky., 7.5-min quadrangle) }\end{array}$ & $16-005-00000$ & 38.026 & -84.884 & GSLC & NA & 2,838 & $\begin{array}{l}\text { Late Cambrian and } \\
\text { Early Ordovician } \\
\text { (Knox Group) }\end{array}$ \\
\hline 4 & $\begin{array}{l}\text { Phillip Agrios Exploration } \\
\text { No. } 1 \text { Dudley Gaines }\end{array}$ & $\begin{array}{l}\text { Woodford Co., Ky. (Tyrone, Ky., } \\
\text { 7.5-min quadrangle) }\end{array}$ & 16-239-21801 & 38.011 & -84.753 & GSLC & NA & 2,812 & $\begin{array}{l}\text { Late Cambrian and } \\
\text { Early Ordovician } \\
\text { (Knox Group) }\end{array}$ \\
\hline 5 & $\begin{array}{l}\text { Kentucky Drilling and Op- } \\
\text { erating Comp. No. } 1 \text { Paul } \\
\text { Adams and Clarence Long }\end{array}$ & $\begin{array}{l}\text { Clark Co., Ky. (Ford, Ky., 7.5-min } \\
\text { quadrangle) }\end{array}$ & 16-049-10287 & 37.947 & -84.302 & GSLC & NA & 1,563 & $\begin{array}{l}\text { Late Cambrian and } \\
\text { Early Ordovician } \\
\text { (Knox Group) }\end{array}$ \\
\hline 6 & $\begin{array}{l}\text { Ashland Oil and Refining } \\
\text { Comp., Inc. No. } 1 \text { M.W. } \\
\text { Miller }\end{array}$ & $\begin{array}{l}\text { Clark Co., Ky. (Austerlitz, Ky,. } \\
\text { 7.5-min quadrangle) }\end{array}$ & 16-049-18142 & 38.025 & -84.166 & GSLC & NA & 3,425 & Mesoproterozoic \\
\hline 7 & $\begin{array}{l}\text { Ferguson and Bosworth } \\
\text { No. 16-1 Alvery Potter }\end{array}$ & $\begin{array}{l}\text { Montgomery Co., Ky. (Levee, Ky., } \\
\text { 7.5-min quadrangle) }\end{array}$ & $16-173-11507$ & 37.976 & -83.956 & GSLC & NA & 4,481 & Mesoproterozoic \\
\hline 8 & $\begin{array}{l}\text { Monitor Petroleum Corp. } \\
\text { No. } 1 \text { Campbell }\end{array}$ & $\begin{array}{l}\text { Menifee Co., Ky. (Pomeroyton, Ky., } \\
\text { 7.5-min quadrangle) }\end{array}$ & 16-165-29846 & 37.874 & -83.551 & GSLC & $\begin{array}{l}\text { 5,713-5,741, Maryville Limestone of } \\
\text { Conasauga Group }\end{array}$ & 6,787 & Mesoproterozoic \\
\hline 9 & $\begin{array}{l}\text { Monitor Petroleum Corp. } \\
\text { No. } 1 \text { C.K. Stacy Heirs }\end{array}$ & $\begin{array}{l}\text { Morgan Co., Ky. (Cannel City, Ky., } \\
\text { 7.5-min quadrangle) }\end{array}$ & $16-175-28019$ & 37.864 & -83.370 & GSLC & NA & 7,587 & Mesoproterozoic \\
\hline
\end{tabular}


Table 1. Drill holes used in cross section $I-l$..-Continued

[Drill-hole locations are shown in figure 1. Sources of lithologic logs are Geological Sample Log Company, Pittsburgh, Pa. (GSLC); W.L. Calvert (1962), Ohio Report of Investigations 45 (C); unpublished data

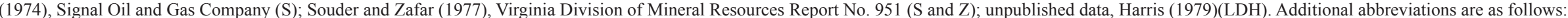
Co., County; Comp., Company; Corp., Corporation; min, minute; NA, not available; No., number; Ky., Kentucky; Va., Virginia]

\begin{tabular}{|c|c|c|c|c|c|c|c|c|c|}
\hline $\begin{array}{l}\text { Drill } \\
\text { hole } \\
\text { number }\end{array}$ & Name used in text & Location & $\begin{array}{c}\text { American } \\
\text { Petroleum } \\
\text { Institute number }\end{array}$ & $\begin{array}{l}\text { Latitude } \\
\text { (decimal } \\
\text { degrees) }\end{array}$ & $\begin{array}{l}\text { Longitude } \\
\text { (decimal } \\
\text { degrees) }\end{array}$ & $\begin{array}{c}\text { Source of } \\
\text { lithologic } \\
\quad \log \end{array}$ & $\begin{array}{l}\text { Cored intervals (in feet) and } \\
\text { stratigraphic unit }\end{array}$ & $\begin{array}{c}\text { Total } \\
\text { depth } \\
\text { (in feet) }\end{array}$ & $\begin{array}{c}\text { Age of oldest } \\
\text { rocks drilled } \\
\text { (stratigraphic unit) }\end{array}$ \\
\hline \multicolumn{10}{|c|}{ Kentucky-Continued } \\
\hline 10 & $\begin{array}{l}\text { Exxon Corp. No. } 1 \text { Orville } \\
\text { Banks }\end{array}$ & $\begin{array}{l}\text { Wolfe Co., Ky. (Lee City, Ky., } \\
\text { 7.5-min quadrangle) }\end{array}$ & $16-237-30520$ & 37.709 & -83.368 & GSLC & $\begin{array}{l}\text { 7,326-7,386, Nolichucky Shale; } \\
\text { 9,425-9,439, Rutledge Limestone; } \\
\text { 12,178-12,186, Chilhowee Group; } \\
\text { 12,188-12,219, Chilhowee Group }\end{array}$ & 12,323 & Mesoproterozoic \\
\hline 11 & $\begin{array}{l}\text { United Fuel Gas Comp. No. } \\
\text { 8613T S.W. (B.) Williams }\end{array}$ & $\begin{array}{l}\text { Breathitt Co., Ky. (Quicksand, Ky., } \\
\text { 7.5-min quadrangle) }\end{array}$ & $16-025-00745$ & 37.537 & -83.290 & GSLC, C & NA & 11,130 & Mesoproterozoic \\
\hline 12 & $\begin{array}{l}\text { Signal Oil and Gas Comp. } \\
\text { No. } 1 \text { Hall }\end{array}$ & $\begin{array}{l}\text { Floyd Co., Ky. (Wayland, Ky., } \\
\text { 7.5-min quadrangle) }\end{array}$ & $16-071-27524$ & 37.493 & -82.758 & $\mathrm{~S}$ & NA & 13,035 & Mesoproterozoic \\
\hline 13 & $\begin{array}{l}\text { Signal Oil and Gas Comp. } \\
\text { No. } 1 \text { Stratton }\end{array}$ & $\begin{array}{l}\text { Pike Co., Ky. (Millard, Ky., 7.5-min } \\
\text { quadrangle) }\end{array}$ & $16-195-24577$ & 37.482 & -82.463 & GSLC & NA & 12,471 & Mesoproterozoic \\
\hline 14 & $\begin{array}{l}\text { United Fuel Gas Comp. No. } \\
201 \text { Kentland Coal and } \\
\text { Coke Comp. }\end{array}$ & $\begin{array}{l}\text { Pike Co., Ky. (Elkhorn City, Ky., } \\
\text { 7.5-min quadrangle) }\end{array}$ & 16-195-18969 & 37.337 & -82.346 & NA & NA & 4,990 & $\begin{array}{l}\text { Middle Devo- } \\
\text { nian (Onondaga } \\
\text { Limestone) } \\
\end{array}$ \\
\hline \multicolumn{10}{|c|}{ Virginia } \\
\hline 15 & $\begin{array}{l}\text { Columbia Natural Resources } \\
\text { No. 20321-T Mullins } \\
\text { Heirs }\end{array}$ & $\begin{array}{l}\text { Dickenson Co., Va. (Elkhorn City, } \\
\text { Va., 7.5-min quadrangle) }\end{array}$ & $45-051-20238$ & 37.278 & -82.259 & GSLC & NA & 9,374 & $\begin{array}{l}\text { Late Cambrian and } \\
\text { Early Ordovician } \\
\text { (Knox Group) }\end{array}$ \\
\hline 16 & $\begin{array}{l}\text { Columbia Gas Transmission } \\
\text { Corp. No. 9781-T Pittston } \\
\text { Comp. }\end{array}$ & $\begin{array}{l}\text { Buchanan Co., Va. (Prater, Va., } \\
\text { 7.5-min quadrangle) }\end{array}$ & $45-027-20147$ & 37.247 & -82.186 & NA & NA & 6,798 & $\begin{array}{l}\text { Ordovician (Juniata } \\
\text { Formation) }\end{array}$ \\
\hline 17 & $\begin{array}{l}\text { Columbia Gas Transmission } \\
\text { Corp. No. 9722-T John W. } \\
\text { Pobst and others }\end{array}$ & $\begin{array}{l}\text { Buchanan Co., Va. (Prater, Va., } \\
\text { 7.5-min quadrangle) }\end{array}$ & $45-027-04032$ & 37.165 & -82.142 & GSLC & NA & 7,299 & $\begin{array}{l}\text { early Silurian } \\
\text { (Hagan Shale } \\
\text { Member of } \\
\text { Clinch Sand- } \\
\text { stone) }\end{array}$ \\
\hline 18 & $\begin{array}{l}\text { Gulf Oil Comp. No. } 1 \text { N.R. } \\
\text { Price }\end{array}$ & $\begin{array}{l}\text { Russell Co., Va. (Hansonville, Va., } \\
\quad 7.5 \text {-min quadrangle) }\end{array}$ & $45-167-20256$ & 36.872 & -82.237 & $\begin{array}{l}\text { GSLC, } \\
\text { LDH }\end{array}$ & $\begin{array}{l}\text { 8,735-8,739, Clinch Sandstone; } \\
\text { 9,710-9,770, Trenton Limestone; } \\
\text { 13,400-13,420, Copper Ridge Dolo- } \\
\text { mite of Knox Group }\end{array}$ & 17,000 & Mesoproterozoic \\
\hline 19 & $\begin{array}{l}\text { Tidewater and Wolf's Head } \\
\text { No. } 1 \text { E.D. Smith }\end{array}$ & $\begin{array}{l}\text { Scott Co., Va. (Mendota, Va., } \\
\text { 7.5-min quadrangle) }\end{array}$ & 45-169-19690 & 36.649 & -82.318 & $\begin{array}{l}\text { GSLC, } S \\
\text { and } Z\end{array}$ & $\begin{array}{l}\text { 3,243-3,253, Little Valley Limestone; } \\
\text { 6,991-6,998, Clinch Sandstone }\end{array}$ & 7,222 & $\begin{array}{l}\text { Late Ordovician } \\
\text { (Sequatchie } \\
\text { Formation) }\end{array}$ \\
\hline
\end{tabular}


9674T Mineral Tract well, located in Mingo County, West Virginia, about 33 mi northeast of drill hole 13 in cross section $I-I^{\prime}$ (fig. 1). Keller and others (1981) reported K-Ar biotite ages of $894 \pm 30 \mathrm{Ma}$ (depth of $7,586 \mathrm{ft}$ ) and $917 \pm 31 \mathrm{Ma}$ (depth of 6,388 ft) in the No. 1 Blanton well, located in Morgan County, Kentucky, about $7 \mathrm{mi}$ northeast of drill hole 8 in cross section $I-I^{\prime}$ (fig. 1). Keller and others (1981) also reported rubidium-strontium ( $\mathrm{Rb}-\mathrm{Sr}$ ) ages of $975 \pm 85 \mathrm{Ma}$ (from feldspar in a microsyenite vein) in the No.1 Daulton well, and $950 \pm 40 \mathrm{Ma}$ (from biotite in gneiss) in the No. 1 Edwards well, both of which are located in Pulaski County, Kentucky, approximately $60 \mathrm{mi}$ southwest of drill hole 5. Hoppe and others (1983) and Randy Van Schmus (Steve Bergman, oral commun., 1992) reported an older zircon uranium-lead (U-Pb) age of 1,457 \pm 10 Ma for syenite in the No. 1 Edwards well. This older $\mathrm{U}-\mathrm{Pb}$ age possibly represents the age of a protolith to the metamorphic rocks of the Grenville province. Although some of these reported ages are older than Mesoproterozoic, or younger than the 950 Ma Mesoproterozoic basement lower limit suggested by Rankin and others (1993), the rocks with ages of approximately 1,457 to $894 \mathrm{Ma}$ are grouped in this report with rocks of the Grenville province based on their similar lithology and structural style.

The western margin of the subsurface extension of the Grenville province is marked by the Grenville front (figs. 1 and 2), along which intensely deformed Grenville-age (Mesoproterozoic) metamorphic and igneous rocks (commonly characterized by westverging thrust faults; Culotta and others, 1990; Rankin and others, 1991; Drahovzal and others, 1992) are juxtaposed against mildly deformed 1,480 to 1,450 Ma crystalline basement rocks of the eastern granite-rhyolite province to the west (Lidiak and others, 1993; Van Schmus and others, 1996; McBride and others, 2001). The basement-involved Lexington fault zone, located between drill holes 4 and 5 (fig. 1), defines the approximate boundary between Grenville Mesoproterozoic basement rocks and rocks of the eastern granite-rhyolite province (Drahovzal and others, 1992). Drill hole 1 in Jefferson County, Kentucky, is the only drill hole along cross section $I-I^{\prime}$ that bottomed in crystalline rocks of the eastern granite-rhyolite province (fig. 1). Gabbro at the bottom of this drill hole has been interpreted as basement rock of the eastern granite-rhyolite province (Drahovzal and others, 1992) from a determined Rb-Sr isotope age of 1,500 $\pm 200 \mathrm{Ma}$ (Steve Bergman, ARCO Exploration and Production, written commun., 1993). An alternate interpretation is that the gabbro in drill hole 1 originated as a Mesoproterozoic feeder dike system that was emplaced along the faulted margin of the Louisville Accommodation Structure (fig. 1) and was composed of crystalline basement rocks of the eastern granite-rhyolite province (Stark, 1997a).

Mesoproterozoic basement rocks along the Grenville front have been thrust west against the Proterozoic Middle Run Formation, which overlies an unconformity on basement rocks of the eastern graniterhyolite province. Evidence for westward thrusting of Grenville basement rocks against rocks of the Proterozoic Middle Run Formation is from the No. 1 Sherrer well (Jessamine County, Kentucky), approximately 17 mi southeast of drill hole 4 (fig. 1) and within a mile of the Grenville front. In core from this well, the Middle Run Formation dips as steep as 70 degrees (J.A. Drahovzal, written commun., 2010). Moreover, weathered basalt is present at the top of the Middle Run Formation in the No. 1 Sherrer well (M.N. Bass, written commun., 1970), but the structural context of the basalt is unknown. Presumably, both the basalt and the red conglomeratic sandstone (litharenite) units of the Middle Run Formation were deformed by contraction associated with the Grenville front (J.A. Drahovzal, written commun., 2010). J.A. Drahovzal (written commun., 2010) estimated that the age of the Middle Run Formation in the No. 1 Sherrer well is about 1,000 Ma. The 1,020 Ma radiometric age of a quartz trachyte (or rhyolite) flow within the Middle Run Formation in the
No. 1 Spears well in Lincoln County, Kentucky (M.N. Bass, written communication to the Kentucky Geological Survey, 1969; Drahovzal and others, 1992) is consistent with the 1,000 Ma age of deposition of the Middle Run Formation proposed by J.A. Drahovzal (written commun., 2010).

The crystalline basement of the Appalachian basin is a homoclinal ramp that dips gently from an interior craton to the external margin of a fold-and-thrust belt, which is typical of many foreland basins. Along cross section $I-I^{\prime}$, this basement ramp deepens progressively to the southeast from about 2,200 ft below mean sea level (MSL) beneath the Cincinnati arch near drill hole 4, to about 14,000 ft below MSL beneath the Allegheny structural front at drill hole 18. This gradual eastward deepening of the basement ramp along cross section $I-I^{\prime}$ is interrupted by the Rome trough, a Middle Cambrian rift system that drops the basement rocks to as much as 12,000 ft below MSL (fig. 1). The northwestern limit of the Rome trough on cross section $I-I^{\prime}$ is defined as the down-to-the-south Kentucky River fault, which is located several miles northwest of drill hole 7 , whereas the eastern limit of the Rome trough on cross section $I-I^{\prime}$ is defined as the down-to-the-west Rockcastle River fault, which is located about $8 \mathrm{mi}$ southeast of drill hole 11 (Drahovzal and Noger, 1995; Shumaker, 1996; Hickman and others, 2006). Along cross section $I-I^{\prime}$, the Rome trough is about $65 \mathrm{mi}$ wide and has a structural relief on the top of basement that ranges from about 1,000 ft at its western margin to an estimated 3,800 $\mathrm{ft}$ along the Irvine-Paint Creek fault in the middle of the trough. In general, the structural relief on basement along the Rome trough in cross section $I-I^{\prime}$ is less than the structural relief on basement along the margins and (or) within the Rome trough in cross sections $C-C^{\prime}$ and $D-D^{\prime}$. This decrease in structural relief in cross section $I-I^{\prime}$ may represent less crustal extension during the Mesoproterozoic in central and eastern Kentucky than in southwestern Pennsylvania and northern West Virginia. 
Many of the normal (extensional) faults associated with the Rome trough rift system were reactivated at least once during the Paleozoic to produce either renewed subsidence or small-scale basin inversion (Shumaker and Wilson, 1996). The best example of basin inversion on cross section $I-I^{\prime}$ is shown by the Caney anticline on the southern side of the Irvine-Paint Creek fault between drill holes 9 and 10. This deeply rooted anticline probably resulted from a reversal in motion of the preexisting, down-to-south Irvine-Paint Creek fault in the middle of the Rome trough (Sable, 1978; Hickman and others, 2006). The reversal in motion that caused the small-scale inversion probably resulted from contraction during the Late Mississippian to Permian Alleghanian orogeny.

The southeast-dipping basement block between the Rockcastle River fault and the Allegheny structural front along cross section $I-I^{\prime}$ is an extension of the central West Virginia and southern West Virginia arches (fig. 1) that were identified by Kulander and Dean (1986). This southeast-dipping block is broken along several north- to northwest-trending subvertical basement faults (with as much as 500 to $1,000 \mathrm{ft}$ of vertical separation) that divide the block into the Perry and Pike County uplifts (between drill holes 11 and 13) and the intervening Floyd County embayment at drill hole 12 (Sutton, 1981). The D'Invilliers structure, located between drill holes 14 and 15, is a northeast-trending flexure that is probably underlain by a basement fault that bounds the eastern side of the Pike County uplift (Kubik, 1993; Drahovzal and Noger, 1995; Shumaker, 1996). Therefore, the Perry and Pike County uplifts and the Floyd County embayment are probably fault-bound blocks that trend approximately normal to the Rome trough and terminate against the southern margin of the Rome trough (fig. 1). The southern ends of these fault blocks are overridden by the Pine Mountain thrust fault (fig. 1).

Paleozoic strata along the western flank of the Cincinnati arch dip west into the Illinois basin at a much lower angle than the Paleozoic strata dipping off the eastern flank of the dome. The westward dip of strata from the Cincinnati arch into the Illinois basin is generally very uniform except for several minor sags, low-amplitude anticlines and synclines, terraces, monoclines, and fault zones (Cressman, 1965; Kepferle, 1974a; Black, 1989). Most of these subtle surface structures are probably underlain by Proterozoic- to Cambrian-age extensional basement faults, similar to faults that have been interpreted in nearby areas by Drahovza and others (1992) and Stark (1997a,b). Many basement faults of Proterozoic to Cambrian age in the Illinois basin and vicinity were reactivated during the Late Mississippian to Permian Ouachita and (or) Alleghanian orogenies (Kolata and Nelson, 1997), creating minor structures in the overlying strata. In addition, two circular-shaped cryptoexplosive structures are located along the western flank of the Cincinnati arch near cross section $I-I^{\prime}$. The larger and more complex of the two is the Jeptha Knob structure (Cressman, 1975a,b; Black, 1989), which is located about 3 mi northeast of drill hole 2, whereas the smaller Versailles structure (Black, 1964; Black, 1989) is located about 7 mi northeast of drill hole 3. Cressman (1981) and Seeger and others (1985) have attributed the origin of the Jeptha Knob structure to a meteorite impact, although shatter cones and meteorites have not been found in this area.

\section{Thin-Skinned Structures}

Thin-skinned structures in the Valley and Ridge province of cross section $I-I^{\prime}$ are dominated by a system of foreland-vergent thrust faults (terminology of McClay, 1992) that consists from northwest to southeast of the Pine Mountain, St. Paul (Hunter Valley), Dumps, Honaker, and Copper Creek thrust faults (Rodgers, 1970; Harris and Milici, 1977; Woodward and Gray, 1985; Mitra, 1988; Evans and Troensegaard, 1991). In addition, the Saltville thrust fault (fig. 1) is located several miles beyond the south end of cross section $I-I^{\prime}$ (Bartlett and Webb, 1971; Virginia Division of Mineral Resources, 1993). As noted by Milici (1980) and shown on cross section $I-I^{\prime}$, this belt of predominantly foreland-vergent, thin thrust sheets in the Valley and Ridge province contrasts in deformational style with the belt of thick thrust sheets and high-amplitude anticlines located along strike to the northeast (shown by cross sections $C-C^{\prime}, D-D^{\prime}$, and $E-E^{\prime}$ ). The only anticline of the Valley and Ridge province shown on cross section $I-I^{\prime}$ is the previously mentioned unnamed ramp anticline that is penetrated by well 18 (fig. 3) and is concealed beneath the St. Paul (Hunter Valley), Dumps, and Honaker thrust faults.

The Pine Mountain thrust fault (Alvord and Miller, 1972) and the associated Pine Mountain anticline immediately to the southeast (not shown on fig. 1) (Henika, 1989, 1994) crop out along cross section $I-I^{\prime}$ between drill holes 14 and 15 and define the leading edge of the foreland-vergent group of thrust faults (fig. 1). This part of the Pine Mountain thrust fault represents a northeast extension of the main branch of the thrust fault at its juncture with the Russell Fork fault (Alvord and Miller, 1972). The Pine Mountain thrust fault (extension) places Pennsylvanian strata on the hanging wall against Pennsylvanian strata on the footwall with about $500 \mathrm{ft}$ of vertical separation (Alvord and Miller, 1972). In contrast, the main branch of the Pine Mountain thrust fault places Upper Devonian strata on the hanging wall against Pennsylvanian strata on the footwall with about 3,000 to $5,000 \mathrm{ft}$ of vertical separation (Harris and Milici, 1977; Woodward and Gray, 1985; Mitra, 1988). The Pine Mountain thrust fault (extension) shown on cross section $I-I^{\prime}$ continues downward as a southeast-dipping (20 to 30 degrees) secondary footwall ramp to a depth of about $5,500 \mathrm{ft}$ where the fault flattens into the upper detachment zone (hangingwall flat of the primary footwall ramp) in the Devonian Marcellus Shale and (or) Rhinestreet Shale Member of the West Falls Formation (fig. 3). This 
upper detachment zone (hangingwall flat) in the Pine Mountain thrust fault continues within the Marcellus and Rhinestreet Shales to the south for about $32 \mathrm{mi}$ to a depth of about 8,000 ft where the detachment joins the primary footwall ramp of the Pine Mountain thrust fault near drill hole 18 (fig. 3). The primary footwall ramp of the Pine Mountain thrust fault dips about 30 to 40 degrees to the southeast, cuts across Cambrian through Middle Devonian strata to a depth of about $16,500 \mathrm{ft}$, and then flattens into the basal detachment zone (footwall flat of the primary footwall ramp) in the Lower Cambrian Shady Dolomite (fig. 3).

As previously mentioned, the unnamed anticline penetrated by well 18 is interpreted as a ramp (fault-bend) anticline that formed in a thick panel of Cambrian and Ordovician rocks. These strata were transported to the northwest up and over the primary footwall ramp that connected the basal detachment zone in Cambrian strata (footwall flat of the primary footwall ramp) with the upper detachment (hangingwall flat of the primary footwall ramp) in Devonian shale (fig. 3). The lower 2,500 $\mathrm{ft}$ of the anticlinal core is interpreted here as a duplex composed of stacked thrust slices (horse blocks) of Shady Dolomite and Rome Formation (fig. 3). These horse blocks probably were detached from the adjoining footwall ramp, as were similar horse blocks described by Schultz (1988) in the Pulaski thrust sheet in Montgomery, Pulaski, and Wythe Counties, Virginia. The duplex (antiformal stack) of Shady and Rome thrust slices and the overlying Cambrian carbonate rocks formed a tectonic wedge that was inserted into the slip-prone Devonian shale along the upper detachment zone of the Pine Mountain thrust fault. As the wedge-shaped leading edge of the ramp anticline was driven by contraction into the Devonian shale, a thick flap of the overlying Devonian and Mississippian rocks was progressively steepened to form a passive roof duplex (terminology of McClay, 1992) above the northwest limb of the anticline. Although both the unnamed ramp anticline and the Powell Valley anticline (fig. 1) are situated along the primary footwall ramp of the Pine Mountain thrust sheet, they represent slightly different styles of thin-skinned deformation and degrees of net shortening. For example, the core of the unnamed ramp anticline contains the previously described stack of thin thrust slices (horse blocks) with about 6 to $7 \mathrm{mi}$ of net shortening, whereas the core of the Powell Valley anticline contains one or two thicker thrust slices with about 12 to $14 \mathrm{mi}$ of net shortening (Harris and Milici, 1977).

In this report, the unnamed ramp anticline (fig. 3) is interpreted as occupying the same geometric position as a ramp anticline that Woodward and Gray (1985, cross section 19) shows at the top of the primary footwall ramp of the Pine Mountain thrust fault and beneath the St. Paul (Hunter Valley) thrust fault, although the ramp anticline of Woodward and Gray (1985) is not shown as a duplex. In contrast, an alternative interpretation by Evans and Troensegaard (1991) shows an allochthonous, primarily unfaulted, southeast-dipping homocline of lower Paleozoic strata.

The Copper Creek thrust fault branches off the basal detachment zone in the Lower Cambrian Shady Dolomite about 9 mi to the southeast of the primary footwall ramp of the Pine Mountain thrust fault and crops out about $3 \mathrm{mi}$ to the southeast of the unnamed ramp anticline where the Rome Formation in the hanging wall is juxtaposed against Middle and Upper Ordovician limestone in the footwall. The Copper Creek thrust fault sheet shown on cross section $I-I^{\prime}$ is a 14,000 - to 15,000 -ft-thick panel of Paleozoic strata that dips to the southeast beneath the Saltville thrust fault, which is located within $5 \mathrm{mi}$ of the southern end of the cross section (fig. 1). About 7,000 ft of Silurian, Devonian, and Mississippian strata in the upper part of the Copper Creek thrust fault sheet were penetrated by well 19. The Mississippian strata penetrated by well 19 form the upright, northwest flank of the overturned Greendale syncline beneath the Saltville thrust fault (Cooper, 1966; Bartlett and Webb, 1971). Restored cross section
19 in Woodward and Gray (1985) indicates that the main branch of the Pine Mountain thrust fault and the Copper Creek thrust fault represent about 35 to $40 \mathrm{mi}$ of total lateral shortening (or about 45 percent lateral shortening). By comparison, Kulander and Dean (1986) calculated 52 percent structural shortening across approximately the same region, using cross section 13 of their report.

In cross section $I-I^{\prime}$, the St. Paul (Hunter Valley), Honaker, and Dumps thrust faults are interpreted as frontal imbricates off the Copper Creek thrust fault that truncate the crest of the unnamed ramp anticline and conceal it beneath 2,500 ft of displaced strata. Woodward and Gray (1985) provide an alternative interpretation, which shows these faults as branches of the basal detachment. Another alternative interpretation is provided by Mitra (1988), who showed the St. Paul (Hunter Valley) thrust fault and Clinchport thrust fault (roughly equivalent to the Honaker thrust fault) as imbricates off a shallower fault system that presumably connects with the deeper Copper Creek thrust fault.

\section{Stratigraphic Framework}

Mesoproterozoic and Neoproterozoic(?) sedimentary rocks of the Middle Run Formation are present on cross section $I-I^{\prime}$ from near the western end of the section to the Lexington fault (about midway between drill holes 4 and 5). Across the entire length of cross section $I-I^{\prime}$, these Mesoproterozoic and Neoproterozoic(?) sedimentary rocks (and crystalline basement rocks of the adjoining Grenville and eastern granite-rhyolite provinces) are overlain by Paleozoic sedimentary rocks of thicknesses ranging from about $6,000 \mathrm{ft}$ on the easternmost flank of the Illinois basin to about 3,000 $\mathrm{ft}$ along the crest of the Cincinnati arch and to about $16,000 \mathrm{ft}$ near the Allegheny structural front. The lithology, stratigraphic nomenclature, depositional settings, 
and tectonic settings of the Mesoproterozoic, Neoproterozoic(?), and Paleozoic sedimentary rocks along cross section $I-I^{\prime}$ are briefly outlined and discussed in the following text. More detailed discussions are available in regional geological summaries by Colton (1970), Milici and de Witt (1988), Read (1989a,b), and Ettensohn (1992a).

Much of the eastward thickening of strata in the Appalachian basin was caused by regional tectonic events. For example, during the Neoproterozoic to Early Cambrian, as the proto-Atlantic (Iapetus) Ocean opened and formed a rifted continental margin, cooling and thermal contraction of the lithosphere caused subsidence that provided accommodation or preservation space for sediments to build an east-facing passive continental margin (Bond and others, 1988; Read, 1989b). During several later periods of the Paleozoic, subsidence caused by thrust loading provided additional accommodation or preservation space for sediments to accumulate in Appalachian foreland basins (Quinlan and Beaumont, 1984). Sea level changes, caused by changes in global climate and (or) changes in regional tectonic activity, also played a role in the eastward thickening of Appalachian strata (Bond and others, 1988). For example, a rise in sea level may cause load-induced subsidence (by sediment and water column overburden) and provide accommodation space for additional sediments on the outer continental shelf, whereas a fall in sea level may cause erosion of the inner continental shelf.

During the Paleozoic, the Cincinnati arch behaved as a relatively stable block supported by the thick, rigid Middle Run Formation and adjoining crystalline rocks of the Grenville front. Stark (1997a) also recognized the close alignment of the axis of the Cincinnati arch and the subcrop of the Middle Run Formation but offered no explanation for the association of these features. Westward thickening of Paleozoic strata from the Cincinnati arch into the Illinois basin probably had multiple causes, one of which was extensional faulting of the basement and associated graben systems in western Kentucky and Illinois (Kolata and Nelson, 1997; Noger and Drahovzal, 2005). Subsidence was probably initiated during the Middle to Late Cambrian and persisted throughout most of the Paleozoic (Thomas, 1991; Kolata and Nelson, 1997).

\section{Mesoproterozoic to Neoproterozoic(?) Siliciclastic Strata}

Mesoproterozoic crystalline rocks of the eastern granite-rhyolite province are capped by an unconformity, above which lie relatively flat-lying siliciclastic red beds of the Proterozoic Middle Run Formation. The siliciclastic red beds of the Middle Run Formation are characterized by red conglomeratic sandstone (litharenite), red to reddish-gray sandstone (litharenite), pebbly sandstone, siltstone, and local shale (fig. 2). Framework grains consist of quartz, feldspar (mostly potassium feldspar), and rock fragments that are mostly of metamorphic and volcanic origin (Shrake and others, 1990; Richard and others, 1997). The eastern limit of the Middle Run Formation on cross section $I-I^{\prime}$ is marked by the Grenville structural front, where Mesoproterozoic crystalline rocks of the Grenville province are placed in thrust contact against the Middle Run Formation (Drahovzal and others, 1992; Stark, 1997a,b). However, an alternate interpretation by Richard and others (1997), which is based on seismic data in southern Ohio, suggests that the Middle Run Formation overlaps rocks of the Grenville province and thus is a post-Grenville deposit. Although the estimated thickness of the Middle Run Formation is speculative because few wells have penetrated the unit, Drahovzal and others (1992) estimated the thickness in the vicinity of cross section $I-I^{\prime}$ to range from 15,000 to $20,000 \mathrm{ft}$.

The Middle Run Formation was named by Shrake and others $(1990,1991)$ for a 1,910-ft-thick pre-Mount Simon unit penetrated in an Ohio Geological Survey corehole in Warren County, Ohio, (fig.1) and to which they assigned a late Precambrian age. Richard and others (1997), however, considered the Middle Run Formation to be Early Cambrian in age, and thus younger than the 1.1 Ga Midcontinent Rift System. Uranium-lead (U-Pb) ages (84 analyses) of Middle Run Formation detrital zircons from the corehole in Warren County, Ohio, range from 1,982 to $1,030 \mathrm{Ma}$ and indicate that most, but not all, of the zircons at the top of the Middle Run Formation were derived from the Grenville province (Santos and others, 2002). A U-Pb age of $1,048 \pm 22 \mathrm{Ma}$ for the youngest of a population of 61 detrital zircons indicates that the Middle Run Formation is a late Grenville to post-Grenville deposit (Santos and others, 2002). On the basis of zircon fission track dating by Roden-Tice and Shrake (1998), an upper age limit of 700 to $600 \mathrm{Ma}$ for the Middle Run Formation suggests that the unit is a post-Grenville deposit. The apparent absence of detrital zircons younger than 1.0 Ga in the Middle Run Formation may have been caused by the lack of felsic volcanism during the early Neoproterozoic (Santos and others, 2002).

There is some debate about the configuration of the rocks of the Grenville province, the eastern graniterhyolite province, and the Middle Run Formation and, consequently, the Mesoproterozoic and Neoproterozoic history of central Kentucky and adjoining States. The detrital zircon geochronology study by Santos and others (2002), combined with seismic data presented by Richard and others (1997) and Baranoski and others (2009), strongly suggest that at least the upper part of the Middle Run Formation in central and southern Ohio is a post-Grenville foreland basin deposit. In contrast, however, the previously described steeply dipping beds of the Middle Run Formation in the No. 1 Sherrer well suggest that the Middle Run Formation in the vicinity of cross section $I-I^{\prime}$ was deposited prior to the thrust emplacement of Grenville province rocks along the Grenville front (Drahovzal and others, 1992; Stark, 1997a,b). 
The Middle Run Formation is interpreted as a braided fluvial deposit that accumulated on a semiarid alluvial plain (Richard and others, 1997). However, the origin of the basin in which the Middle Run Formation was deposited is uncertain. The Middle Run Formation may represent either synorogenic to early post-orogenic deposits of a 1.3 to $1.0 \mathrm{Ga}$ foreland basin (Hauser, 1993; Santos and others, 2002) or $1.1 \mathrm{Ga}$ rift basin deposits of the East Continent Rift basin (Cannon and others, 1989) approximately coeval with the Midcontinent Rift System (Drahovzal and others, 1992). More recently, on the basis of interpretations of regional seismic reflection profiles, Baranoski and others (2009) suggested that the Middle Run Formation accumulated in both types of basins: the lower part of the Middle Run Formation accumulated in the East Continent Rift basin (extensional phase), whereas the upper part of the Middle Run Formation accumulated in the Grenville foreland basin (contractional phase). According to Baranoski and others (2009), both the extensional and contractional phases resulted from separate stages of Grenville orogenesis. Foreland basin deposits would have been primarily derived from a Grenville province terrane, whereas rift basin deposits would likely have been derived from both the Grenville province and eastern granite-rhyolite province terranes. Both types of basins are consistent with a thrust contact between the Middle Run Formation and Grenville-province basement rocks.

\section{Lower Cambrian to Upper Ordovician Siliciclastic and Carbonate Strata}

The Middle Run Formation is capped by an unconformity, above which lies Lower Cambrian to Upper Ordovician siliciclastic and carbonate strata that consist predominantly of limestone, dolomite, and gray shale, and lesser amounts of sandstone, anhydritic dolomite, and red shale (fig. 2). The thickest section of Lower Cambrian to Upper Ordovician siliciclastic and carbonate strata on cross section $I-I^{\prime}$ is located in the central part of the Rome trough between the IrvinePaint Creek fault and drill hole 10. At this location, the Lower Cambrian to Upper Ordovician strata are about $10,000 \mathrm{ft}$ thick. To the north across the Irvine-Paint Creek fault, the Lower Cambrian to Upper Ordovician strata thin abruptly across several underlying basement fault blocks to about 4,000 to 4,500 $\mathrm{ft}$ in the northern part of the Rome trough near drill hole 7 and the Lexington fault zone. As shown on $I-I^{\prime}$, Lower Cambrian to Upper Ordovician strata continue to thin westward from the northern margin of the Rome trough to a thickness of about 3,200 ft near the crest of the Cincinnati arch between drill holes 4 and 5. West of the Cincinnati arch, Lower Cambrian to Upper Ordovician strata gradually thicken to about $4,200 \mathrm{ft}$ in the easternmost part of the Illinois basin at drill hole 1 . Near the southern limit of the Rome trough at the Rockcastle River fault, the Lower Cambrian to Upper Ordovician strata are estimated to be about 8,500 ft thick. Between the Rockcastle River and Irvine-Paint Creek fault zones, the block-faulted central depocenter of the Rome trough contains two horst blocks over which Lower Cambrian and Upper Ordovician strata are about 9,400 $\mathrm{ft}$ thick and 7,800 ft thick in drill holes 10 and 11, respectively. Southeast of the Rome trough (across the basement-involved fault blocks of the Perry County uplift, Floyd County embayment, and Pike County uplift), the thickness of Lower Cambrian to Upper Ordovician strata varies from about 7,300 to 8,500 $\mathrm{ft}$ from west to east across the Perry County uplift to about 8,500 to 9,000 $\mathrm{ft}$ in the Floyd County embayment (drill hole 12) to about 6,700 to 7,000 ft across the Pike County uplift (drill hole 13). The autochthonous, gently southeast-dipping section of Lower Cambrian to Upper Ordovician siliciclastic and carbonate strata thickens slightly from a $6,700 \mathrm{ft}$ section in drill hole 13 to about 7,000 $\mathrm{ft}$ in the primary footwall ramp of the Pine Mountain thrust fault (drill hole 18). By comparison, the allochthonous Lower Cambrian and Upper Ordovician strata in the Copper Creek thrust sheet at the southeastern end of cross section $I-I^{\prime}$ varies in thickness from about 7,500 to $8,000 \mathrm{ft}$.

In the southeastern part of cross section $I-I^{\prime}$ from the Rome trough to the Pike County uplift, Lower Cambrian to Lower Ordovician siliciclastic and carbonate strata are capped by the regional Middle Ordovician unconformity (Knox unconformity), above which lie Middle and Upper Ordovician strata that are predominantly carbonate. Below the Knox unconformity, these strata consist of the following units (in ascending order): (1) the Chilhowee Group; (2) the Shady Dolomite; (3) the Rome Formation; (4) the Conasauga Group, which is subdivided into the Pumpkin Valley Shale, the Rutledge Limestone, the Rogersville Shale, the Maryville Limestone, the Nolichucky Shale, and the Maynardville Limestone; and (5) the Knox Group, which is subdivided into the Copper Ridge Dolomite, the Rose Run Sandstone, and the Beekmantown Dolomite (fig. 2). Above the Knox unconformity, the Ordovician strata consist of the following units (in ascending order): (1) the St. Peter Sandstone; (2) the Wells Creek dolomite; (3) the High Bridge Group; and (4) the Lexington Limestone (fig. 2). The Chilhowee Group, Shady Dolomite, Rome Formation, and Conasauga Group thin progressively to the northwest and terminate against successively higher fault blocks (such as those defined by the Irvine-Paint Creek and Kentucky River faults) so that beyond the northwestern margin of the Rome trough only the uppermost Middle Cambrian to Upper Ordovician part of the siliciclastic and carbonate unit is present on cross section $I-I^{\prime}$.

On the east flank of the Cincinnati arch between the Kentucky River and Lexington fault zones (drill hole 5 and 6), the Middle Cambrian to Lower Ordovician strata are also capped by the regional Middle Ordovician unconformity (Knox unconformity), above which lie Middle and Upper Ordovician strata that are predominantly carbonate. Below the Knox unconformity, these strata consists of the following units (in ascending order): (1) the Mount Simon Sandstone, which is probably equivalent to the upper part of the 
Maryville Limestone; (2) the Conasauga Formation, which is equivalent to the Nolichucky Shale; (3) the Knox Group, which is subdivided into the Copper Ridge Dolomite, the Rose Run Sandstone, and the Beekmantown Dolomite (fig. 2). Above the Knox unconformity, the Ordovician strata consist of the following units (in ascending order): (1) the St. Peter Sandstone, which is probably present between drill holes 6 and 7; (2) the Wells Creek dolomite; (3) the High Bridge Group; and (4) the Lexington Limestone (fig. 2).

Farther west, between the crest and western flank of the Cincinnati arch and the eastern flank of the Illinois basin (drill holes 1 through 4), Middle Cambrian to Lower Ordovician strata are capped by the regional Middle Ordovician unconformity (Knox unconformity), above which lie Middle and Upper Ordovician strata that are predominantly carbonate. Below the Knox unconformity, these strata consist of the following units (in ascending order): (1) the Mount Simon Sandstone; (2) the Eau Claire Formation, which includes strata equivalent to the Conasauga Formation and the Maynardville Limestone; and (3) the Knox Group, which is subdivided into the Copper Ridge Dolomite, the Rose Run Sandstone, and the Beekmantown Dolomite (fig. 2). Above the Knox unconformity, the Ordovician strata consist of the following units (in ascending order): (1) the St. Peter Sandstone; (2) the Wells Creek dolomite; (3) the High Bridge Group; (4) the Lexington Limestone; (5) the "Utica shale;" (6) the Maquoketa Shale; (7) the Calloway Creek Limestone; (8) the Grant Lake Limestone; and (9) the Drakes Formation (fig. 2).

In the Cumberland Plateau of southwestern Virginia, between the Kentucky-Virginia border (between drill holes 14 and 15) and drill hole 18, the Rose Run Sandstone is replaced by the Chepultepec Dolomite, and the Beekmantown Dolomite is replaced by the Kingsport Formation and Mascot Dolomite (fig. 2). New nomenclature is used in cross section $I-I^{\prime}$ for strata that are equivalent to the St. Peter Sandstone, Wells Creek dolomite, High Bridge Group, and
Lexington Limestone south of the Kentucky-Virginia border. In this area, the stratigraphic nomenclature changes as follows: (1) the St. Peter Sandstone and Wells Creek dolomite are replaced by a unit of red shale, gray shale, shaly dolomite, and limestone that is named the Blackford Formation, and an overlying carbonate unit that consists of the Elway, Five Oaks, and Lincolnshire Limestones; (2) the High Bridge Group is replaced by a sequence of local limestone units that are named the Rockdell Limestone, Benbolt, Wardell, and Bowen Formations, and the overlying Witten and Eggleston Limestones; and (3) the Lexington Limestone is replaced by the Trenton Limestone (fig. 2). There are additional changes in nomenclature for allochthonous Lower Cambrian and Upper Ordovician strata in the Valley and Ridge province of southwestern Virginia. For example, between drill holes 18 and 19 the lower part of the Conasauga Group (Pumpkin Valley Shale, Rutledge Limestone, Rogersville Shale, and Maryville Limestone) changes facies to a mostly dolomitic unit that is named the Honaker Formation (fig. 2). Furthermore, local units that constitute the Blackford Formation through the Trenton Limestone Formation are mapped in the Valley and Ridge part of cross section $I-I^{\prime}$ as a single unit, which is identified as Middle and Upper Ordovician limestone.

On cross section $I-I^{\prime}$, crystalline basement rocks of the Grenville province are capped by an unconformity, above which lies a sandstone ("basal sandstone") that is named the Lower Cambrian Chilhowee Group (Webb, 1980; Read, 1989a,b; Hickman and others, 2004; Hickman and others, 2006; Ryder, Swezey, and others, 2008). The use of the term "Chilhowee Group" in this report follows Kulander and Dean (1986), who correlated the basal sandstone in the Paleozoic section with outcrops of the Chilhowee Group in southwestern Virginia along the Blue Ridge structural front (fig. 1). Where the Chilhowee Group (basal sandstone) is penetrated by drill holes 10 through 13 and drill hole 18 in cross section $I-I^{\prime}$, the unit ranges in thickness from about 50 to $150 \mathrm{ft}$. The basal sandstone in these drill holes consists of very fine to coarse-grained arkosic sandstone interbedded with minor red shale. Along cross section $I-I^{\prime}$, the basal sandstone extends to the northwest as far as the Irvine-Paint Creek fault. On the basis of outcrop studies in southwestern Virginia, the basal sandstone of the Chilhowee Group in cross section $I-I^{\prime}$ is interpreted as a shallow-marine deposit with a cratonic sediment source to the west (Schwab, 1986; Simpson and Eriksson (1990).

The basal sandstone of the Chilhowee Group is overlain by a unit of primarily dolomite and shale that is mapped as the Lower Cambrian Shady Dolomite. The Early Cambrian age of the Shady Dolomite is based on the presence of the fossil Salterella in outcrop and drill core in Wythe County, southwestern Virginia (Byrd and others, 1973; Willoughby, 1976). Where the Shady Dolomite is penetrated by drill holes 10 through 13 and drill hole 18, the unit has a thickness of about 100 to $250 \mathrm{ft}$. In drill holes 10 through 13, the Shady Dolomite consists of finely crystalline dolomite as much as $40 \mathrm{ft}$ thick interbedded with grayish-green shale and local beds of red shale, sandstone, and siltstone. In the autochthonous part of drill hole 18, the Shady Dolomite consists of finely crystalline dolomite as much as 50- to 60-ft-thick, anhydritic dolomite, anhydrite, greenish-gray shale, and siltstone (L.D. Harris, unpub. data, 1979). The previously discussed thrus slices (horse blocks) in drill hole 18 (6,792 to 7,457 ft) that were interpreted by L.D. Harris to be Shady Dolomite (written communication to J.A. Cramer, Jr., 1979) consist of dolomite, anhydrite, anhydritic dolomite, and minor red shale. Along cross section $I-I^{\prime}$, the Shady

Dolomite extends to the northwest as far as an unnamed fault about $10 \mathrm{mi}$ southeast of the northwestern margin of the Rome trough.

The carbonate strata of the Shady Dolomite that overlie the Chilhowee Group are interpreted as a transgressive marine deposit that accumulated on a marine shelf and carbonate ramp after the adjacent craton was submerged by the Iapetus Ocean (Read, 1989a,b). The Shady Dolomite described in both the autochthonous 
footwall and the allochthonous horse blocks penetrated in drill hole 18 probably accumulated on a restricted shelf, inferring from the presence of anhydrite, anhydritic dolomite, and gray shale. In southern Wythe County, Virginia, about $70 \mathrm{mi}$ east of drill hole 18 (fig. 1), the Shady Dolomite thickens from 1,900 to 3,900 $\mathrm{ft}$ and forms a high-relief shelf-margin with algal reefs and adjoining fore-reef breccias (Barnaby and Read, 1990). The Lower to Middle Cambrian boundary (based on trilobite zones recognized by Willoughby, 1977) is placed by Barnaby and Read (1990) in the middle of the upper Shady Dolomite.

The Shady Dolomite is overlain by a unit of shale, argillaceous sandstone, and limestone that is named the Rome Formation (fig. 2). The contact between the Shady Dolomite and the Rome Formation is possibly an unconformity (Ryder, Crangle, and others, 2008). In some publications, an Early Cambrian age is commonly cited for the Rome Formation on the basis of very sparse fossil evidence (Palmer, 1971; Kulander and Dean, 1986; Evans and Troensegaard, 1991). In this report, however, a Middle Cambrian age is assigned to the Rome Formation along cross section $I-I^{\prime}$ based on (1) probable Middle Cambrian fossils in the Rome Formation in the Rome trough of western West Virginia (Donaldson and others, 1988), (2) Middle Cambrian fossils in the Rome Formation in Russell County of southwestern Virginia (Butts, 1940), and (3) stratigraphic reconstructions of the Shady Dolomite and Rome Formation in Wythe County of southwestern Virginia (Willoughby, 1977; Read, 1989a,b; Barnaby and Read, 1990).

In the Rome trough between the Irvine-Paint Creek and Rockcastle River faults (drill holes 10 to 11) the Rome Formation consists of approximately 1,600 to $3,000 \mathrm{ft}$ of gray to grayish-brown shale, argillaceous sandstone, and limestone. Between the Irvine-Paint Creek fault zone (downthrown side) and drill hole 10 , the unit of argillaceous sandstone (very fine to finegrained with local medium- to coarse-grained sand and granules) is about $1,100 \mathrm{ft}$ thick. This argillaceous sandstone unit of the Rome Formation thins to about $600 \mathrm{ft}$ in drill hole 11 and probably pinches out into gray shale about 3 mi northwest of the Rockcastle River fault. Between drill holes 10 and 11, the uppermost unit of the Rome Formation is a 300- to 500-ftthick argillaceous to sandy limestone. In the adjoining Perry County uplift, Floyd County embayment (drill hole 12), and Pike County uplift (drill hole 13), the Rome Formation consists of 1,300 to 2,200 ft of predominantly gray shale with thin beds of limestone. A 350- to 500-ft-thick unit of argillaceous limestone at the top of the Rome Formation in drill holes 12 and 13 correlates with the 300 - to 500-ft-thick unit of argillaceous to sandy limestone between drill holes 10 and 11. Also in drill hole 13 , red shale occurs locally in the lower $200 \mathrm{ft}$ of the Rome Formation. Between the Pike County uplift and the autochthonous section of lower Paleozoic strata in the primary footwall ramp of the Pine Mountain thrust fault (penetrated by well 18), the Rome Formation maintains a relatively uniform thickness of about 1,200 to $1,300 \mathrm{ft}$ and consists of predominantly grayish-green to red shale, dolomite, and anhydritic dolomite. The 200-ft-thick dolomite at the top of the autochthonous Rome Formation in drill hole 18 correlates with the 350 - to 500 -ft-thick limestone that forms the uppermost unit of the Rome Formation between drill holes 10 and 13 .

In the allochthonous strata penetrated by drill hole 18 , the previously described duplex structure in the core of the unnamed ramp anticline (fig. 3), between depths of about 5,300 and 7,100 ft, consists of three horse blocks of the Rome Formation that are characterized by red and green shale, dolomite, siltstone, and local anhydritic dolomite (L.D. Harris, unpub. data, 1979). The lowermost of the three horse blocks also contains a unit of anhydritic dolomite and anhydrite that is recognized as the Shady Dolomite, which is capped by an unconformity. This unconformity is overlain by the Rome Formation. Also in drill hole 18, the uppermost horse block in the Rome Formation is overlain in thrust contact by an allochthonous 720 -ft-thick section of the upper Rome Formation. Moreover, the Dumps and Honaker imbricate thrust faults in drill hole 18 involve the Rome Formation between the depths of 1,950 and 2,700 ft, and they override and conceal the unnamed ramp anticline. In outcrops of the Dumps and Honaker thrust faults, the Rome Formation is characterized by greenish-gray and grayish-red shale, siltstone, and discontinuous beds of dolomite and limestone that are as much as $50 \mathrm{ft}$ thick (Evans and Troensegaard, 1991).

About 4 mi southeast of drill hole 18, the Rome Formation is brought to the surface by the Copper Creek thrust fault. At the base of the Copper Creek thrust fault in Russell County, Butts (1940) described a 1,200-ft-thick incomplete section of the Rome Formation that consists predominantly of red shale with subordinate amounts of green shale, dolomite, and limestone. The westward facies change from predominantly red shale (described by Butts, 1940) in the Copper Creek thrust sheet to predominantly greenishgray and grayish-red shale (described by Evans and Troensegaard, 1991) in the Dumps and Honaker thrust sheets, and is interpreted to occur on cross section $I-I^{\prime}$ in the subsurface between the Honaker and Copper Creek thrust faults.

Between the Lexington fault and the Irvine-Paint Creek fault in the northwestern part of the Rome trough (drill holes 8 and 9), the 500- to 1,100-ft thick argillaceous and calcareous sandstone immediately below the Conasauga Group is mapped as the Rome Formation, and is interpreted to be equivalent to the 600- to 1,100-ft-thick argillaceous and calcareous sandstone mapped as the middle part of the Rome Formation in the central part of the Rome trough. In the northwestern part of the Rome trough, the argillaceous sandstone of the Rome Formation rests on an unconformity above the Shady Dolomite. Likewise, the argillaceous sandstone of the Rome Formation is capped by an unconformity, above which lies a 100-ft-thick gray shale that probably correlates with the Rogersville Shale of the Conasauga Group. From a thickness of 1,200 ft in drill 
hole 9, the argillaceous sandstone of the Rome Formation thins progressively to the northwest across successive fault blocks in the Rome trough, to a thickness of less than $100 \mathrm{ft}$ in drill hole 7, and then terminates against the Lexington fault. Haynes (1991) conducted a detailed outcrop study of the Rome Formation (equivalent to the Waynesboro Formation) near the Blue Ridge structural front in Botetourt County, Virginia, about 145 mi northeast of drill hole 18 . He concluded that the Rome Formation at this locality consists primarily of carbonate (limestone and dolomite), and only 10 to 20 percent of the formation consists of grayish-red and green clay mudrock.

A number of interpretations have been proposed for the Rome Formation. In Wythe County of southwestern Virginia and in Mingo County of western West Virginia (about 30 mi northeast of drill hole 13), the Rome Formation is interpreted as a shallow-water, nearshore marine to peritidal deposit (Donaldson and others, 1988; Barnaby and Read, 1990). In Botetourt County of southwestern Virginia, however, the Rome Formation is interpreted as only a peritidal deposit (Haynes, 1991).

West of drill hole 7, the Middle Cambrian sandstone of the Rome Formation and (or) the sandstone of the Lower Cambrian Chilhowee Group are replaced by the Middle to Upper Cambrian Mount Simon Sandstone as the basal sandstone northwest of the Rome trough. Between the Lexington fault zone and the northwestern end of cross section $I-I^{\prime}$, the Mount Simon Sandstone thickens to the west from less than $50 \mathrm{ft}$ thick to about $825 \mathrm{ft}$. From southeast to northwest across the Cincinnati arch, the Mount Simon Sandstone rests on an unconformity on basement rocks of the Grenville province (drill hole 6), basement rocks of the Middle Run Formation (from drill holes 2 to 6), and basement rocks of the eastern granite-rhyolite province (drill hole 1). In several localities near the crest of the Cincinnati arch (between drill holes 4 and 5) the Mount Simon Formation may be absent. In addition, the Mount Simon Sandstone is younger than both the Chilhowee Group (basal sandstone) and the Rome Formation (fig. 2) and is probably equivalent to one of the thin sandstone units in the Maryville Limestone of the Conasauga Group in the Rome trough in drill holes 7 through 9. The Mount Simon Sandstone is interpreted as a transgressive deposit that accumulated in a nearshore marine setting (Goodmann, 1992).

The Rome Formation is overlain by a unit of predominantly limestone, gray shale, sandstone, and local dolomite that is mapped as the Middle and Upper Conasauga Group (Formation) and which ranges in thickness from about 1,500 ft beneath the Allegheny structural front (drill hole 18) to about 350 to $500 \mathrm{ft}$ on the east flank of the Cincinnati arch (drill hole 6). West of the Lexington Fault Zone, strata that are equivalent to the Conasauga Formation and Maynardville Limestone are mapped as the Eau Claire Formation. In the central part of the Rome trough (drill hole 10) the Conasauga Group is 3,200 $\mathrm{ft}$ thick and rests on an unconformity above the Rome Formation. In the northern part of the trough (drill holes 7 through 9), however, the Conasauga Group ranges from about 900 to $1,100 \mathrm{ft}$ thick and rests on an unconformity above the Rome Formation (pre-Conasauga unconformity of Hickman and others, 2004). In drill holes 11 through 18 , the Conasauga Group is subdivided (in ascending order) into the Pumpkin Valley Shale, Rutledge Limestone, Rogersville Shale, Maryville Limestone, Nolichucky Shale, and Maynardville Limestone (fig. 2) In drill hole 10, the Pumpkin Valley Shale and Rutledge Limestone are replaced by an unnamed unit of sandstone and shale. The Middle and Late Cambrian ages of the Conasauga Group are based on trilobite fauna in outcrops of the Valley and Ridge province of southwestern Virginia (Butts, 1940; Derby, 1965).

In the Conasauga Group, the unnamed unit of sandstone and shale (Pumpkin Valley Shale and Rutledge Limestone equivalent) terminates against the Irvine-Paint Creek fault, but the overlying Rogersville, Maryville, Nolichucky, and Maynardville units extend to the northwest beyond the Irvine-Paint Creek fault.
The 100-ft-thick gray shale that is correlated with the Rogersville Shale rests on an unconformity above sandstone of the Rome Formation and extends across most of the northern part of the Rome trough before pinching out within $5 \mathrm{mi}$ southeast of drill hole 7 . The Marysville Limestone in drill hole 7 rests on an unconformity above the Rome Formation and terminates against the Kentucky River fault. Furthermore, the Maryville Limestone in this part of the Rome trough ranges from predominantly limestone to predominantly dolomite and contains several 5 - to 10 -ft-thick laterally continuous sandstone beds. As previously mentioned, one or more of these sandstone beds in the Marysville Limestone may correlate with the Mount Simon Sandstone. In contrast with the Rogersville Shale and Maryville Limestone, the Nolichucky Shale oversteps the northern margin of the Rome trough (Kentucky River fault), and in drill holes 1 through 6 the Nolichucky Shale is replaced by gray shale, limestone, and local red shale of the Conasauga Formation and the equivalent Eau Claire Formation. The Maynardville Limestone, which overlies the Nolichucky Shale, extends as far west as the Kentucky River fault before merging with the upper part of the Conasauga Formation. On the west side of the Cincinnati arch, a limestone unit that is equivalent to the Maynardville Limestone is present as the uppermost unit in the Eau Claire Formation in drill hole 1.

This limestone unit pinches out to the east against the western flank of the Cincinnati arch.

In the allochthonous rocks of the Valley and Ridge province on the southeastern part of cross section $I-I^{\prime}$, the Rutledge, Rogersville, and Maryville units of the

Conasauga Group are replaced by the Honaker Formation, which consists of a lower limestone unit, a middle dolomite unit, and an upper limestone unit (fig. 2). The lower limestone unit of the Honaker Formation is equivalent to the Rutledge Limestone (Butts, 1940). The middle dolomite unit is equivalent to the Rogersville Shale and Maryville Limestone (Read, 1989a,b). The upper limestone unit in the Honaker Formation (recognized by Cooper, 1945; Evans and Troensegaard, 
1991) probably correlates with the upper part of the Maryville Limestone. As suggested by Rodgers (1953), the Pumpkin Valley Shale of the Conasauga Group probably correlates with the lowermost Honaker Formation in the southwestern Virginia part of the Valley and Ridge province. In the autochthonous section beneath the Pine Mountain thrust fault, the Nolichucky Shale and Maynardville Limestone of the Conasauga Group continue to the southeast into the Valley and Ridge province as distinct units above the Honaker Formation (Markello and Read, 1982; Read, 1989a,b). In the Copper Creek thrust sheet, the Honaker Formation is between 1,120 and 1,375 ft thick and the Nolichucky Shale is between 385 and $459 \mathrm{ft}$ thick (Butts, 1940; Cooper, 1945). Along the Blue Ridge front in Washington County of southwestern Virginia (fig. 1), the Honaker Formation, Nolichucky Shale, and Maynardville Limestone are replaced by the Middle Cambrian Elbrook Formation and possibly the lower part of the Upper Cambrian Conococheague Group (Le Van and Rader, 1983; Koerschner and Read, 1989; Virginia Division of Mineral Resources, 1993).

The Conasauga Group in the Rome trough in Mingo County of western West Virginia (Donaldson and others, 1988) and in the Valley and Ridge of southwestern Virginia (Read, 1989a,b) is interpreted as tidal-flat to shallow-water marine deposits. Moreover, the sandstone unit in the pre-Rogersville Shale part of the Conasauga Group (drill hole 10) and the basal sandstone in the Maryville Limestone (drill hole 11) were probably derived from a cratonic source to the north and northwest. The abrupt changes in thickness of the Conasauga Group and the Rome Formation across basement fault blocks in the Rome trough and adjoining Perry County uplift, Floyd County embayment, and Pike County uplift suggest that these strata accumulated during the formation of the trough.

The Conasauga Group (Formation) and the equivalent Eau Claire Formation on the western flank of the Cincinnati arch and adjoining Illinois basin are overlain by a unit of dolomite and sandstone that is mapped as the Upper Cambrian and Lower Ordovician Knox Group (fig. 2). The Knox Group has a relatively uniform thickness that ranges from a maximum of about $2,100 \mathrm{ft}$ (drill hole 11) to 2,250 ft (drill hole 10) in the central part of the Rome trough to a minimum of about 1,700 to $1,900 \mathrm{ft}$ (drill holes 7, 8, and 9) near the western margin of the Rome trough. The Knox Group thins slightly to $1,800 \mathrm{ft}$ (drill hole 6 and probably drill hole 5) along the eastern flank of the Cincinnati arch and then thickens gradually to about 2,600 ft on the eastern flank of the Illinois basin (drill hole 1). In the Floyd County embayment (drill hole 12), the Pike County uplift (drill hole 13), and the autochthonous sequence beneath the unnamed ramp anticline (drill hole 18), the Knox Group ranges in thickness from about 1,600 to $1,750 \mathrm{ft}$. In the Valley and Ridge province, the thickness of the Knox Group increases to about 2,350 ft in the Honaker thrust sheet in central Russell County (Evans and Troensegaard, 1991) and to between 2,100 and 2,300 ft in eastern Russell County (Butts, 1940; Cooper, 1945). Near the Blue Ridge front in Washington County of southwestern Virginia (fig. 1), the Copper Ridge Dolomite of the Knox Group is replaced by the Upper Cambrian Conococheague Formation (Bartlett and Webb, 1971; Le Van and Rader, 1983; Virginia Division of Mineral Resources, 1993), which is overlain by the Chepultepec Dolomite, Kingsport Formation, and Mascot Dolomite (Bartlett and Webb, 1971) or Beekmantown Group (Virginia Division of Mineral Resources, 1993).

In drill hole 10, the Knox Group consists of the following formations (in ascending order): (1) the Copper Ridge Dolomite, which is a 1,400-ft-thick dolomite with local chert in the upper part; (2) the Rose Run Sandstone, which is a 250 -ft-thick unit of interbedded cherty dolomite and sandstone (quartzarenite) as much as $10 \mathrm{ft}$ thick; and (3) the Beekmantown Dolomite, which is a 600-ft-thick chert-bearing, sandy dolomite (fig. 2). These three formations of the Knox Group are present over much of cross section $I-I^{\prime}$, but in Virginia, as previously discussed, the Knox Group consists of four formations (fig. 2). These four formations of the Knox Group in Virginia are as follows (in ascending order): (1) the Copper Ridge Dolomite, which correlates with the Copper Ridge Dolomite in Kentucky; (2) the Chepultepec Dolomite, which correlates with the Rose Run Sandstone in Kentucky; (3) the Kingsport Formation, which correlates with the lower part of the Beekmantown Dolomite in Kentucky; and (4) the Mascot Dolomite, which correlates with the upper part of the Beekmantown Dolomite in Kentucky (Evans and Troensegaard, 1991). In the Honaker thrust sheet, Evans and Troensegaard (1991) recognized the Copper Ridge Dolomite and the Chepultepec Dolomite as a single unit, and they also recognized the Kingsport Formation and Mascot Dolomite as a single unit. In eastern Russell County, Virginia, Cooper (1945) treated units in the "Knox" dolomite in the same manner, recognizing several sandstone units in the upper part of the lower "Knox" dolomite (Copper Ridge Dolomite of Butts, 1940), but designating them as informal sandy members of the Knox. In addition, the Kingsport- and Mascot-equivalent strata in eastern Russell County were designated by Cooper (1945) as informal units such as the lower cherty member of the "Knox" dolomite.

The Late Cambrian and Early Ordovician age of the Knox Group is based primarily on conodont assemblages (A.G. Harris, unpub. data, 1979; Repetski, 1985; Ryder and others, 1997; Ryder, Crangle, and others, 2008) and on regional correlations (Le Van and Rader, 1983). However, the Chepultepec Dolomite in this report is assigned to the uppermost Cambrian (fig. 2), which differs from previous investigations that place the Chepultepec Dolomite in the lowermost Lower Ordovician (McGuire and Howell, 1963; Le Van and Rader, 1983; Bova and Read, 1987; Evans and Troensegaard, 1991). A Late Cambrian age assigned in this study to the sandstone-bearing Chepultepec Dolomite and to the equivalent Rose Run Sandstone (fig. 2) is based on the tentative Late Cambrian age assigned by Freeman (1953) to the Rose Run Sandstone in 
Kentucky. Moreover, the Rose Run Sandstone is probably correlative with the upper sandy member of the Gatesburg Formation in central Pennsylvania, which also is considered to be Cambrian in age (Wilson, 1952).

In drill holes 8 through 11, a 50-ft-thick silty dolomite unit in the middle part of the Copper Ridge Dolomite is tentatively correlated with the B zone of Calver (1964) in Ohio. As described by Janssens (1973), the B zone is a glauconitic siltstone and very fine grained sandstone that forms a persistent marker bed over much of central Ohio. The B zone also extends into parts of northern West Virginia (Ryder, Swezey, and others, 2008).

The Knox Group and the overlying Upper Ordovician carbonate strata (High Bridge Group and Lexington Limestone) are interpreted as deposits of a post-rift passive margin sequence. Furthermore, the Copper Ridge and Beekmantown Dolomites are interpreted as restricted shallow-marine deposits that accumulated on a passive continental margin or carbonate ramp (Harris 1973; Read, 1989a,b). The sandstone (quartzarenite) beds in the Rose Run Sandstone and equivalent Chepultepec Dolomite are interpreted as shallow-marine to peritidal deposits that accumulated on a carbonate ramp (Bova and Read, 1987; Riley and others, 1993). These sandstone beds probably were derived from the craton (Riley and others, 1993).

The Knox Group is capped by an unconformity, which is called the Middle Ordovician (Knox) unconformity (fig. 2) or Owl Creek unconformity (Sloss, 1963; Wheeler, 1963; Swezey, 2002, 2009). Judging from studies by Harris and Repetski (1982), Mussman and others (1988), Hickman and others (2004), and Noger and Drahovzal (2005), the Middle Ordovician (Knox) unconformity is present along all of cross section $I-I^{\prime}$. Unlike the Knox unconformity in central Ohio, where there is deep erosion into the underlying Knox and progressive truncation of older units toward the west (Ryder, Swezey, and others, 2008), the Knox unconformity in Kentucky and southwestern
Virginia is marked by far less erosion that is limited to the uppermost part of the Knox Group. The Middle Ordovician continental-scale erosion represented by the Knox unconformity is thought to have occurred during a drop in eustatic sea level and (or) tectonic uplift that preceded the Taconic orogeny (Read, 1989a,b).

The Knox unconformity is overlain by a 50 - to 300 -ft-thick unit of sandstone, argillaceous to calcareous dolomite, and dolomitic limestone across all of cross section $I-I^{\prime}$ (fig. 2). In Kentucky, the sandstone at the base of this unit is called the St. Peter Sandstone and the overlying dolomite is called the Wells Creek Dolomite (Freeman, 1953; McGuire and Howell, 1963 Humphreys and Watson, 1996; Hickman and others, 2004; Noger and Drahovzal, 2005). In Virginia, equivalent sandstone, dolomite, and dolomitic limestone units are the Blackford Formation and the overlying Elway, Five Oaks, and Lincolnshire Limestones. A Middle Ordovician age is assigned to the St. Peter Sandstone, Wells Creek Dolomite, Blackford Formation, and Elway-Five Oaks-Lincolnshire Limestones based on conodont assemblages (Bergstrom and Carnes, 1985; Ryder and others, 1997; Ryder, Crangle, and others, 2008) and regional correlations (Le Van and Rader, 1983)

On cross section $I-I^{\prime}$, the term Wells Creek dolomite is used informally because the term is common in the geologic literature. The Wells Creek Dolomite was first named by Lusk (1927) after a locality in western Tennessee. Wilson and Stearns (1968), however, discontinued the term in Tennessee when their geologic mapping failed to identify the Wells Creek Dolomite at the type locality. The name "Wells Creek Dolomite" was probably introduced in Kentucky by McGuire and Howell (1963) and used by Patchen and others (1985), Ryder and others (1997), Noger and Drahovzal (2005), and Hickman and others (2004, 2006).

The St. Peter Sandstone and overlying Wells Creek dolomite accumulated in a variety of depositional environments. The sandstone (quartzarenite) of the St. Peter Sandstone was probably derived from recycled Rose Run Sandstone and other sandstone units in the exposed Knox Group (Price, 1981). The St. Peter Sandstone is interpreted as shoreline deposits that filled topographic lows on the downthrown sides of rejuvenated basement faults (Price, 1981; Humphreys and Watson, 1996). The dolomite interval of the St. Pete Sandstone-Wells Creek dolomite and the equivalent Blackford-Elway-Five Oaks-Lincolnshire interval are interpreted as net transgressive deposits of tidal-flat origin that formed as marine conditions were reestablished across the exposed continental shelf (Read, 1980).

The Wells Creek dolomite and equivalent stratigraphic units are overlain by a widespread, westwardthinning wedge of Upper Ordovician limestone between the autochthonous section beneath the primary footwall ramp of the Pine Mountain thrust fault (drill hole 18) and the eastern flank of the Illinois basin (drill hole 1). The Late Ordovician age of the High Bridge Group in Kentucky, the High Bridge-equivalent limestone units in Virginia (shown on fig. 2), the Lexington Group in Kentucky, and the equivalent Trenton Limestone in Virginia is based on conodont assemblages (A.G. Harris, unpub. data, 1979; Sweet 1979, 1984; Bergstrom and Carnes, 1985; Richardson and Bergstrom, 2003; Ryder and others, 1997; Ryder, Crangle, and others, 2008) and on regional correlations (Le Van and Rader, 1983; Ettensohn, 1991; Pope and Read, 1997). Locally, the lower part of the Upper Ordovician limestone interfingers with the underlying Wells Creek dolomite. This wedge-shaped limestone interval is about $1,950 \mathrm{ft}$ thick in drill hole 18 , about $1,250 \mathrm{ft}$ thick in the central part of the Rome trough (drill hole 11), about $800 \mathrm{ft}$ thick in the northern part of the Rome trough, and about $650 \mathrm{ft}$ thick on the eastern margin of the Illinois basin (drill hole 1). Above the Wells Creek dolomite, the Upper Ordovician limestone is divided into the High Bridge Group and the overlying Lexington Limestone, following nomenclature used in the outcrop belt of the Cincinnati arch (Cressman, 1964, 1973; Black, 1968; Pope and Read, 1997), in the subsurface between the Cincinnati arch and the Illinois 
basin (Noger and Drahovzal, 2005), and in the subsurface between the Cincinnati arch and the Virginia State line (Pope and Read, 1997; Hickman and others, 2006; Riley and others, 2006). The following three formations of the High Bridge Group are recognized on cross section $I-I^{\prime}$ (in ascending order): (1) the Camp Nelson Limestone (an unnamed lower member that is equivalent to the Ordovician Joachim Dolomite elsewhere in the Illinois basin, the Pecatonica Member, and an unnamed upper member), (2) the Oregon Formation (combined in this report with the upper member of the Camp Nelson Limestone), and (3) the Tyrone Limestone. The Lexington Limestone is undivided on cross section $I-I^{\prime}$ except for an informal upper tongue located near drill hole 3 . This tongue of the uppermost Lexington Limestone probably represents the western margin of the Tanglewood Limestone Member of the Lexington Limestone of Cressman (1973) and the Tanglewood buildup of Ettensohn (1992b). A similar interval (about $80 \mathrm{ft}$ thick) in the uppermost Lexington Limestone is recognized in drill holes 8 through 10 .

In Virginia, the High Bridge Group is equivalent (in ascending order) to the Rockdell Limestone, Benbolt Formation, Wardell Formation, Bowen Formation, Witten Limestone, and Eggleston Limestone, whereas the Lexington Limestone is equivalent to the Trenton Limestone. The names of the Rockdell through Eggleston limestone units on cross section $I-I^{\prime}$ are based on units recognized in drill hole 18 by L.D. Harris (unpub. data, 1979) and on units recognized by Cooper (1945), Read (1980), and Le Van and Rader (1983) in outcrops in the Valley and Ridge province in southwestern Virginia. Likewise, the Trenton Limestone on cross section $I-I^{\prime}$ follows usage by L.D. Harris (unpub. data, 1979) in drill hole 18 and by Le Van and Rader (1983) in outcrops in the Valley and Ridge province. The Rockdell through Eggleston units and the Trenton Limestone are approximately equivalent to the Black River Group and Trenton Group, respectively, as used in northeastern West Virginia by Perry (1972).
The Rockdell through Eggleston units display some thickness and lithologic variability from the Honaker thrust sheet to the Cooper Creek thrust sheet. In the Honaker thrust sheet in central Russell County of Virginia (part of the Valley and Ridge province), the Rockdell through Eggleston unit varies in thickness from about 1,280 to 1,525 ft (Butts, 1940; Cooper, 1945; Evans and Troensegaard, 1991), and includes red shale beds in the Bowen Formation and calcareous reddish-gray shale (Moccasin Formation of Butts, 1940) that occur between the Witten and Eggleston Limestones. The overlying 200 to 230 -ft-thick Trenton Limestone, included on the cross section with the Middle and Upper Ordovician (undivided) unit, is very argillaceous and forms the lower part of the Martinsburg Formation (Cooper, 1945; Kreisa and Springer, 1987; Haynes, 1992). In contrast, in the Copper Creek thrust sheet in southwestern Russell County of Virginia, the Rockdell through Eggleston interval (including the Moccasin Formation) varies in thickness from about 1,100 to $1,300 \mathrm{ft}$ (Cooper, 1945) and is overlain by the Martinsburg Formation. In both the Honaker and Copper Creek thrust sheets in cross section $I-I^{\prime}$, the stratigraphic units above the Knox Group and below the Reedsville Shale (including the Moccasin Formation) are recognized as being Middle and Upper Ordovician age.

The Martinsburg Formation consists of a lower unit of 350- to 500-ft-thick gray shale, a middle unit of 150- to 500-ft-thick argillaceous fossiliferous limestone, and an upper unit of 400- to 650-ft-thick gray shale (Butts, 1940; Kreisa and Springer, 1987). The lower gray shale and middle argillaceous fossiliferous limestone units of the Martinsburg Formation of Kreisa and Springer (1987) constitute the Trenton Limestone (as previously noted in the Honaker thrust sheet), whereas the upper gray shale of the Martinsburg Formation constitutes the Reedsville Shale (as used in Le Van and Rader, 1983; Haynes, 1992; and this study).

The High Bridge Group and equivalent strata in Virginia consist mainly of carbonate mudstone and wackestone with mudcracks, burrows, and argillaceous laminae that are interpreted as tidal-flat and subtidal carbonate ramp deposits (Cressman and Noger, 1976; Read, 1980; Ettensohn, 1991). In comparison, the Lexington and Trenton Limestones consist mainly of fossiliferous argillaceous limestone (wackestone and packstone) that are interpreted as shallow-water (subtidal) net transgressive deposits that accumulated on an open-marine carbonate ramp (Cressman, 1973;

Ettensohn, 1991, 1992a; Haynes, 1992; Pope and Read, 1997; Riley and others, 2006). Overall, the LexingtonTrenton deposits are interpreted as representing a gradual deepening of water across the carbonate ramp (platform) as net transgression progressed. The Tanglewood Limestone Member of the Lexington Limestone at the crest of the Cincinnati arch is a carbonate grainstone that is interpreted as having accumulated during a brief period of regression (Ettensohn, 1992b).

As shown on cross section $I-I^{\prime}$ and in figure 2 , the following five widespread K-bentonite beds are identified (in ascending order) in the Ordovician strata: (1) the Hockett Bentonite Bed, (2) the Deicke Bentonite Bed, (3) the Millbrig Bentonite Bed, (4) the "Elkport" Bentonite Bed, and (5) the Dickeyville Bentonite Bed; all of which are recognized and described by Kolata and others (1996). The Hockett, Deicke, and Millbrig Bentonite Beds are located in the Tyrone Limestone of the High Bridge Group. Furthermore, the Hockett Bentonite Bed is used in this study to define the approximate base of the Tyrone Limestone, whereas the Millbrig Bentonite Bed is used in this study to define the approximate top of the Tyrone Limestone (Kolata and others, 1996). The Hockett Bentonite Bed is also used in this study to define the approximate top of both the Oregon Formation and the upper member of the Camp Nelson Limestone, undivided. The Deicke Bentonite Bed is located in the upper part of the Tyrone Limestone about 20 to $30 \mathrm{ft}$ below the Millbrig Bentonite Bed. The "Elkport" and Dickeyville Bentonite Beds are located in the lower part of the Lexington 
Limestone. The Hockett, "Elkport," and Dickeyville Bentonite Beds are not present in drill hole 2 and 3, but the Hockett is present in drill hole 1. In the western belt of the Valley and Ridge province of Virginia (drill holes 15 through 18), the Hockett Bentonite Bed is located in the upper part of the Witten Limestone (or Hardy Creek Limestone, according to Kolata and others, 1996), whereas the Deicke and Millbrig Bentonite Beds are located in the upper part and top, respectively, of the Eggleston Limestone (Haynes, 1992; Kolata and others, 1996). In western Virginia, the "Elkport" and Dickeyville Bentonite Beds are located in the lower part of the Trenton Limestone (Kolata and others, 1996). In the central belt of the Valley and Ridge province of Virginia, the Deicke and Millbrig Bentonite Beds are located primarily in the middle part of the Eggleston Limestone (Haynes, 1992). The K-bentonite beds identified on cross section $I-I^{\prime}$ are thought to be derived from extensive volcanic ash falls that occurred during the Late Ordovician phase of the Taconic orogeny (Huff and Kolata, 1990; Huff and others, 1992).

\section{Upper Ordovician to Lower Silurian Siliciclastic Strata}

The Upper Ordovician limestone on cross section $I-I^{\prime}$ is overlain by a westward-thinning wedge of Upper Ordovician to lower Silurian siliciclastic strata characterized by gray shale, limestone, red shale, and sandstone (fig. 2). These Upper Ordovician to lower Silurian siliciclastic strata rest conformably on Upper Ordovician limestone, and locally, the limestone and siliciclastic strata interfinger with one another. As shown on cross section $I-I^{\prime}$, the combined thickness of the Upper Ordovician and lower Silurian siliciclastic strata ranges from about 1,300 $\mathrm{ft}$ in the vicinity of the Allegheny structural front (drill hole 18) to between 500 and 850 $\mathrm{ft}$ above the central and northern parts of the Rome trough (drill holes 8 through 10). The section of Upper
Ordovician and lower Silurian siliciclastic strata are incomplete over much of the Cincinnati arch because of erosion, but the section re-emerges as a 400-ft-thick unit on the eastern margin of the Illinois basin (drill hole 1). The majority of the westward thinning of the Upper Ordovician and lower Silurian siliciclastic strata was caused by depositional thinning, but some was caused by pre-Upper Devonian erosion in the vicinity of the Cincinnati arch between drill holes 6 and 8 .

Nomenclature used for the Cincinnati arch outcrop belt (Black, 1967, 1968, 1974; McDowell, 1978, 1983; Weir and others, 1984; Pope and Read, 1997) and for the subsurface between the Cincinnati arch and the Virginia State line (Pope and Read, 1997; Hickman and others, 2006; Riley and others, 2006) indicates that the Kentucky part of the Upper Ordovician and lower Silurian siliciclastic strata consists of the following units (in ascending order): the Clays Ferry Formation, Garrard Siltstone, Calloway Creek Limestone, Ashlock Formation, Drakes Formation, Drowning Creek Formation of the Crab Orchard Group, Alger Shale of the Crab Orchard Group, and Keefer Sandstone (fig. 2). In the subsurface of eastern Kentucky (drill holes 12 through 14) the Drowning Creek Formation and Alger Shale are replaced in ascending order by the "Clinton" sandstone (equivalent to the Clinch Sandstone in Virginia) and the Rose Hill Formation. In the outcrop belt and subsurface between the Cincinnati arch and the Illinois basin (Noger and Drahovzal, 2005), the Upper Ordovician and lower Silurian siliciclastic strata consist of the following units (in ascending order): the Maquoketa Shale (Clays Ferry Formation equivalent and Kope Formation equivalent), Calloway Creek Limestone, Grant Lake Limestone (Ashlock Formation equivalent), Drakes Formation, Brassfield Formation, and Osgood Formation. The Late Ordovician age of the Maquoketa Shale, Clays Ferry Formation, Kope Formation, Garrard Siltstone, Calloway Creek Limestone, Grant Lake Limestone-Ashlock Formation, and Drakes Formation in Kentucky is based on conodont assemblages (Sweet,
1979, 1984) and on regional correlations (Le Van and Rader, 1983; Ettensohn, 1991; Pope and Read, 1997; Ryder, Crangle, and others, 2008)

The lower $100 \mathrm{ft}$ of the Maquoketa Shale in drill hole 1 consists of a dark-brown to gray shale that is equated with unit A of the Maquoketa Group in southeastern Indiana (Gray, 1972). This lower unit is similar to the "Utica shale" (informal term used by drillers) discussed by Gray (1972), Mitchell and Bergstrom (1991), and Kolata and others (2001). The "Utica shale" at this locality is interpreted as a possible deeper water deposit that accumulated in the southeastern flank of the Sebree trough (fig. 1), a northeast-trending oceanic passageway (through southern Indiana and southwestern Ohio) that connected the Reelfoot Rift to the Midcontinent region (Kolata and others, 2001).

In Virginia, the Upper Ordovician and lower Silurian siliciclastic strata nomenclature change as follows: (1) the Clays Ferry Formation, Garrard Siltstone, Calloway Creek Limestone, and Ashlock Formation, which consist of gray shale with abundant siltstone and carbonate, grade east into a unit of gray shale with siltstone and limestone interbeds that is named the Reedsville Shale (Ettensohn, 1991, 1992a; Pope and Read, 1997); (2) the Drakes Formation, which consists of limestone, gray shale, and local red shale, grades east into a unit of red shale and sandstone that is named the Juniata Formation (Ettensohn, 1991, 1992a; Pope and Read, 1997); and (3) the "Clinton" sandstone of Wilson and Sutton (1976) and the Drowning Creek Formation (Brassfield, Plum Creek Shale, and Oldham Members) of McDowell (1983) grade east into a sandstone that is named the Clinch Sandstone (Le Van and Rader, 1983; Dorsch and others, 1994). The lower Silurian Rose Hill Formation, including the Cacapon Sandstone Member is present in both Virginia and Kentucky (Smosna and Patchen, 1978). In Kentucky, the Rose Hill Formation extends west to within several miles of drill hole 11 where it is replaced by the Lulbegrud Shale Member, Waco Member, and Estill Shale Member of the Alger 
Shale (fig. 2). The Cacapon Sandstone Member of the Rose Hill Formation also extends west in Kentucky to about $5 \mathrm{mi}$ beyond drill hole 13. The lower Silurian Keefer Sandstone, which is a widespread unit situated at the top of Upper Ordovician and lower Silurian siliciclastic strata (Harris and others, 1994), extends from its western limit in Kentucky about $11 \mathrm{mi}$ northwest of drill hole 8 (where the sandstone is truncated by the overlying Upper Devonian unconformity) into southwestern Virginia (drill hole 19). In Kentucky, the Keefer Sandstone is also known as the Big Six sandstone, an informal driller's term (Meglen and Noger, 1996; Noger and others, 1996).

The lower Silurian Clinch Sandstone between drill holes 15 and 18 is about $150 \mathrm{ft}$ thick and consists of a lower unit of gray shale (Hagan Shale Member) and an upper unit of white sandstone (quartzarenite) The Clinch Sandstone is interpreted as shallow-marine shelf, shoreface, and fluvial to estuarine deposits (Dorsch and others, 1994).

In drill holes 12 through 18, the Clinch Sandstone (and the equivalent "Clinton" sandstone in Kentucky) is conformably overlain by the 300 - to 350 -ft-thick lower Silurian Rose Hill Formation. The Rose Hill Formation consists of gray shale, red shale, and red sandstone. About midway between drill holes 12 and 13, the lower part of the Rose Hill Formation is a unit of sandstone and hematitic red shale that is recognized as the Cacapon Sandstone Member (Smosna and Patchen, 1978). The Rose Hill Formation is interpreted as a low-energy shallow-marine shelf deposit (Smosna and Patchen, 1978).

The Rose Hill Formation is conformably overlain by the Keefer Sandstone, which is usually less than 50 $\mathrm{ft}$ thick. Following Harris and others (1994), the lower Silurian-upper Silurian boundary is placed at the top of the Keefer Sandstone (equivalent to the top of the Clinton Group). The Keefer Sandstone is interpreted as a wave-dominated marine coastal deposit (Smosna, 1983).

The Upper Ordovician and lower Silurian siliciclastic strata in the Copper Creek thrust sheet in the Valley and Ridge province have a combined thickness of approximately 1,300 to $1,500 \mathrm{ft}$. These strata in the Copper Creek thrust sheet near cross section $I-I^{\prime}$ consist of the following stratigraphic units (in ascending order): (1) the Upper Ordovician Reedsville Shale, which is a 470- to 650-ft-thick unit of gray shale and limestone in the upper part of the Martinsburg Formation as recognized by Butts (1940) and Kreisa and Springer (1987); (2) the Upper Ordovician Juniata Formation, which is a 200 - to 400 -ft-thick unit of red shale and sandstone (Butts, 1940; Diecchio, 1991); (3) the lower Silurian Clinch Sandstone, which is a $250-\mathrm{ft}-$ thick unit of white quartzarenite sandstone (Dorsch and Dreise, 1995); and (4) the lower Silurian Rose Hill Formation and Keefer Sandstone, which is a 220-ft-thick unit of shale and sandstone. In western Washington County of Virginia (fig. 1), the red shale and sandstone unit that contains the Rose Hill Formation and Keefer Sandstone was mapped by Bartlett and Webb (1971) as part of the Clinton Formation. These stratigraphic names are consistent with the nomenclature recognized in the Valley and Ridge of southwestern Virginia by Le Van and Rader (1983).

The Upper Ordovician to lower Silurian siliciclastic strata are interpreted as being derived from an easterly orogenic source and deposited as a wedge of clastic sediments in a rapidly subsiding foreland basin (Ettensohn, 1991, 1992a; Pope and Read, 1997). This foreland basin and its sedimentary deposits are associated with the continent-island arc collision of the Taconic orogeny (Colton, 1970; Milici and de Witt, 1988; Drake and others, 1989; Pavlides, 1989; Faill, 1997a). The Upper Ordovician Reedsville Shale in Virginia is interpreted as shallow-marine shelf and turbidite deposits that were derived from the Taconic orogenic belt (Diecchio, 1985, 1991; Ettensohn, 1991; Castle, 2001), whereas the equivalent Clays Ferry Formation, Garrard Siltstone, Calloway Creek Limestone, and Ashlock Formation in Kentucky are interpreted as mainly peritidal to subtidal deposits (Ettensohn, 1991; Pope and Read, 1997). The Juniata Formation and equivalent Drakes Formation are interpreted as delta plain, peritidal, and marginal marine redbed deposits that were derived from the Taconic orogenic belt (Diecchio, 1985, 1991; Ettensohn, 1991; Castle, 2001). The

Clinch Sandstone is interpreted as a paralic deposit that accumulated during early Silurian late-stage uplift of the Taconic orogenic belt (Dorsch and others, 1994). The westward increase in carbonates in the Upper Ordovician and lower Silurian siliciclastic strata in Kentucky is thought to reflect a substantial reduction in the westward dispersal of argillaceous marine sediments from the Martinsburg foreland basin.

The Juniata Formation and the equivalent Drakes Formation are capped by a widespread unconformity named the Cherokee unconformity (Dennison and Head, 1975; Ettensohn, 1991; Pope and Read, 1997; Swezey, 2002, 2009; Ryder, 2006). The OrdovicianSilurian boundary is customarily placed at this unconformity (Diecchio, 1985). On cross section $I-I^{\prime}$, the Cherokee unconformity is placed at the base of the Clinch Sandstone. Although Pope and Read (1997) recognized the Upper Ordovician lower Tuscarora Formation (Clinch Sandstone) and overlying Cherokee unconformity in southwestern Virginia (near cross section $I-I^{\prime}$ ), the authors of cross section $I-I^{\prime}$ found no compelling evidence in this study for an intraformational unconformity within the Clinch Sandstone. Dennison and Head (1975) suggested that the Cherokee unconformity resulted from a fall in eustatic sea level that was independent of the classic Taconic angular unconformity between Upper Ordovician and lower Silurian rocks in eastern Pennsylvania (Pavlides and others, 1968). Probably both a fall in eustatic sea level and Taconic orogenesis contributed to the Cherokee unconformity.

\section{Lower Silurian to Middle Devonian Carbonate and Evaporitic Strata}

Lower Silurian to Middle Devonian strata consist of a lithologically varied interval of limestone, cherty 
limestone, dolomite, anhydritic dolomite, anhydrite, and sandstone (fig. 2). The combined thickness of these stratigraphic units ranges from about $400 \mathrm{ft}$ in the vicinity of the Allegheny structural front and adjoining Valley and Ridge province (drill hole 18) to a zero edge about $11 \mathrm{mi}$ northwest of drill hole 8 on the eastern flank of the Cincinnati arch (Meglen and Noger, 1996). The westward thinning of upper Silurian to Middle Devonian carbonate and evaporitic strata to a zero edge is caused largely by pre-Upper Devonian erosion (Upper Devonian unconformity) that cuts progressively to the west and downsection across the strata between drill holes 7 and 12. Stratigraphic units in this interval are named as follows (in ascending order): the Lockport Dolomite and an equivalent limestone unit, Salina Formation and equivalent Wills Creek Formation and Tonoloway Limestone, Helderberg Group (Helderberg Limestone in eastern Kentucky) and equivalent lower Wildcat Valley Sandstone, Oriskany Sandstone and equivalent middle Wildcat Valley Sandstone, and Onondaga Limestone and equivalent Huntersville Chert and upper Wildcat Valley Sandstone (Freeman, 1951; Miller and others, 1977; Le Van and Rader, 1983; Currie and MacQuown, 1984; Diecchio and others, 1984; Shell and others, 1984). In eastern Kentucky, the informal driller's term "Corniferous" is commonly applied to all of these Silurian and Devonian carbonate and sandstone units and the underlying Keefer Sandstone or Big Six sandstone (Freeman, 1951; Currie and MacQuown, 1984; Noger and others, 1996). Following Denkler and Harris (1988a,b) and Harris and others (1994), the Silurian-Devonian boundary is placed within the lower part of the Helderberg Group (Helderberg Limestone).

The Lockport Dolomite in eastern Kentucky (drill holes 8 to 13) extends into Virginia (drill holes 15 and 16). Farther southeast, between drill holes 16 and 17, the Lockport Dolomite is replaced by an equivalent limestone unit. In Virginia, an unconformity caps this equivalent limestone unit and cuts progressively downsection in a southerly direction to drill hole 18 , where the equivalent limestone unit is completely truncated. The Salina Formation, which overlies the Lockport Dolomite near the Kentucky-Virginia border, is replaced in Virginia by the Tonoloway Limestone that extends south to the vicinity of drill hole 18 .

About $5 \mathrm{mi}$ south of drill hole 17, the lower $40 \mathrm{ft}$ of the Tonoloway Limestone are replaced by the Wills Creek Formation, which rests on the previously mentioned unconformity. In drill hole 18, where the Lockport-

Dolomite-equivalent limestone is absent, the Wills

Creek Formation rests on an unconformity above the Keefer Sandstone. The unconformity probably extends to the south into the Copper Creek thrust sheet in the Valley and Ridge province (drill hole 19), as suggested by missing section (Lockport Dolomite-equivalent strata, Tonoloway Limestone, and Wills Creek Formation) between the Keefer Sandstone and the Helderberg-equivalent part of the Wildcat Valley Sandstone (fig. 2). The Oriskany Sandstone, which overlies the Helderberg Limestone in eastern Kentucky between drill holes 12 and 14, changes nomenclature to the Wildcat Valley Sandstone in southwestern Virginia.

Upper Silurian to Middle Devonian carbonate and evaporitic strata have been removed by erosion over much of the Cincinnati arch, but they are present on the eastern margin of the Illinois basin (between drill holes 1 and 2) as a 220-ft-thick section with several intervening unconformities (fig. 2). In central Kentucky, the upper Silurian to Middle Devonian stratigraphic units are named as follows (in ascending order): (1) the Laurel Dolomite, (2) the Waldron Shale, (3) the Louisville Limestone, (4) the Brownsport Formation, (5) the Dixon Formation, and (6) the Sellersburg and Jeffersonville Limestones (Kepferle, 1974a,b; Noger and Drahovzal, 2005). The Laurel, Waldron, and Louisville strata correlate with the Lockport Dolomite on the eastern flank of the Cincinnati arch, whereas the Brownsport and Dixon Formations correlate with the Salina Formation on the eastern flank of the arch (McDowell, 1983). The Brownsport and Dixon Formations are capped by an unconformity, above which lies the
Sellersburg and Jeffersonville Limestones (undifferentiated), which correlate with the Onondaga Limestone on the eastern flank of the arch (Freeman, 1951).

The Keefer Sandstone is conformably overlain by the lower and upper Silurian Lockport Dolomite in eastern Kentucky and adjoining Virginia and by the Lockport equivalent limestone in southwestern Virginia. In addition, the Keefer Sandstone in southwestern Virginia is capped by an unconformity, above which lies the upper Silurian Wills Creek Formation (fig. 2). The Lockport Dolomite consists mainly of fine- to medium-crystalline dolomite with local skeletal grains and ooid buildups (Smosna and others, 1989; Noger and others, 1996). By comparison, the Lockport-Dolomite-equivalent limestone unit consists predominantly of micritic limestone.

The upper Silurian Salina Formation consists mainly of dolomite, anhydritic dolomite, and anhydrite. No halite has been reported from the Salina Formation in eastern Kentucky (Currie and MacQuown, 1984).

The upper Silurian Tonoloway Limestone is lithologically similar to the Salina Formation, except limestone is more common in the Tonoloway Formation. The upper Silurian Wills Creek Formation is differentiated from the Tonoloway Formation by having a greater abundance of limestone and black shale and local anhydrite.

The overall depositional setting of the Salina Formation, Tonoloway Limestone, and Wills Creek Formation is interpreted as a shallow basin with closed circulation where evaporites were surrounded by a carbonate shelf with normal sea water (Smosna and others, 1977).

Dolomite and evaporite beds in the Salina Formation, Tonoloway Limestone, and Wills Creek Formation signal an abrupt change on the carbonate shelf from normal circulation to greatly restricted circulation. The local limestone beds probably represent brief periods of accumulation on a carbonate shelf under more normal marine conditions. The abrupt change to restricted circulation was caused by a change to a very arid climate (Cecil and others, 2004). The Salina Formation 
is interpreted as greatly restricted shallow water and sabkha deposits (Tomastik, 1997).

On cross section $I-I^{\prime}$, the Salina Formation (and equivalent upper part of the Tonoloway Limestone) is overlain by the upper Silurian to Lower Devonian Helderberg Group (Helderberg Limestone) from drill hole 18 to within about $8 \mathrm{mi}$ southeast of drill hole 11 where the Helderberg Limestone is truncated by the Middle to Upper Devonian unconformity. The thickness of the Helderberg Group (Helderberg Limestone) ranges from about 20 to $60 \mathrm{ft}$. Between drill holes 15 and 18 in southwestern Virginia, the lowermost part of the Helderberg Group may be late Silurian in age (fig. 2). In the Copper Creek thrust sheet in the Valley and Ridge province (drill hole 19), the Helderberg Group is replaced by the lower part of the Wildcat Valley Sandstone (Miller and others, 1977), which rests on an unconformity, above which lies the Keefer Sandstone as correlated by Wilson and others (1981b). In eastern Kentucky, the Helderberg Limestone consists of calcareous mudstone with local medium to coarse grains of frosted quartz sand (Currie and MacQuown, 1984). The Helderberg strata are generally interpreted as normal marine deposits that accumulated in an intracratonic basin and on flanking carbonate shelves (Dorobek and Read, 1986; Smosna, 1988).

The Helderberg Group (Helderberg Limestone) is capped by an unconformity, above which lies the clean, quartzose Lower Devonian Oriskany Sandstone that extends across the southeastern part of cross section $I-I^{\prime}$ between drill holes 12 and 18 . Furthermore, the Oriskany Sandstone is capped by an unconformity that probably truncated the Oriskany Sandstone several miles southeast of drill hole 12 near the pinch-out edge shown by Diecchio and others (1984) and Opritza (1996). West of the Oriskany Sandstone pinch-out, the unconformities above and below the Oriskany merge together and are truncated by the Middle to Upper Devonian unconformity midway between drill holes 11 and 12. In the Copper Creek thrust sheet in the Valley and Ridge province (drill hole 19), the Oriskany
Sandstone may be represented by part of the Wildcat Valley Sandstone (Miller and others, 1977). The Oriskany-equivalent part of the Wildcat Valley Sandstone, if present, probably rests on an unconformity above the Helderberg-equivalent part of the Wildcat Valley Sandstone (fig. 2).

The Oriskany Sandstone has been interpreted as a shallow-marine deposit (Bruner, 1988; Harper and Patchen, 1996), although Cecil (2004a,b) has suggested a prior eolian provenance for the Oriskany Sandstone. The regional unconformities identified at the top and base of the Oriskany Sandstone (Meglen and Noger, 1996) probably were caused by falls in eustatic sea level (Dennison and Head, 1975). Many authors consider the unconformity at the base of the Oriskany Sandstone to be a regional unconformity named the Wallbridge unconformity (Sloss, 1963; Wheeler, 1963; Swezey, 2002, 2009). Dennison and Head (1975), however, considered the unconformity above the Oriskany Sandstone to represent the longer period of emergence and perhaps the greater decrease in water depth.

Between drill holes 12 and 17, the unconformity that caps the Oriskany Sandstone and equivalent Wildcat Valley Sandstone is overlain by the Middle Devonian Onondaga Limestone (Currie and MacQuown, 1984). The Onondaga Limestone consists of cherty carbonate mudstone with local quartz grains. Several miles south of drill hole 17, the Onondaga Limestone is replaced by the Huntersville Chert, which contains more abundant chert than the Onondaga Limestone. In outcrops in the Copper Creek thrust sheet at the southeastern end of cross section $I-I^{\prime}$ (Washington County, Virginia), the Huntersville Chert consists of fossiliferous chert, glauconitic sandstone, and greenish-gray siltstone (Bartlett and Webb, 1971). In drill hole 19 (also in the Copper Creek thrust sheet), the Huntersville Chert is either absent or is replaced by a thin sandstone in the uppermost part of the Wildcat Valley Sandstone that rests on an unconformity above the middle (Oriskany equivalent) part of the Wildcat Valley Sandstone (fig. 2).

\section{Middle Devonian to Middle Mississippian} Siliciclastic Strata

Middle Devonian to Middle Mississippian siliciclastic strata consist of black shale, gray shale, siltstone, and sandstone (fig. 2). The Middle Devonian to Middle Mississippian strata shown on cross section $I-I^{\prime}$ thin dramatically westward from as much as about $2,800 \mathrm{ft}$ in the vicinity of the Allegheny structural front in southwestern Virginia to about $1,850 \mathrm{ft}$ near the Kentucky-Virginia border (drill hole 14), and to about $700 \mathrm{ft}$ in eastern Kentucky (near drill hole 8). These strata are absent across the Cincinnati arch due to erosion, but they are present as a 40 -ft-thick unit bounded by unconformities on the eastern flank of the Illinois basin (drill hole 1). In the Valley and Ridge province of Virginia, part of the Middle Devonian to Middle Mississippian strata are present within frontal imbricates of the St. Paul (Hunter Valley) thrust fault. Also in the Valley and Ridge province, a complete 2,800-ft-thick section of Middle Devonian to Middle Mississippian strata are present in southeast-dipping beds of the Copper Creek thrust sheet (drill hole 19 and adjoining outcrops). The majority of the westward thinning of the Middle Devonian to Middle Mississippian siliciclastic unit is caused by regional depositional thinning (Roen, 1984; Ettensohn and others, 1988; de Witt and others, 1993).

In eastern Kentucky, the Middle Devonian to Middle Mississippian siliciclastic strata include the following units (in ascending order): (1) the Middle Devonian Marcellus Shale, (2) the Upper Devonian West Falls Formation (Rhinestreet Shale and Angola Shale Members), (3) the Upper Devonian Java Formation, (4) the Upper Devonian Ohio Shale (Huron Member, Three Lick Bed, Chagrin Shale, and Cleveland Member), (5) the Upper Devonian Bedford Shale, (6) the Upper Devonian Berea Sandstone, (7) the Lower Mississippian Sunbury Shale, and (8) the Lower and Middle Mississippian Borden Formation (fig. 2). 
On the eastern flank of the Cincinnati arch, about $6 \mathrm{mi}$ northwest of drill hole 8 , the Huron, Cleveland, and Sunbury black shale units merge into a single black shale unit, called the Chattanooga Shale (de Witt and others, 1993; Hamilton-Smith, 1993). The Chattanooga Shale is equivalent to the Upper Devonian-Lower Mississippian New Albany Shale (Kepferle, 1974a; Sable and Dever, 1990) on the eastern flank of the Illinois basin near drill hole 1 (fig. 2). The stratigraphy of the Middle Devonian-Lower Mississippian black shale units has been studied in great detail because of their role as hydrocarbon source rocks and reservoirs (Roen and Kepferle, 1993).

At least four additional stratigraphic names are applied to the Middle Devonian to Middle Mississippian strata in southwestern Virginia. First, the Marcellus Shale (in drill holes 14 through 18) is replaced by the Middle and Upper Devonian Millboro Shale in the Copper Creek thrust sheet (drill hole 19 and adjoining outcrops). In this area, the Millboro Shale consists of a lower part that is equivalent to the Marcellus Shale and an upper part, the top of which is possibly equivalent to the top of the Genesee Formation (Butts, 1940; Bartlett and Webb, 1971). The top of the Millboro Shale marks the top of the Middle Devonian on cross section $I-I^{\prime}$. Second, strata that are equivalent to the Chagrin Shale Huron Member (upper), Three Lick Bed, and Cleveland Member in eastern Kentucky (drill hole 14) extend into southwestern Virginia (drill hole 15 to 17 , and drill hole 19 and adjoining outcrops) where they are mapped on cross section $I-I^{\prime}$ as an Upper Devonian undivided unit of predominantly gray shale (fig. 2). Third, the Sunbury Shale in drill hole 17 and farther west correlates with the Big Stone Gap Shale in drill hole 19 (Bartlett and Webb, 1971). Fourth, the Lower and Middle Mississippian Borden Formation in Kentucky (Ettensohn and others, 1988; Lierman and others, 1992) is equated in southwestern Virginia with the Lower and Middle Mississippian Price Formation (Bartlett and Webb, 1971; Le Van and Rader, 1983; Kammer and Bjerstedt, 1986). On cross section $I-I^{\prime}$, the name Borden Formation (as used by Ettensohn, 2009) is preferred to the name Borden Group (as used by Harris and Sparks, 2000).

In Virginia, between the Allegheny structural front and the Kentucky-Virginia State line, the Price Formation is overlain by a 30 - to 50 -ft-thick unit of red to gray shale named the Maccrady Shale (Wilpolt and Marden, 1959; Le Van and Rader, 1983). In Kentucky, red to gray shale in the uppermost part of the Borden Formation correlates with the Maccrady Shale in Virginia and extends west to a pinch-out edge about 8 mi west of drill hole 12. In both southwestern Virginia and eastern Kentucky, the Maccrady Shale is capped by a regional unconformity (Matchen and Vargo, 1996; Vargo and Matchen, 1996). In the Greendale syncline at the southeastern end of cross section $I-I^{\prime}$, the Maccrady Shale thickens to about $400 \mathrm{ft}$ and consists of red shale, gray shale, anhydritic dolomite, and siltstone (Cooper, 1966; Le Van and Rader, 1983). About 40 mi northeast of drill hole 19 (and adjoining outcrops), also in the Greendale syncline, the Maccrady Shale is as much as $1,250 \mathrm{ft}$ thick and contains beds of anhydrite and salt that is probably halite (Cooper, 1966). Part of the overthickened section of the Maccrady Shale is attributed to flowage of the evaporites during thrust faulting (Withington, 1965). The Maccrady Shale in drill hole 19 and in adjoining outcrops of the Copper Creek thrust sheet is capped by an unconformity, above which lies the Greenbrier Group (Le Van and Rader, 1983; Al-Tawil and others, 2003).

The Upper Devonian to Middle Mississippian siliciclastic strata are interpreted as sediments derived from an easterly orogenic source and deposited in a rapidly subsiding foreland basin. This foreland basin and its sedimentary deposits (the Catskill delta complex of Woodrow and Sevon, 1985, and Boswell and others, 1996; and the Price-Rockwell delta complex of Boswell and others, 1996) are associated with the Acadian orogeny (Colton, 1970; Milici and de Witt, 1988; Osberg and others, 1989; Faill, 1997b). The 5,000- to 7,000-ftthick Middle Devonian to Middle Mississippian siliciclastic interval of sandstone, siltstone, and gray shale shown on cross sections $C-C^{\prime}$ (Ryder and others, 2012), $D-D^{\prime}$ (Ryder and others, 2009), and $E-E^{\prime}$ (Ryder, Swezey, and others, 2008) represent the more proximal part of the foreland basin deposits, whereas the 700to 2,800 -ft-thick interval of gray shale, black shale, siltstone, and minor sandstone shown on cross section $I-I^{\prime}$ represents the distal sediments that were deposited on the craton beyond the foreland basin (Ettensohn and others, 1988). The black shales are interpreted as anaerobic (anoxic) shallow-marine deposits (Roen, 1984; Ettensohn and others, 1988; Boswell, 1996). According to Ettensohn and others (1988), the subsiding foreland basin may have acted as a "giant sediment sink" that prevented coarser clastic sediment from reaching the distal areas in eastern Kentucky.

A regional unconformity is present among Middle to Upper Devonian strata across cross section $I-I^{\prime}$ (fig. 2). This unconformity is referred to as the Acadian unconformity (Wheeler, 1963; Swezey, 2002) and the Middle Devonian unconformity (de Witt and others,

1993). In drill holes 15 through 19 , this unconformity is present at the top of the Marcellus Shale and equivalent lower Millboro Shale (fig. 2). In drill holes 15 through 18 , however, the unconformity is probably disrupted by the upper detachment zone of the Pine Mountain thrust fault (fig. 3) that is located within the Marcellus Shale. West from drill hole 14 , successively younger Upper Devonian strata downlap on the Middle to Late Devonian unconformity. For example, at drill hole 14 the partially eroded Marcellus Shale is overlain by the Upper Devonian Rhinestreet Shale Member of the West Falls Formation. About 6 mi west of drill hole 12, the Upper Devonian Angola Shale Member of the West Falls Formation rests on an unconformity above the Middle Devonian Onondaga Limestone. Farther west in drill hole 11, the Upper Devonian Java Formation rests on an unconformity above the upper Silurian Salina Formation. In drill holes 9 and 10, the Upper Devonian Huron Member (lower) of the Ohio Shale rests on an unconformity above the Salina Formation. At the western outcrop limit of the Upper Devonian 
black shale on the eastern flank of the Cincinnati arch, the Chattanooga Shale rests on an unconformity above the lower Silurian Brassfield Member of the Drowning Creek Formation. The Middle to Late Devonian unconformity is also recognized at the western end of cross section $I-I^{\prime}$ where the New Albany Shale rests on an unconformity above the Middle Devonian Sellersburg and Jeffersonville Limestones (undifferentiated).

The Upper Devonian Bedford Shale and the overlying Upper Devonian Berea Sandstone consist of a 20- to 100-ft-thick interval of shale, siltstone, and sandstone (Pashin and Ettensohn, 1995). This interval extends from drill hole 14 to about $7 \mathrm{mi}$ northwest of drill hole 8, and pinches out in the upper part of the Chattanooga Shale. A quartz-pebble conglomerate at the southeastern end of cross section $I-I^{\prime}$ (drill hole 19 and adjoining outcrops) is probably equivalent to the Berea Sandstone (unnamed quartz-pebble conglomerate at the top of the Chemung Formation of Bartlett and Webb, 1971; Cloyd Conglomerate of Wilson and others, 1981b). Between drill hole 16 and its pinch-out edge near drill hole 8, the Cleveland Shale Member of the Ohio Shale is conformably overlain by the Bedford Shale and an equivalent unnamed unit of sandstone and shale.

The Bedford Shale is overlain by the Berea Sandstone. West of drill hole 13, the contact between these two units is conformable. In drill holes 13 to 16 the Bedford Shale and (or) the equivalent unnamed sandstone and shale unit are capped by an unconformity, above which lies the Berea Sandstone. In drill hole 17 and drill hole 19 (and adjoining outcrops), this unconformity caps Upper Devonian undivided strata, above which lies the Berea Sandstone. This unconformity at the base of the Berea Sandstone is sometimes referred to as the Kaskaskia I-Kaskaskia II boundary (Sloss, 1988; Swezey, 2002).

The Bedford Shale-Berea Sandstone sequence is interpreted by Pashin and Ettensohn (1995) as a lowstand wedge that represents a major seaward shift in the upper part of the Devonian to Mississippian siliciclastic strata. The suggested eustatic drop in sea level possibly was associated with Late Devonian glaciations (Brezinski and others, 2010). The Berea Sandstone probably occupied a westward-prograding, sand-rich marine shelf that was dominated by storm deposits (Pashin and Ettensohn, 1995). The finer-grained Bedford Shale is interpreted as slope deposits on the westward-prograding shelf.

The Berea Sandstone is overlain by the Lower Mississippian Sunbury Shale, which is the uppermost black shale of the Upper Devonian to Middle Mississippian siliciclastic strata. This black shale represents the final transgression of the cratonic seaway across the distal part of the foreland basin (Ettensohn and others, 1988).

On cross section $I-I^{\prime}$, the Sunbury Shale, Big Stone Gap Shale, and Chattanooga Shale are overlain conformably by the Lower to Middle Mississippian Borden Formation and Price Formation. The Borden Formation in eastern Kentucky (drill holes 8 to 14) and the equivalent Lower to Middle Mississippian Price Formation in southwestern Virginia (drill holes 15 to 17 , and 19 and adjoining outcrops) consist primarily of silty shale overlain by siltstone. These two formations range in thickness from $900 \mathrm{ft}$ in drill hole 19 (and adjoining outcrops) to about $550 \mathrm{ft}$ at their outcrop limit between drill holes 7 and 8. The Borden Formation is only 340 to $230 \mathrm{ft}$ thick in drill holes 11 and 12, respectively.

The Borden and Price Formations on cross section $I-I^{\prime}$ are interpreted as shallow-marine prodeltaic and delta-front deposits that formed on the distal part of the westward-prograding siliciclastic strata. The variations in thickness of the Borden Formation in drill holes 11 and 12 is probably the result of syndepositional movement of an underlying basement block in the Rome trough.

The Price Formation is overlain by the Maccrady Shale, which consists of evaporite beds and red beds.
Evaporite beds in the Maccrady Shale are mainly confined to the Greendale syncline. In drill hole 19 and in adjoining outcrops of the Copper Creek thrust sheet, the Maccrady Shale is capped by an unconformity.

The Maccrady Shale is interpreted as having accumulated in a semiarid to arid environment (AlTawil and others, 2003). The Greendale syncline in which the Maccrady Shale accumulated is interpreted as a syndepositional basin of restricted circulation (Cooper, 1966, 1968). Overthickening of the Maccrady Shale within the Greendale syncline is attributed to flowage of the evaporites during subsequent thrust faulting (Withington, 1965).

\section{Middle and Upper Mississippian Carbonate Strata}

Middle and Upper Mississippian carbonate strata consist of a westward thinning wedge composed of the following units (in ascending order): (1) limestone, mapped as the Greenbrier Limestone in Virginia and the Newman Limestone in Kentucky; (2) limestone and black shale, mapped as the lower Bluefield Formation in Virginia; and (3) gray shale and sandstone mapped as the upper Bluefield Formation in Virginia (fig. 2). The combined thickness of the Greenbrier Limestone (Newman Limestone) and the overlying Bluefield Formation and equivalent strata ranges from about $1,200 \mathrm{ft}$ near the Allegheny structural front in southwestern Virginia to about $100 \mathrm{ft}$ near its outcrop limit in eastern Kentucky between drill holes 7 and 8 . Along the outcrop belt of the Middle and Upper Mississippian carbonate strata in eastern Kentucky and adjoining subsurface in eastern Kentucky, Ettensohn and others (1984, 1992c) and Ettensohn, Johnson, and others (2002) proposed that the name Newman Limestone be changed to the Slade Formation. This suggested revision is followed in cross section $I-I^{\prime}$, but the Slade Formation usage is restricted to the outcrop belt along the eastern flank of 
the Cincinnati arch and to the nearby subsurface in drill holes 8 and 9 north of the Irvine-Paint Creek fault zone.

The Greenbrier Limestone consists mainly of very finely crystalline limestone (carbonate mudstone) and fossiliferous limestone (wackestone, packstone, and grainstone) that is commonly oolitic with minor amounts of siliciclastic claystone, gray to grayish-red shale, and argillaceous carbonate mudstone (Meissner, 1978; Evans and Troensegaard, 1991). The Greenbrier Limestone thickens significantly to about 3,500 ft in the Greendale syncline (fig. 1) in southwestern Virginia at the southeastern end of cross section $I-I^{\prime}$ (drill hole 19 and adjoining outcrops), where the strata are named the Greenbrier Group (Al-Tawil and others, 2003). On the basis of studies by Bartlett and Webb (1971) and Al-Tawil and others (2003) and of strata penetrated in drill hole 19, the Greenbrier Group is subdivided into the following units (listed in ascending order): (1) the Little Valley Limestone, which is about $900 \mathrm{ft}$ thick; (2) the Hillsdale Limestone, which is about $260 \mathrm{ft}$ thick; (3) the Saint Genevieve Limestone, which is about 1,300 ft thick; and (4) the Gasper Limestone, which is a minimum of $1,040 \mathrm{ft}$ thick. The Greenbrier Group consists primarily of fossiliferous limestone (carbonate mudstone, wackestone, packstone, and grainstone) that is commonly oolitic and locally cherty. In addition to the dominant limestone units, thick quartzose siltstone units are present in the lower $400 \mathrm{ft}$ of the Little Valley Limestone and the upper $650 \mathrm{ft}$ of the Saint Genevieve Limestone of the Greenbrier Group. The quartzose siltstone units in the lower part of the Little Valley Limestone are dolomitic and commonly are interbedded with dolomite, whereas the quartzose siltstone units in the upper part of the Saint Genevieve Limestone are calcareous and commonly are interbedded with gray shale. Calcareous quartzose siltstone beds are also common in the upper $500 \mathrm{ft}$ of the Little Valley Limestone, where the siltstone is interbedded with brown to dark-gray shale and dominant argillaceous limestone. Thin red shale units in the lower $200 \mathrm{ft}$ of the Gaspar
Limestone may be equivalent to the Taggard Shale of the Greenbrier Group as recognized in southeastern West Virginia and southwestern Virginia by Al-Tawil and others (2003) and Stamm (2004).

The Newman Limestone and Bluefield Formationequivalent strata in eastern Kentucky and the equivalent Slade Formation in central Kentucky are lithologically similar to the Greenbrier Limestone in Virginia (MacQuown and Pear, 1983) but are marked by several unconformities near the Cincinnati arch (Ettensohn, Johnson, and others, 2002). The lower part of the Bluefield Formation in Virginia and the equivalent upper part of the Newman Limestone in Kentucky are dominated by skeletal limestone (packstone and grainstone) and black shale, whereas the upper part of the Bluefield Formation in Virginia is dominated by gray shale and sandstone (Maynard and others, 2006). The thin dolomite and gray shale unit that is equivalent to the Bluefield Formation (between drill holes 8 and 9) is included with the Slade Formation. In eastern Kentucky and southwestern Virginia, the Bluefield Formation and equivalent strata are capped by an unconformity (fig. 2)

The Middle and Upper Mississippian carbonate

strata are interpreted as having accumulated in several depositional environments. The Greenbrier Group (Limestone) in Virginia and the equivalent parts of the Newman Limestone and Slade Formation in Kentucky are interpreted as predominantly shallow-water openmarine to tidal-flat deposits on an east-facing carbonate ramp (Carney and Smosna, 1989; Ettensohn and others, 1992c; Ettensohn, Greb, and others, 2002; Ettensohn, Johnson, and others, 2002; Al-Tawil and others, 2003). The thick Greenbrier Group in southwestern Virginia is interpreted as deeper water deposits of the ramp margin, and the calcareous quartzose siltstone units in the Greenbrier Group are interpreted as lowstand deposits (Al-Tawil and others, 2003). The lower part of the Bluefield Formation and the equivalent upper part of the Newman Limestone in Kentucky represents the waning stages of marine carbonate shelf deposition
(Maynard and others, 2006). In contrast, the upper part of the Bluefield Formation (gray shale and sandstone unit) in Virginia represents the initial encroachment of nearshore marine and upper coastal plain terrigenous sediment from tectonic uplands to the east (Englund, 1979; Englund and Thomas, 1990).

The westward thinning of the Middle and Upper Mississippian carbonate strata resulted from the following events: (1) depositional thinning against the Cincinnati arch, which was tectonically active at the time of sediment accumulation (Ettensohn, Greb, and others, 2002; Ettensohn, Johnson, and others, 2002); (2) truncation of the upper part (gray shale and sandstone) of the Bluefield Formation by the post-Bluefield Formation unconformity east of drill hole 11 (Miller and Eriksson, 2000); and (3) partial truncation of the top of the Slade Formation between drill holes 7 and 8 by the Lower Pennsylvanian unconformity (fig. 2).

The thick Greenbrier Group in Virginia is attributed to increased accommodation space in a subsiding Middle to lower Upper Mississippian foreland basin created by thrust loading of the continental margin (Al-Tawil and others, 2003).

\section{Upper Mississippian and Pennsylvanian Siliciclastic Strata}

The westward-thinning wedge of Middle and Upper Mississippian carbonate strata on cross section $I-I^{\prime}$ is succeeded by a westward-thinning wedge of Upper Mississippian and Pennsylvanian siliciclastic strata that is characterized by sandstone, conglomeratic sandstone, gray shale, red shale, dark-gray to black shale, coal, and limestone (fig. 2). The Upper Mississippian and Pennsylvanian siliciclastic wedge changes thickness across cross section $I-I^{\prime}$ from about $4,000 \mathrm{ft}$ in the vicinity of the Allegheny structural front to about $300 \mathrm{ft}$ on the eastern flank of the Cincinnati arch near drill hole 8 . 
In drill holes 15 through 17 (and adjacent outcrops) in southwestern Virginia (fig. 2), the Upper Mississippian strata consist of the Hinton and Bluestone Formations of the Pennington Group. The previously cited nomenclature applied to Upper Mississippian strata in the southwestern Virginia part of cross section $I-I^{\prime}$ is significantly different from the nomenclature applied to Upper Mississippian strata in the eastern and central Kentucky parts of cross section $I-I^{\prime}$. For example, the Hinton and Bluestone Formations of the Pennington Group in southwestern Virginia (Miller and Meissner, 1977; Meissner, 1978) are not recognized in eastern Kentucky, where strata equivalent to the Hinton and Bluestone Formations are designated as the Pennington Formation (Ettensohn, Greb, and others, 2002; S.F. Greb, written commun., 2010). In addition, the westernmost part of the Pennington Formation (located approximately between the Irvine-Paint Creek fault and its pinch-out edge near drill hole 8) was renamed the Paragon Formation by Ettensohn (2009) and Ettensohn and others (1984, 1992c).

In southwestern Virginia, the Bluefield Formation is capped by an unconformity, above which lies a 280- to 760-ft-thick unit of sandstone, red shale, and fossiliferous limestone that is mapped as the Upper Mississippian Hinton Formation (Miller and Eriksson, 2000; Maynard and others, 2006). The Hinton Formation is divided into the following four members (in ascending order): (1) the Stony Gap Sandstone Member, (2) the middle red member (red shale, siltstone, and sandstone), (3) the Little Stone Gap Member (fossiliferous limestone), and (4) the Tallery Sandstone Member (Wilpolt and Marden, 1959; Miller, 1974; Meissner,

1978; Englund and Thomas, 1990).

The Hinton Formation is capped by an unconformity, above which lies the Upper Mississippian Bluestone Formation (Englund and others, 1985; Miller and Eriksson, 2000), which in southwestern Virginia consists of a 600-ft-thick unit of black shale and red beds. In southwestern Virginia, the Bluestone Formation consists of the following units (in ascending order): (1) the
Pride Shale Member (black shale), (2) the red member (predominantly red shale), and (3) the Bramwell Member (calcareous shale and siltstone), which is probably absent in the vicinity of cross section $I-I^{\prime}$ (Miller, 1974; Englund and others, 1985). In eastern Kentucky, strata equivalent to the Pride Shale Member tapers westward to a zero edge between drill holes 11 and 12 .

In drill holes 15 through 17 (and adjacent outcrops) in southwestern Virginia, the Lower Pennsylvanian strata consists of the following units (in ascending order): the Pocahontas Formation, the Lee Formation, the Norton Formation, the Gladeville Sandstone, and the Wise Formation (Wilpolt and Marden, 1959; Miller and Meissner, 1977; Englund, 1979; Meissner, 1978; Le Van and Rader, 1983; Mitchell and others, 1984; Englund and Thomas, 1990; Greb and others, 2004, 2009). The combined Pennsylvanian stratigraphic units in southwestern Virginia (the Lee Formation, Norton Formation, Gladeville Sandstone, and Wise Formation) correlate with the Lower and Middle Pennsylvanian Breathitt Group in eastern Kentucky (Chesnut, 1992; Greb and others, 2004, 2009). The Pennsylvanian Pocahontas Formation in southwestern Virginia pinches out before it reaches eastern Kentucky (Miller, 1974; Englund, Windolph, and others, 1986; Chesnut, 1992; Greb and others, 2009).

As shown in figure 2, Upper Mississippian strata are separated from Pennsylvanian strata by the regional Lower Pennsylvanian unconformity (Wilpolt and Marden, 1959; Rice, 1985; Englund and Thomas, 1990; Ettensohn, 1994; Greb and others, 2004, 2009). This unconformity is referred to as the sub-Absaroka unconformity (Sloss, 1963, 1988; Wheeler, 1963; Swezey, 2002). To the west across southwestern Virginia and eastern Kentucky, this unconformity truncates the lowermost Pennsylvanian Pocahontas Formation and progressively older Upper Mississippian strata (Englund and Thomas, 1990; Ettensohn, 1994). Furthermore, Pennsylvanian strata that overlie the Lower Pennsylvanian unconformity are arranged in an onlap configuration where progressively younger rocks rest on the unconformity toward the Cincinnati arch (Englund and Thomas, 1990; Chesnut, 1992; Ettensohn, 1994; Greb and others, 2004, 2009).

In eastern Kentucky, the Lower Pennsylvanian unconformity is overlain by the Lower and Middle Pennsylvanian Breathitt Group, which consists of quartzose sandstone, quartzose conglomeratic sandstone, sandy gray shale, gray shale, and coal (fig. 2). This interval ranges in thickness from about 2,400 ft in front of the secondary footwall ramp of the Pine Mountain thrust fault (near drill hole 14) to about 1,500 $\mathrm{ft}$ above the Rockcastle River fault zone (between drill hole 11 and 12), and to about $300 \mathrm{ft}$ along the eastern flank of the Cincinnati arch in outcrops within 3 to 5 mi of drill hole 8 . Interbedded quartzose sandstone, quartzose conglomeratic sandstone, and coal-bearing gray shale in the Breathitt Group of central and eastern Kentucky are divided into the following formations (in ascending order): (1) the Warren Point Sandstone, (2) the Bottom Creek Formation, (3) the Sewanee Sandstone, (4) the Alvy Creek Formation, (5) the Bee Rock Sandstone, (6) the Grundy Formation, (7) the Pikeville Formation, (8) the Hyden Formation, (9) the Four Corners Formation, and (10) the Princess Formation (Chesnut, 1992; Greb and others, 2004, 2009). The Grundy Formation consists of an unnamed lower unit of coal beds and sandstone and an upper sandstone named the Corbin Sandstone Member. The more comprehensive sections of the Breathitt Group along cross section $I-I^{\prime}$ are present between drill holes 10 and 12 where the Four Corners and Princess Formations are preserved in a structural sag (Eastern Kentucky syncline of Chesnut, 1992) that approximately overlies the eastern limit of the Rome trough and the adjoining Floyd County embayment. Many of these strata within the Breathitt Group contain coal beds that range from 1 to $12 \mathrm{ft}$ thick, but these coal beds are not identified individually on cross section $I-I^{\prime}$.

In southwestern Virginia, the Lower Pennsylvanian unconformity is overlain by Pennsylvanian quartzose sandstone, quartzose conglomeratic sandstone, and 
coal-bearing sandy shale that are mapped as the following formations (in ascending order): (1) the Lee Formation, (2) the Norton Formation, and (3) the Gladeville Sandstone. The Lee Formation is divided into the following three members (in ascending order): (1) the Middlesboro Member, (2) the Hensley Member, and (3) the Bee Rock Sandstone Member (upper quartzarenite member of Mitchell, 1982). The Middlesboro Member contains a lower sandstone unit (lower quartzarenite of Mitchell, 1982; lower quartzarenite of the Middlesboro Member of Nolde, 1994) and an upper sandstone unit (middle quartzarenite of Mitchell, 1982; upper quartzarenite of the Middlesboro Member of Nolde, 1994). Correlations reported by Chesnut (1992) and made in this study indicate that the lower and upper sandstone units of the Middlesboro Member of the Lee Formation are equivalent to the Warren Point and Sewanee Sandstones, respectively, of the Breathitt Group, whereas the Bee Rock Sandstone Member of the Lee Formation is equivalent to the Bee Rock Sandstone of the Breathitt Group (fig. 2). The Bee Rock Sandstone Member of the Lee Formation thins to the east and changes across an arbitrary boundary between drill holes 16 and 17 to the McClure Sandstone Member of the Norton Formation (Miller, 1974; Meissner, 1978; Mitchell, 1982). An unnamed sandstone of the Norton Formation that is recognized on cross section $I-I^{\prime}$ is correlated with an unnamed sandstone of the Grundy Formation that is also recognized on cross section $I-I^{\prime}$ (fig. 2). The Gladeville Sandstone (fig. 2) is the youngest of the Pennsylvanian sandstone units in southwestern Virginia and is approximately equivalent to the Corbin Sandstone Member of the Grundy Formation (Greb and others, 2004).

The major beds of quartzose sandstone, quartzose conglomeratic sandstone, and shale in the Breathitt Group (in Kentucky) and the Lee Formation (in Virginia) extend west across large parts of cross section $I-I^{\prime}$ before they thin, onlap, and terminate against the Lower Pennsylvanian unconformity. For example, from the St. Paul (Hunter Valley) thrust fault to drill hole 15 in southwestern Virginia, the lower sandstone of the Middlesboro Member of the Lee Formation (equivalent to the Warren Point Sandstone of the Breathitt Group) rests on an unconformity above the Lower Pennsylvanian Pocahontas Formation. Northwest of the Pine Mountain thrust fault, the Lower Pennsylvanian unconformity truncates the Pocahontas Formation and places the Breathitt Group on top of the red member of the Bluestone Formation. In drill hole 14, strata in the Pennington Formation that are equivalent to the Pride Shale Member of the Bluestone Formation are capped by the Lower Pennsylvanian unconformity, above which lies the Warren Point Sandstone. Thus, strata in the Pennington Formation that are equivalent to the red member of the Upper Mississippian Bluestone Formation have been truncated by the Lower Pennsylvanian unconformity. Locally (such as between drill hole 14 and the Pine Mountain thrust fault), the Warren Point Sandstone overlies Pennsylvanian shale and silty shale of the Breathitt Group that are difficult to differentiate from underlying Mississippian shale. In such cases, the location of the Lower Pennsylvanian unconformity is difficult to recognize. Furthermore, between drill holes 11 and 12, the Bee Rock Sandstone of the Breathitt Group rests on an unconformity above the truncated western limit of strata in the Pennington Formation that are equivalent to the Upper Mississippian Hinton Formation. To the west (between drill holes 9 and 10), the Bee Rock Sandstone thins to a pinch-out edge and rests on an unconformity above the lower part of the Pennington Formation. Finally, between the IrvinePaint Creek fault and the western outcrop limit of the Breathitt Group, the Grundy Formation and its Corbin Sandstone Member rest on an unconformity above the Lower and Middle Mississippian Slade Formation.

The Upper Mississippian and Pennsylvanian siliciclastic strata are interpreted as predominantly nonmarine sediments (with minor amounts of restricted marine sediments) derived from an easterly source and deposited in a subsiding foreland basin (Englund and Thomas, 1990). This foreland basin and its sedimentary deposits are associated with the Alleghanian orogeny (Colton, 1970; Milici and de Witt, 1988; Hatcher and others, 1989). In contrast, Ettensohn, Greb, and others (2002) and Ettensohn (2009) consider the Upper Mississippian deposits to be associated with the final stages of the Acadian orogeny. Westward thinning of the Upper Mississippian strata resulted from depositional thinning and erosional truncation beneath the Lower Pennsylvanian unconformity. Furthermore, depositional thinning of Upper Mississippian strata (below the Lower Pennsylvanian unconformity) and Pennsylvanian strata (above the Lower Pennsylvanian unconformity) probably was controlled in part by syndepositional uplift of the Cincinnati arch.

The fossiliferous limestone of the Little Stone Gap Member of the Hinton Formation is interpreted as a shallow restricted-marine deposit (Wilpolt and Marden, 1959), whereas the black shale of the Pride Shale

Member of the Bluestone Formation is interpreted as a brackish-water lagoonal deposit (Englund and Thomas, 1990). The remaining strata of the Hinton and Bluestone Formations are interpreted as alluvial plain and marginal-marine deposits (Miller, 1974; Englund and others, 1985).

The quartzose sandstone and quartzose conglomeratic sandstone of the Pocahontas Formation, Breathitt Group, and Lee Formation are interpreted as being primarily fluvial (Rice and Schwietering, 1988; Greb and Chesnut, 1996; Greb and others, 2004, 2009). In contrast, Englund, Windolph, and others (1986) and Englund, Gillepsie, and others (1986) interpreted the sandstone and conglomeratic sandstone as barrier-bar and offshore-bar deposits. Coal-bearing sandstone and gray shale in the Pocahontas Formation, Breathitt Group, Lee Formation, Norton Formation, and Wise Formation are interpreted as alluvial plain, coastal plain, and peat swamp deposits (Englund and Thomas, 1990; Greb and others, 2004, 2009). Thin, commonly widespread beds of shale, with marine fauna, near the base of the Pikeville, Hyden, Four Corners, and Princess Formations of the Breathitt Group probably 
represent brief incursions of the seaway into terrestrial settings (Greb and others, 2009; Work and others, 2009). The low-sulfur and low-ash coal beds in the Pocahontas and Lee Formations in southwestern Virginia and in the Breathitt Group in eastern Kentucky may represent topogenous, planar swamp deposits that accumulated under humid climate conditions (Cecil and others, 1985).

\section{Acknowledgments}

We thank James L. Coleman, Jr., of the U.S. Geological Survey (USGS) for recognizing the scientific value of this regional geologic cross section, and for his keen interest and enthusiastic support during all stages of the investigation. We also thank Robert C. Milici (USGS) for his critical geological insights, discussions of Appalachian geology, and suggestions regarding cross section methodology. Christopher P. Garrity (USGS) significantly improved the cross section by providing a digital topographic profile based on digital elevation model (DEM) data. James L. Coleman, Jr., and Robert C. Milici, both of the USGS, and James A. Drahovzal, Stephen F. Greb, David C. Harris, and John B. Hickman, all of the Kentucky Geological Survey, improved the cross section and text through careful and thoughtful reviews.

\section{References Cited}

Al-Tawil, Aus, Wynn, T.C., and Read, J.F., 2003, Sequence response of a distal-to-proximal foreland ramp to glacio-eustacy and tectonics; Mississippian, Appalachian basin, West Virginia-Virginia, U.S.A., in Ahr, W.M., Harris, P.M., Morgan, W.A., and Somerville, I.D., eds., Permo-Carboniferous carbonate platforms and reefs: SEPM (Society for Sedi- mentary Geology) Special Publication 78 and AAPG (American Association of Petroleum Geologists) Memoir 83, p. 11-34, http://archives.datapages.com/ data/sepm_sp/SP78/Sequence_Response_of_a_Distal-to-Proximal.pdf.

Alvord, D.C., and Miller, R.L., 1972, Geologic map of the Elkhorn City quadrangle Kentucky-Virginia and part of the Harman quadrangle, Pike County, Kentucky: U.S. Geological Survey Geologic Quadrangle Map GQ-951, 1 sheet, scale 1:24,000. [Also available at http://pubs.er.usgs.gov/publication/gq951.]

Averitt, Paul, 1941, The Early Grove gas field, Scott and Washington Counties, Virginia: Virginia Geological Survey Bulletin 56, 50 p., 3 pls., https:// www.dmme.virginia.gov/commerce/ProductDetails. aspx?ProductID=2300.

Baranoski, M.T., 2002, Structure contour map on the Precambrian unconformity surface in Ohio and related basement features: Ohio Division of Geological Survey [Petroleum Geology] Map PG-23, 18-p. text, 1 sheet, scale 1:500,000, on CD-ROM, http:// www2.ohiodnr.com/portals/geosurvey/PDFs/Misc State_Maps\&Pubs/Map-PG-23_2002.pdf.

Baranoski, M.T., Dean, S.L., Wicks, J.L., and Brown, V.M., 2009, Unconformity-bounded seismic reflection sequences define Grenville-age rift system and foreland basins beneath the Phanerozoic in Ohio: Geosphere, v. 5, no. 2, p. 140-151, http://geosphere. geoscienceworld.org/content/5/2/140.full.pdf + html.

Barnaby, R.J., and Read, J.F., 1990, Carbonate ramp to rimmed shelf evolution; Lower to Middle Cambrian continental margin, Virginia Appalachians: Geological Society of America Bulletin, v. 102, no. 3, p. 391-404, http://gsabulletin.gsapubs.org/ content/102/3/391.full.pdf+html?sid=878a476f-6bf1 4db1-8c3a-2e7d68086c0e.
Bartlett, C.S., Jr., and Webb, H.W., 1971, Geology of the Bristol and Wallace quadrangles, Virginia: Virginia Division of Mineral Resources Report of Investigations 25, 93 p., 1 pl., scale 1:24,000, http:// www.dmme.virginia.gov/commercedocs/RI_25.pdf.

Beardsley, R.W., and Cable, M.S., 1983, Overview of the evolution of the Appalachian basin: Northeastern Geology, v. 5, no. 3-4, p. 137-145.

Bergstrom, S.M., and Carnes, J.B., 1985, Conodont biostratigraphy of the Lower Ordovician Chickamauga Group at Thorn Hill and Evans Ferry, in Walker, K.R., ed., The geologic history of the Thorn Hill Paleozoic section (Cambrian-Mississippian), eastern Tennessee: University of Tennessee Department of Geological Sciences Studies in Geology 10, p. 51-59.

Black, D.F.B., 1964, Geology of the Versailles quadrangle, Kentucky: U.S. Geological Survey Geologic Quadrangle Map GQ-325, 1 sheet, scale 1:24,000.

[Also available at http://pubs.er.usgs.gov/publication/ gq325.]

Black, D.F.B., 1967, Geology of the Coletown quadrangle, east-central Kentucky: U.S. Geological Survey Geologic Quadrangle Map GQ-644, 1 sheet, scale 1:24,000. [Also available at http://pubs.er.usgs.gov/ publication/gq644.]

Black, D.F.B., 1968, Geologic map of the Ford quadrangle, central Kentucky: U.S. Geological Survey Geologic Quadrangle Map GQ-764, 1 sheet, scale $1: 24,000$. [Also available at http://pubs.er.usgs.gov/ publication/gq764.]

Black, D.F.B., 1974, Geologic map of the Winchester quadrangle, Clark and Madison Counties, Kentucky: U.S. Geological Survey Geologic Quadrangle Map GQ-1159, 1 sheet, scale 1:24,000. [Also available at http://pubs.er.usgs.gov/publication/gq1159.] 
Black, D.F.B., 1989, Tectonic evolution in central and eastern Kentucky; A multidisciplinary study of surface and subsurface structure: U.S. Geological Survey Open-File Report 89-106, 149 p., 12 pls. in pocket. [Also available at http://pubs.er.usgs.gov/ publication/ofr89106.]

Bond, G.C., Kominz, M.A., and Grotzinger, J.P., 1988, Cambro-Ordovician eustasy; Evidence from geophysical modelling of subsidence in Cordilleran and Appalachian passive margins, in Kleinspehn, K.L., and Paola, Chris, eds., New perspectives in basin analysis: New York, Springer-Verlag, p. 129-160.

Boswell, Ray, 1996, Play UDs; Upper Devonian black shales, in Roen, J.B., and Walker, B.J., eds., The atlas of major Appalachian gas plays: West Virginia Geological and Economic Survey Publication V-25, p. 93-99, http://www.wvgs.wvnet.edu/wvges2/publications/PubCat_Details.aspx?PubCatID=V-25.

Boswell, Ray, Heim, L.R., Wrightstone, G.R., and Donaldson, Alan, 1996, Play Dvs; Upper Devonian Venango sandstones and siltstones, in Roen, J.B., and Walker, B.J., eds., The atlas of major Appalachian gas plays: West Virginia Geological and Economic Survey Publication V-25, p. 63-69, http://www. wvgs.wvnet.edu/wvges2/publications/PubCat Details.aspx?PubCatID=V-25.

Bova, J.A., and Read, J.F., 1987, Incipiently drowned facies within a cyclic peritidal ramp sequence, Early Ordovician Chepultepec interval, Virginia Appalachians: Geological Society of America Bulletin, v. 98 , no. 6, p. 714-727, http://gsabulletin.gsapubs. org/content $/ 98 / 6 / 714$. full.pdf + html? sid $=5 \mathrm{~d} 25 \mathrm{ab} 4 \mathrm{~b}$ 5566-48a5-90de-cfff2716e76c.

Brett, C.E., Goodman, W.M., and LoDuca, S.T., 1990, Sequences, cycles, and basin dynamics in the Silurian of the Appalachian foreland basin: Sedimentary Geology, v. 69, no. 3-4, p. 191-244, http://www. sciencedirect.com/science/journal/00370738/69/3.
Brett, C.E., Tepper, D.H., Goodman, W.M., LoDuca, S.T., and Eckert, Bea-Yeh, 1995, Revised stratigraphy and correlations of the Niagaran Provincial Series (Medina, Clinton, and Lockport Groups) in the type area of western New York: U.S. Geological Survey Bulletin 2086, 66 p. [Also available at http:// pubs.er.usgs.gov/publication/b2086.]

Brezinski, D.K., Cecil, C.B., and Skema, V.W., 2010, Late Devonian glacigenic and associated facies from the central Appalachian basin, eastern United States: Geological Society of America Bulletin, v. 122, no. 1-2, p. 265-281, http://gsabulletin.gsapubs.org/ content/122/1-2/265.full.pdf + html? sid=c9a1c21832f1-4ac8-8cef-247f07f8d9b9.

Bruner, K.R., 1988, Sedimentary facies of the Lower Devonian Oriskany Sandstone, Greenbrier County, West Virginia, in Smosna, Richard, organizer, A walk through the Paleozoic of the Appalachian basin; A core workshop presented at the American Association of Petroleum Geologists Eastern Section meeting, Charleston, West Virginia, September 13, 1988: Charleston, West Virginia, Appalachian Geological Society, p. 38-47.

Butts, Charles, 1940, Geology of the Appalachian Valley in Virginia, pt. I: Virginia Geological Survey Bulletin 52, 568 p., https://www.dmme.virginia.gov/ commerce/ProductDetails.aspx? productID $=1428$.

Byrd, W.J., Weinberg, E.L., and Yochelson, E.L., 1973, Salterella in the Lower Cambrian Shady Dolomite of southwestern Virginia: American Journal of Science, v. 273-A (Cooper Volume), p. 252-260, http://earth. geology.yale.edu/ ajs/1973/ajs_273A_11.pdf/252.pdf.

Calvert, W.L., 1962, Sub-Trenton rocks from Lee County, Virginia, to Fayette County, Ohio: Ohio Department of Natural Resources, Division of Geological Survey Report of Investigations 45, 57 p., $1 \mathrm{pl}$.
Calvert, W.L., 1964, Cambrian erosional remnants yield oil in central Ohio: World Oil, v. 158, no. 4, p. 78, $80,82,84$.

Cannon, W.F., Green, A.G., Hutchinson, D.R., Lee, M.W., Milkereit, Bernd, Behrendt, J.C., Halls, H.C., Green, J.C., Dickas, A.B., Morey, G.B., Sutcliffe, R.H., and Spencer, Carl, 1989, The North American midcontinent rift beneath Lake Superior from GLIMPCE seismic reflection profiling: Tectonics, v. 8 , no. 2, p. 305-332, http://onlinelibrary.wiley. com/doi/10.1029/TC008i002p00305/pdf.

Cardwell, D.H., Erwin, R.B., and Woodward, H.P., comps., 1968, Geologic map of West Virginia: Morgantown, West Virginia, West Virginia Geological and Economic Survey, 2 sheets, scale 1:250,000 http://www.wvgs.wvnet.edu/wvges2/publications/ PubCat_DetailSearch.aspx.

Carney, Cindy, and Smosna, Richard, 1989, Carbonate deposition in a shallow marine gulf, the Mississippian Greenbrier Limestone of the central Appalachian basin: Southeastern Geology, v. 30, no. 1, p. 25-48.

Castle, J.W., 2001, Appalachian basin stratigraphic response to convergent-margin structural evolution: Basin Research, v. 13, no. 4, p. 397-418, http://onlinelibrary.wiley.com/doi/10.1046/j.0950091x.2001.00157.x/pdf.

Cecil, C.B., 2004a, Eolian dust and the origin of Devonian cherts in the Appalachian basin, USA [abs.]: Geological Society of America Abstracts with Programs, v. 36, no. 2, p. 118, https://gsa.confex.com/ gsa/2004NE/finalprogram/abstract_69642.htm.

Cecil, C.B., 2004b, Eolian dust and the origin of sedimentary chert: U.S. Geological Survey Open-File Report 2004-1098, 15 p. [Also available at http:// pubs.er.usgs.gov/publication/ofr20041098.] 
Cecil, C.B., Brezinski, D.K., and Dulong, Frank, 2004, The Paleozoic record of changes in global climate and sea level; Central Appalachian basin, trip 3 of Southworth, Scott, and Burton, William, eds., Geology of the National Capital region-Field trip guidebook: U.S. Geological Survey Circular 1264, p. 77-135. [Also available at http://pubs.usgs.gov/ circ/2004/1264/.]

Cecil, C.B., Stanton, R.W., Neuzil, S.G., Dulong, F.T., Ruppert, L.F., and Pierce, B.S., 1985, Paleoclimate controls on late Paleozoic sedimentation and peat formation in the central Appalachian basin (U.S.A.): International Journal of Coal Geology, v. 5, no. 2, p. 195-230, http://www.researchgate.net/publication/248516794_Paleoclimate controls on late paleozoic_sedimentation_and_peat_formation_in_ the_central_appalachian_basin_(U.S.A.).

Chesnut, D.R., Jr., 1992, Stratigraphic and structural framework of the Carboniferous rocks of the central Appalachian basin in Kentucky: Kentucky Geological Survey Bulletin 3, ser. 11, 42 p., 8 pls.

Clark, J.E., Bonura, D.K., Miller, C., and Fischer, F.T., 2005, Demonstration of presence and size of a $\mathrm{CO}_{2}$-rich fluid phase after $\mathrm{HCl}$ injection in carbonate rock, chap. 33 of Tsang, Chin-Fu, and Apps, J.A., eds., Underground injection science and technology: Amsterdam, Elsevier, p. 451-458.

Colton, G.W., 1961, Geologic summary of the Appalachian basin, with reference to the subsurface disposal of radioactive waste solutions: U.S. Geological Survey Report TEI-791, 120 p., 19 pls. in pocket. [Prepared on behalf of the U.S. Atomic Energy Commission.]

Colton, G.W., 1970, The Appalachian basin-Its depositional sequences and their geologic relationships, in Fisher, G.W., Pettijohn, F.J., Reed, J.C., Jr., and Weaver, K.N., eds., Studies of Appalachian geology; Central and southern: New York, Wiley Interscience Publishers, p. 5-47.
Cooper, B.N., 1945, Industrial limestones and dolomites in Virginia: Clinch Valley District: Virginia Geological Survey Bulletin 66, 259 p., https://www. dmme.virginia.gov/commerce/ProductDetails. aspx?productID=2594.

Cooper, B.N., 1966, Geology of the salt and gypsum deposits in the Saltville area, Smyth and Washington Counties, Virginia, in Rau, J.L., ed., [Proceedings of the] 2nd Salt Symposium, 1965, Cleveland, Ohio: Cleveland, Ohio, Northern Ohio Geologic Society, v. 1 (Geology, geochemistry, mining), p. 11-35.

Cooper, B.N., 1968, Profile of the folded Appalachians of West Virginia: UMR (University of Missouri at Rolla) Journal, v. 1, p. 27-64.

Cressman, E.R., 1964, Geologic map of the Tyrone quadrangle, Kentucky: U.S. Geological Survey Geologic Quadrangle Map GQ-303, 1 sheet, scale 1:24,000. [Also available at http://pubs.er.usgs.gov/ publication/gq303.]

Cressman, E.R., 1965, Geologic map of the Keene quadrangle, central Kentucky: U.S. Geological Survey Geologic Quadrangle Map GQ-440, 1 sheet, scale 1:24,000. [Also available at http://pubs.er.usgs. gov/publication/gq440.]

Cressman, E.R., 1973, Lithostratigraphy and depositional environments of the Lexington Limestone (Ordovician) of central Kentucky: U.S. Geological Survey Professional Paper 768, 61 p. [Also available at http://pubs.er.usgs.gov/publication/pp768.]

Cressman, E.R., 1975a, Geologic map of the Shelbyville quadrangle, Shelby County, Kentucky: U.S. Geological Survey Geologic Quadrangle Map GQ-1258, 1 sheet, scale 1:24,000. [Also available at http://pubs.er.usgs.gov/publication/gq1258.]

Cressman, E.R., 1975b, Geologic map of the Waddy quadrangle, central Kentucky: U.S. Geological Sur- vey Geologic Quadrangle Map GQ-1255, 1 sheet, scale 1:24,000. [Also available at http://pubs.er.usgs. gov/publication/gq1255.]

Cressman, E.R., 1981, Surface geology of the Jeptha Knob cryptoexplosion structure, Shelby County, Kentucky: U.S. Geological Survey Professional Paper 1151-B, 16 p., 1 pl. in pocket. [Also available at http://pubs.er.usgs.gov/publication/pp1151B.]

Cressman, E.R., and Noger, M.C., 1976, Tidal-flat carbonate environments in the High Bridge Group (Middle Ordovician) of central Kentucky: Kentucky Geological Survey Report of Investigations 18, ser. 10, 15 p., 1 pl., http://kgs.uky.edu/kgsweb/olops/ pub/kgs/XRI18reduce.pdf.

Culotta, R.C., Pratt, T., and Oliver, J., 1990, A tale of two sutures: COCORP's deep seismic surveys of the Grenville province in the eastern U.S. midcontinent: Geology, v. 18, no. 7, p. 646-649, http:// geology.geoscienceworld.org/content/18/7/646. full.pdf + html? sid=f61242d8-b044-4c20-997c6f0b47b516e6.

Currie, M.T., and MacQuown, W.C., 1984, Subsurface stratigraphy of the Corniferous (Silurian-Devonian) of eastern Kentucky, in Luther, M.K., ed., Proceedings of the Technical Sessions; Kentucky Oil and Gas Association, 45th Annual Meeting, June 10-12, 1981, Kentucky Geological Survey Special Publication 11 , ser. 11, p. 1-21.

Denison, R.E., Lidiak, E.G., Bickford, M.E., and Kisvarsanyi, E.B., 1984, Geology and geochronology of Precambrian rocks in the central interior region of the United States, in Harrison, J.E. and Peterman, Z.E., eds., Correlation of Precambrian rocks of the United States and Mexico: U.S. Geological Survey Professional Paper 1241-C, p. C1-C20, 1 pl. in pocket. [Also available at http://pubs.er.usgs.gov/ publication/pp1241C.] 
Denkler, K.E., and Harris, A.G., 1988a, Conodontbased determination of the Silurian-Devonian boundary in the Valley and Ridge province, northern and central Appalachians: U.S. Geological Survey Bulletin 1837-B, p. B1-B13. [Also available at http:// pubs.er.usgs.gov/publication/b1837.]

Denkler, K.E., and Harris, A.G., 1988b, Homeognathodus peniculus (Conodonta), a new earliest Pridolian index species, and the Ludlovian-Pridolian boundary in the central Appalachian basin: U.S. Geological Survey Bulletin 1837-C, p. C1-C8. [Also available at http://pubs.er.usgs.gov/publication/b1837.]

Dennison, J.M., and Head, J.W., 1975, Sealevel variations interpreted from the Appalachian basin Silurian and Devonian: American Journal of Science, v. 275, no. 10, p. 1089-1120, http://www.ajsonline.org/content/275/10/1089. citation.

Derby, J.R., 1965, Paleontology and stratigraphy of the Nolichucky Formation in southwest Virginia and northeast Tennessee: Blacksburg, Virginia, Virginia Polytechnic Institute and State University, Ph.D. dissertation, 569 p., 28 pls.

Dever, G.R., Jr., 1986, Mississippian reactivation along the Irvine-Paint Creek fault system in the Rome trough, east-central Kentucky: Southeastern Geology, v. 27, no. 2, p. 95-105.

de Witt, Wallace, Jr., Roen, J.B., and Wallace, L.G., 1993, Stratigraphy of Devonian black shales and associated rocks in the Appalachian basin, Chap. B of Roen, J.B., and Kepferle, R.C., eds., Petroleum geology of the Devonian and Mississippian black shale of eastern North America: U.S. Geological Survey Bulletin 1909, p. B1-B57, 11 pls. [Also available at http://pubs.er.usgs.gov/publication/b1909.]

Diecchio, R.J., 1985, Post-Martinsburg Ordovician stratigraphy of Virginia and West Virginia: Virginia Division of Mineral Resources Publication 57, 77 p.,
https://www.dmme.virginia.gov/commerce/PublicationCatList.aspx CategoryId $=32 \&$ TblPcCode $=5 \&$ se lection $=4$.

Diecchio, R.J., 1991, Taconic sedimentary basins of the Appalachians, in Barnes, C.R., and Williams, S.H., eds., Advances in Ordovician geology: Geological Survey of Canada Paper 90-9, p. 225-234, http:// ftp2.cits.rncan.gc.ca/pub/geott/ess_pubs/132/132172/ pa_90_09.pdf.

Diecchio, R.J., Jones, S.E., and Dennison, J.M., 1984, Oriskany Sandstone-Regional stratigraphic relationships and production trends: West Virginia Geological and Economic Survey Map WV-17, 8 pls., scale 1:2,000,000, http://www.wvgs. wvnet.edu/wvges2/publications/PubCat_Details. aspx?PubCatID=MAP-WV17.

Dillman, S.B., and Ettensohn, F.R., 1980, Structure contour map on the base of the Ohio Shale in eastern Kentucky: U.S. Department of Energy [DOE] Morgantown Energy Technology Center, Eastern Gas Shale Project Series No. 507, 1 sheet, scale 1:307,000. [Prepared under contract number EY-76-C-05-5202.]

Donaldson, A.C., Heald, Milton, and Warshauer, Steven, 1988, Cambrian rocks of the Rome trough in West Virginia; Cores from Mingo and Wayne Counties, in Smosna, R., organizer, A walk through the Paleozoic of the Appalachian basin; A core workshop presented at the American Association of Petroleum Geologists Eastern Section meeting, Charleston, West Virginia, September 13, 1988: Charleston, West Virginia, Appalachian Geological Society, p. 6-18.

Donnell, J.R., and Johnston, J.E., 1963, Geology of the Quicksand quadrangle, Kentucky: U.S. Geological Survey Geologic Quadrangle Map GQ-240, 1 sheet, scale 1:24,000. [Also available at http://pubs.er.usgs. gov/publication/gq240.]
Dorobek, S.L., and Read, J.F., 1986, Sedimentology and basin evolution of the Siluro-Devonian Helderberg Group, central Appalachians: Journal of Sedimentary Petrology, v. 56, no. 5, p. 601-613.

Dorsch, Joachim, Bambach, R.K., and Driese, S.G., 1994, Basin-rebound origin for the "Tuscarora unconformity" in southwestern Virginia and its bearing on the nature of the Taconic orogeny: American Journal of Science, v. 294, no. 2, p. 237-255, http:// www.ajsonline.org/content/294/2.toc.

Dorsch, Joachim, and Driese, S.G., 1995, The Taconic foredeep as sediment sink and sediment exporter; Implications for the origin of the white quartzarenite blanket (Upper Ordovician-lower Silurian) of the central and southern Appalachians: American Journal of Science, v. 295, no. 2, p. 201-243, http://www. ajsonline.org/content/295/2.toc.

Drahovzal, J.A., Harris, D.C., Wickstrom, L.H., Walker, Dan, Baranoski, M.T., Keith, Brian, and Furer, L.C., 1992, The East Continent Rift basin; A new discovery: Kentucky Geological Survey Special Publication 18, ser. 11, 25 p.

Drahovzal, J.A., and Noger, M.C., 1995, Preliminary map of the structure of the Precambrian surface in eastern Kentucky: Kentucky Geological Survey Map and Chart Series 8, ser. 11, 1 sheet, scale 1:500,000, 9-p. text, http://kgs.uky.edu/kgsweb/ pubs/pubsearch.asp.

Drake, A.A., Jr., Sinha, A.K., Laird, Jo, and Guy, R.E., 1989, The Taconic orogen, in Hatcher, R.D., Jr., Thomas, W.A., and Viele, G.W., eds., The Appalachian-Ouachita orogen in the United States, v. F-2 of The geology of North America: Boulder, Colo., Geological Society of America, p. 101-177, http://rock. geosociety.org/Store/detail.aspx?id=DNAGGNAF2. 
Englund, K.J., 1979, The Mississippian and Pennsylvanian (Carboniferous) Systems in the United StatesVirginia: U.S. Geological Survey Professional Paper 1110-C, p. C1-C21. [Also available at http://pubs. usgs.gov/pp/1110a-1/report.pdf.]

Englund, K.J., Gillespie, W.H., Cecil, C.B., Windolph, J.F., Jr., and Crawford, T.J., 1985, Characteristics of the Mississippian-Pennsylvanian boundary and associated coal-bearing rocks in the southern Appalachians; Guidebook for the Geological Society of America Annual Meeting, Orlando, Florida, October 28-31, 1985: U.S. Geological Survey Open-File Report 85-577, 84 p. [Also available at http://pubs. er.usgs.gov/publication/ofr85577.]

Englund, K.J., Windolph, J.F., Jr., and Thomas, R.E., 1986, Origin of thick, low-sulphur coal in the Lower Pennsylvanian Pocahontas Formation, Virginia and West Virginia, in Lyons, P.C., and Rice, C.L., eds., Paleoenvironmental and tectonic controls in coal-bearing basins in the United States: Geological Society of America Special Paper 210, p. 49-61, http://specialpapers.gsapubs.org/content/210/49. full.pdf + html? sid=31 ec6055-d5d2-4e7d-86171 b7383bdc6e5.

Englund, K.J., Gillespie, W.H., Johnson, P.L., and Pfefferkorn, H.W., 1986, Depositional model for Upper Mississippian and Lower Pennsylvanian rocks of southwestern Virginia, in McDowell, R.C., and Glover, Lynn, III, Rodgers, John, Bambach, R.K., Gray, D.R., eds., The Lowry volume; Studies in Appalachian geology: Virginia Polytechnic Institute and State University, Department of Geological Science Memoir 3, p. 37-45.

Englund, K.J., and Thomas, R.E., 1990, Late Paleozoic depositional trends in the central Appalachian basin: U.S. Geological Survey Bulletin 1839-F, p. F1-F19. [Also available at http://pubs.er.usgs.gov/publication/ b1839F.]
Ettensohn, F.R., 1991, Flexural interpretation of relationships between Ordovician tectonism and stratigraphic sequences, central and southern Appalachians, U.S.A., in Barnes, C.R., and Williams, S.H., eds., Advances in Ordovician geology: Geological Survey of Canada Paper 90-9, p. 213-224, http:// ftp2.cits.rncan.gc.ca/pub/geott/ess_pubs/132/132172/ pa_90_09.pdf.

Ettensohn, F.R., ed., 1992a, Changing interpretations of Kentucky geology; Layer-cake, facies, flexure, and eustacy: Ohio Geological Survey Miscellaneous Report No. 5, 184 p., http://geosurvey.ohiodnr.gov/ publications-maps-data/miscellaneous-items/miscreports-mr.

Ettensohn, F.R., 1992b, Regressive facies in the upper Lexington Limestone; Tanglewood-Millersburg relationships, in Ettensohn, F.R., ed., Changing interpretations of Kentucky geology; Layer-cake, facies, flexure, and eustacy: Ohio Geological Survey Miscellaneous Report No. 5, p. 62-66, http://geosurvey. ohiodnr.gov/publications-maps-data/miscellaneousitems/misc-reports-mr.

Ettensohn, F.R., 1992c, Paleosols and restricted Slade carbonates west of the Waverly arch apical island, in Ettensohn, F.R., ed., Changing interpretations of Kentucky geology; Layer-cake, facies, flexure, and eustacy: Ohio Geological Survey Miscellaneous Report No. 5, p. 88-100, http://geosurvey.ohiodnr. gov/publications-maps-data/miscellaneous-items/ misc-reports-mr.

Ettensohn, F.R., 1994, Tectonic control on formation and cyclicity of major Appalachian unconformities and associated stratigraphic sequences, in Dennison, J.M., and Ettensohn, F.R., eds., Tectonic and eustatic controls on sedimentary cycles: SEPM (Society for Sedimentary Geology) Concepts in Sedimentology and Paleontology, v. 4, p. 217-242, http://cs.sepmonline.org/content/sepcotec/1/local/ front-matter.pdf.

Ettensohn, F.R., 2009, The Mississippian of the Appalachian basin, in Greb, S.F., and Chesnut, D.R., Jr., eds., Carboniferous geology and biostratigraphy of the Appalachian basin: Kentucky Geological Survey Special Publication 10, ser. 12, p. 22-31, http://kgs. uky.edu/kgsweb/pubs/pubsearch.asp.

Ettensohn, F.R., Johnson, Walter, Stewart, Alex, Solis, Mike, and White, Tina, 2002, Middle and Upper Mississippian stratigraphy and depositional environments in east-central Kentucky; The New Bighill exposure, in Ettensohn, F.R., and Smath, M.L., eds., Guidebook for geology field trips in Kentucky and adjacent areas; 2002 Joint Meeting of the NorthCentral Section and Southeastern Section of the Geological Society of America, Lexington, Kentucky, April 3-5, 2002: Lexington, Kentucky, University of Kentucky, p. 14-34.

Ettensohn, F.R., Greb, S.F., Chesnut, D.R., Jr., Harris, D.C., Mason, C.E., Eble, C.F., Howell, P.D., Watson, A.E., and Johnson, W.K., 2002, Mississippian stratigraphy, depositional environments, and tectonic framework of the central Appalachian basin, eastern Kentucky, U.S.A., in Hills, L.V., Henderson, C.M., and Bamber, E.W., eds., Carboniferous and Permian of the World: Canadian Society of Petroleum Geologists Memoir 19, p. 22-40.

Ettensohn, F.R., Miller, M.L, Dillman, S.B., Elam, T.D., Geller, K.L., Swager, D.R., Markowitz, G., Woock, R.D., and Barron, L.S., 1988, Characterization and implications of the Devonian-Mississippian black-shale sequence, eastern and central Kentucky, U.S.A.; Pycnoclines, transgresson, regression, and tectonism, in McMillan, N.J., Embry, A.F., and Glass, D.J., eds., Devonian of the world: Canadian Society of Petroleum Geologists Memoir 14, no. 2, p. 323-345. 
Ettensohn, F.R., Rice, C.L., Dever, G.R., Jr., and Chesnut, D.R., 1984, Slade and Paragon Formations; New stratigraphic nomenclature for Mississippian rocks along the Cumberland Escarpment in Kentucky: U.S. Geological Survey Bulletin 1605-B, 37 p. [Also available at http://pubs.usgs.gov/bul/1605b/report. pdf.]

Evans, N.H., and Troensegaard, K.W., 1991, Geology of St. Paul and Carbo quadrangles, Virginia: Virginia Division of Mineral Resources Publication 106, 2 pls., scale 1:24,000, https:/www.dmme.virginia.gov/commerce/ProductDetails.aspx?productID $=2261$.

Faill, R.T., 1997a, A geologic history of the northcentral Appalachians, Part 1; Orogenesis from the Mesoproterozoic through the Taconic orogeny: American Journal of Science, v. 297, no. 6, p. 551-619, http://www.ajsonline.org/content/297/6.toc.

Faill, R.T., 1997b, A geologic history of the northcentral Appalachians, Part 2; The Appalachian basin from the Silurian through the Carboniferous: American Journal of Science, v. 297, no. 7, p. 729-761, http://www.ajsonline.org/content/297/7.toc.

Faill, R.T., 1998, A geologic history of the north-central Appalachians, Part 3; The Alleghany orogeny: American Journal of Science, v. 298, no. 2, p. 131-179, http://www.ajsonline.org/content/298/2.toc.

Fenneman, N.M., 1975, Physical divisions of the United States; Set of one hundred topographic maps illustrating specified physiographic features: U.S. Geological Survey map, scale 1:1,700,000, 1 sheet. [Prepared in cooperation with the physiographic committee of the U.S. Geological Survey.]

Filer, J.K., 2002, Late Frasnian sedimentation cycles in the Appalachian basin-Possible evidence for high frequency sea-level changes: Sedimentary Geology, v. 154, nos. 1-2, p. 31-52, http://www.sciencedirect. com/science/article/pii/S0037073802001598.
Filer, J.K., 2003, Stratigraphic evidence for a Late Devonian possible back-bulge basin in the Appalachian basin, United States: Basin Research, v. 15, no. 3, p. 417-429, http://onlinelibrary.wiley.com/ doi/10.1046/j.1365-2117.2003.00213.x/abstract.

Freeman, L.B., 1951, Regional aspects of Silurian and Devonian stratigraphy in Kentucky: Kentucky Geological Survey Bulletin 6, ser. 9, 575 p., http://kgs. uky.edu/kgsweb/pubs/pubsearch.asp.

Freeman, L.B., 1953, Regional subsurface stratigraphy of the Cambrian and Ordovician in Kentucky and vicinity: Kentucky Geological Survey Bulletin 12, ser. 9, 352 p., 10 pls., http://kgs.uky.edu/kgsweb/ pubs/pubsearch.asp.

Goodmann, P.T., 1992, A Paleozoic subsidence history of the autochthonous Appalachian basin in Kentucky, in Ettensohn, F.R., ed., Changing interpretations of Kentucky geology; Layer-cake, facies, flexure, and eustacy: Ohio Geological Survey Miscellaneous Report No. 5, p. 12-19, http://geosurvey.ohiodnr. gov/publications-maps-data/miscellaneous-items/ misc-reports-mr

Gradstein, Felix, Ogg, James, and Smith, Alan, 2004, A geologic time scale 2004: New York, N.Y., Cambridge University Press, 589 p., 1 pl. in pocket.

Gray, H.H., 1972, Lithostratigraphy of the Maquoketa Group (Ordovician) in Indiana: Indiana Geological Survey Special Report 7, $31 \mathrm{p}$

Greb, S.F., and Chesnut, D.R., Jr., 1996, Lower and lower Middle Pennsylvanian fluvial to estuarine deposition, central Appalachian basin; Effects of eustacy, tectonics, and climate: Geological Society of America Bulletin, v. 108, no. 3, p. 303-317, http://gsabulletin.gsapubs.org/content/108/3/303. full.pdf + html? sid=f08461b2-e1da-4d04-95d1748 b88edcc 13 .
Greb, S.F., Chesnut, D.R., Jr., and Eble, C.F., 2004, Temporal changes in coal-bearing depositional sequences (Lower and Middle Pennsylvania) of the central Appalachian basin, U.S.A., in Pashin, J.C., and Gastaldo, R.A., eds., Sequence stratigraphy, paleoclimate, and tectonics of coal-bearing strata: American Association of Petroleum Geologists Studies in Geology 51, p. 89-120, http://archives. datapages.com/data/specpubs/study51/Chapter5/ IMAGES/CHAPTER5.PDF.

Greb, S.F., Chesnut, D.R., Jr., Eble, C.F., and Blake, B.M., 2009, The Pennsylvanian of the Appalachian basin, in Greb, S.F., and Chesnut, D.R., Jr., eds., Carboniferous geology and biostratigraphy of the Appalachian basin: Kentucky Geological Survey Special Publication 10, ser. 12, p. 32-45, http://kgs. uky.edu/kgsweb/pubs/pubsearch.asp.

Greb, S.F., Bowersox, J.R., Solis, M.P., Harris, D.C., Riley, R.A., Rupp, J.A., Kelley, M., and Gupta, N., 2012, Extended abstract-Ordovician Knox carbonates and sandstones of the eastern midcontinent; Potential geologic carbon storage reservoirs and seals, in Derby, J., Fritz, R., Longacre, S., Morgan, W., and Sternbach, C., eds., The great American carbonate bank; The geology and economic resources of the Cambrian-Ordovician Sauk megasequence of Laurentia: AAPG Memoir 98, p. 469a-478a.

Hamilton-Smith, Terence, 1993, Gas exploration in the Devonian shales of Kentucky: Kentucky Geological Survey Bulletin 4, ser. 11, 31 p., http://kgs.uky.edu/ kgsweb/pubs/pubsearch.asp.

Hardeman, W.D., 1966, Geologic map of Tennessee: Tennessee Division of Geology, 4 sheets, scale 1:250,000.

Harland, W.B., Armstrong, R.L., Cox, A.V., Craig, L.E., Smith, A.G., and Smith, D.G., 1990, A geologic time scale 1989: Cambridge, United Kingdom, Cambridge University Press, 263 p. 
Harper, J.A., and Patchen, D.G., 1996, Play Dos; Lower Devonian Oriskany Sandstone structural play, in Roen, J.B., and Walker, B.J., eds., The atlas of major Appalachian gas plays: West Virginia Geological and Economic Survey Publication V-25, p. 109-117,

http://www.wvgs.wvnet.edu/wvges2/publications/ PubCat_Details.aspx?PubCatID=V-25.

Harris, A.G., and Repetski, J.E., 1982, Conodonts revise the Lower-Middle Ordovician boundary and timing of miogeoclinal events in the east-central Appalachian basin [abs.]: Geological Society of America Abstracts with Programs, v. 14, no. 5, p. 261.

Harris, D.C., and Baranoski, M.T., 1996, Play Cpk; Cambrian pre-Knox Group play, in Roen, J.B., and Walker, B.J., eds., The atlas of major Appalachian gas plays: West Virginia Geological and Economic Survey Publication V-25, p. 188-192, http:/www. wvgs.wvnet.edu/wvges $2 /$ publications/PubCat_ Details.aspx?PubCatID=V-25.

Harris, D.C., Hickman, J.B., Baranoski, M.T., Drahovzal, J.A., Avary, K.L., and Nuttall, B.C., 2004, Rome trough consortium final report and data distribution: Kentucky Geological Survey, ser. 12, Open File Report 04-06, 1 CD-ROM.

Harris, D.C., and Sparks, T.N., 2000, Regional subsurface geologic cross sections of the Mississippian System, Appalachian basin, eastern Kentucky: Kentucky Geological Survey Map and Chart Series 14 , ser. 12,14 sheets.

Harris, L.D., 1970, The Valley and Ridge and Appalachian Plateau-Structure and tectonics; Details of thin-skinned tectonics in parts of Valley and Ridge and Cumberland Plateau provinces of the southern Appalachians, in Fisher, G.W., Pettijohn, F.J., Reed, J.C., Jr., and Weaver, K.N., eds., Studies of Appalachian geology, central and southern: New York, InterScience publishers, p. 161-173.
Harris, L.D., 1973, Dolomitization model of Upper Cambrian and Lower Ordovician carbonate rocks in the eastern United States: Journal of Research of the U.S. Geological Survey, v. 1, no. 1, p. 63-78. [Also available at http://pubs.er.usgs.gov/publication/70007394.]

Harris, L.D., 1978, The eastern interior aulacogen and its relation to Devonian shale-gas production, in Wheeler, R.L., and Dean, C.S., eds., Preprints for Second Eastern Gas Shales Symposium; Morgantown, West Virginia, October, 1978: Morgantown, West Virginia, U.S. Department of Energy Morgantown Energy Technology Center, v. 1, no. METC/ SP-78/6, p. 56-72, http://www.netl.doe.gov/KMD/ Cds/disk7/disk1/EGS\%5CPreprints\%20for\%20 Second\%20Eastern\%20Gas\%20Shale\%20Symposium $\% 20$ Vol\%20I\%20\&\%20Vol.pdf.

Harris, L.D., and Milici, R.C., 1977, Characteristics of thin-skinned style of deformation in the southern Appalachians, and potential hydrocarbon traps: U.S. Geological Survey Professional Paper 1018, 40 p., 9 pls. in pocket. [Also available at http://pubs. er.usgs.gov/publication/pp1018.]

Hatcher, R.D., Jr., Thomas, W.A., Geiser, P.A., Snoke A.W., Mosher, Sharon, and Wiltschko, D.W., 1989, Alleghanian orogen, in Hatcher, R.D., Jr., Thomas, W.A., and Viele, G.W., eds., The AppalachianOuachita orogen in the United States; v. F-2 of The geology of North America: Boulder, Colo., Geological Society of America, p. 233-318, http://rock. geosociety.org/Store/detail.aspx?id=DNAGGNAF2.

Hauser, E.C., 1993, Grenville foreland thrust belt hidden beneath the eastern U.S. midcontinent: Geology, v. 21, no. 1, p. 61-64, http://www.geo.cornell. edu/COCORP/ELLIPSE/COCORP/Publications/ Reprint\%20162.pdf.

Haynes, J.T., 1991, Stratigraphy of the Waynesboro Formation (Lower and Middle Cambrian) near
Buchanan, Botetourt County, Virginia: Virginia Division of Mineral Resources Publication 116, 22 p., https://www.dmme.virginia.gov/commerce/ProductDetails.aspx?productID=2356.

Haynes, J.T., 1992, Reinterpretation of Rocklandian (Upper Ordovician) K-bentonite stratigraphy in southwest Virginia, southeast West Virginia, and northeast Tennessee with a discussion of the conglomeratic sandstones in the Bays and Moccasin Formations: Virginia Division of Mineral Resources Publication 126, 58 p., https://www. dmme.virginia.gov/commerce/ProductDetails. aspx? productID $=2363$.

Heald, M.T., 1981, Precambrian from basement well in Mingo County, West Virginia: American Association of Petroleum Geologists Bulletin, v. 65 , no. 4 , p. 749-751, http://archives.datapages.com/data/bulletns/1980-81/images/pg/00650004/0700/07490.pdf.

Heckel, P.H., and Clayton, G., 2006, Use of the official names for the Subsystems, Series, and Stages of the Carboniferous System in international journals: Proceedings of the Geologists' Association, v. 117, pt. 4, p. 393-396.

Henika, W.S., 1989, Geology of the Virginia portion of the Harmon and Jamboree quadrangles: Virginia Division of Mineral Resources Publication 98, 1 sheet, scale 1:24,000.

Henika, W.S., 1994, Internal structure of the coalbearing portion of the Cumberland overthrust block in southwestern Virginia and adjoining areas, in Geology and mineral resources of the southwest Virginia coalfield: Virginia Division of Mineral Resources Publication 131, p. 100-120, https:// www.dmme.virginia.gov/commerce/ProductDetails. aspx? productID $=2199$. 
Hickman, J.B., 2004, Regional structure and tectonics, in Harris, D.C., Hickman, J.B., Baranoski, M.T., Drahovzal, J.A., Avary, K.L., and Nuttall, B.C., Rome trough consortium final report and data distribution: Kentucky Geological Survey, ser. 12, Open File Report 04-06, p. 2-1 to 2-10, 1 CD-ROM.

Hickman, J.B., Harris, D.C., Baranoski, M.T., and Nuttall, B.C., 2004, Regional stratigraphy and depositional history, in Harris, D.C., Hickman, J.B., Baranoski, M.T., Drahovzal, J.A., Avary, K.L., and Nuttall, B.C., Rome trough consortium final report and data distribution: Kentucky Geological Survey, ser. 12, Open File Report 04-06, p. 3-1 to 3-17, $1 \mathrm{CD}-\mathrm{ROM}$.

Hickman, J.B., Harris, D.C., Drahovzal, J.A., and Lake, P.D., 2006, Geologic structure and seismic analysis, chap. 2 of Patchen, D.G., Hickman, J.B., Harris, D.C., Drahovzal, J.A., Lake, P.D., Smith, L.B., Nyahay, Richard, Schulze, Rose, Riley, R.A., Baranoski, M.T., Wickstrom, L.H., Laughrey, C.D., Kostelnik, Jaime, Harper, J.A., Avary, K.L., Bocan, John, Hohn, M.Ed., and McDowell, Ronald, A geologic play book for Trenton-Black River Appalachian basin exploration: Morgantown, West Virginia, U.S. Department of Energy National Energy Technology Laboratory, p. 39-63, 8 oversize pls., 1 CD-ROM (prepared by a consortium under DOE award DE-FC26-03NT41856.)

Hinrichs, E.N., and Ping, R.G., 1978, Geologic map of the Wayland quadrangle, Knott and Floyd Counties, Kentucky: U.S. Geological Survey Geologic Quadrangle Map GQ-1451, scale 1:24,000. [Also available at http://pubs.er.usgs.gov/publication/gq1451.]

Hoppe, W.J., Montgomery, C.W., and Van Schmus, W.R., 1983, Age and significance of Precambrian basement samples from northern Illinois and adjacent states: Journal of Geophysical Research, v. 88, no. B9, p. 7276-7286, http://onlinelibrary.wiley.com/ doi/10.1002/jgrb.v88.B9/issuetoc.

Huff, W.D., and Kolata, D.R., 1990, Correlation of the Deicke and Millbrig K-bentonites between the Mississippi Valley and the southern Appalachians: American Association of Petroleum Geologists Bulletin, v. 74, no. 11, p. 1736-1747, http://archives. datapages.com/data/bulletns/1990-91/images/ pg/00740011/0000/17360.pdf.

Huff, W.D., Bergström, S.M., and Kolota, D.R., 1992, Gigantic Ordovician volcanic ash fall in North America and Europe; Biological, tectomagmatic, and event-stratigraphic significance: Geology, v. 20, no. 10 , p. $875-878$, http://geology.geoscienceworld. org/content $/ 20 / 10 / 875$.full.pdf + html? sid $=41 \mathrm{a} 6 \mathrm{~b} 7 \mathrm{~b} 7$ 1500-4748-b42a-07896aa72a51.

Humphreys, Matthew, and Watson, A.E., 1996, Play Osp; Middle Ordovician St. Peter Sandstone, in Roen, J.B., and Walker, B.J., eds., The atlas of major Appalachian gas plays: West Virginia Geological and Economic Survey Publication V-25, p. 177-180, http:/www.wvgs.wvnet.edu/wvges2/publications/ PubCat_Details.aspx?PubCatID=V-25.

International Commission on Stratigraphy, 2014, International chronostratigraphic chart (ver. 2014/02): International Commission on Stratigraphy, http://www.stratigraphy.org/ICSchart/ChronostratChart2014-02.pdf.

Janssens, Adriaan, 1973, Stratigraphy of the Cambrian and Lower Ordovician rocks in Ohio: Ohio Division of Geological Survey Bulletin 64, 197 p., 9 pls. in pocket.

Jenkins, E.C., 1967, Geologic map of the Millard quadrangle, Pike County, Kentucky: U.S. Geological Survey Geologic Quadrangle Map GQ-659, scale 1:24,000. [Also available at http://pubs.er.usgs.gov/ publication/gq659.]
Kammer, T.W., and Bjerstedt, T.W., 1986, Stratigraphic framework of the Price Formation (Upper DevonianLower Mississippian) in West Virginia: Southeastern Geology, v. 27, no. 1, p. 13-33.

Keller, G.R., Ammerman, M.L., and Bland, A.E., 1981, A geophysical and tectonic study of east-central Kentucky with emphasis on the Rome trough, in Luther, M.K., ed., Proceedings of the Technical Sessions; Kentucky Oil and Gas Association, 39th and 40th Annual Meetings, 1975 and 1976, Kentucky Geological Survey Special Publication 4, ser. 11, p. 41-48.

Kepferle, R.C., 1974a, Geologic map of parts of the Jeffersonville, New Albany, and Charlestown quadrangles, Kentucky-Indiana: U.S. Geological Survey Geologic Quadrangle Map GQ-1211, 1 sheet, scale 1:24,000. [Also available at http://ngmdb.usgs.gov/ Prodesc/proddesc_10749.htm.]

Kepferle, R.C., 1974b, Geologic map of the Louisville East quadrangle, Jefferson County, Kentucky: U.S. Geological Survey Geologic Quadrangle Map GQ-1203, 1 sheet, scale 1:24,000. [Also available at http://pubs.er.usgs.gov/publication/gq1203.]

Koerschner, W.F., III, and Read, J.F., 1989, Field and modeling studies of Cambrian carbonate cycles, Virginia Appalachians: Journal of Sedimentary Petrology, v. 59, no. 5, p. 654-687, http:// archives.datapages.com/data/sepm/journals/v59-62/ data/059/059005/0654.htm?q=\%2BtitleStrip\%3Afiel $\mathrm{d}+$ titleStrip $\% 3$ Amodeling+titleStrip \%3Astudies+titl eStrip\%3Acambrian+titleStrip \%3Acarbonate+titleSt rip $\% 3$ Acarbonate+titleStrip $\% 3$ Acycles + titleStrip $\% 3$ Avirginia+titleStrip\%3Aappalachians.

Kolata, D.R., Huff, W.D., and Bergström, S.M., 1996, Ordovician K-bentonites of eastern North America: Geological Society of America Special Paper 313, 84 p., 8 pls., http://specialpapers.gsapubs.org/content/313/1.full.pdf + html? sid=5c4fa17a-cf98-458b8 ce8-d7fee643dcd1. 
Kolata, D.R., Huff, W.D., and Bergström, S.M., 2001, The Ordovician Sebree trough; An oceanic passage to the Midcontinent United States: Geological Society of America Bulletin, v. 113, no. 8, p. 1067-1078, http://gsabulletin.gsapubs.org/content/113/8/1067. full.pdf + html? sid=ea3ef5ea-a2ae-48ff-9027a14e1481d53e.

Kolata, D.R., and Nelson, W.J., 1997, Role of the Reelfoot rift/Rough Creek graben in the evolution of the Illinois basin, in Ojakangas, R.W., Dickas, A.B., and Green, J.C., eds., Middle Proterozoic to Cambrian rifting, central North America: Boulder, Colo., Geological Society of America Special Paper 312, p. 287-298, http://specialpapers.gsapubs.org/ content/312/287.full.pdf + html? sid=ea526f66-e4164d83-a02a-4eca341c61de.

Kreisa, R.D., and Springer, D.A., 1987, Lithostratigraphy and biostratigraphy of the Martinsburg Formation in southwestern Virginia with descriptive sections, in Contributions to Virginia Geology-V: Virginia Division of Mineral Resources Publication 74, p. 33-54, https://www.dmme.virginia.gov/commerce/ProductDetails.aspx?productID $=2380$.

Kubik, W., 1993, Natural fracturing style and control on Devonian shale gas production, Pike County, Kentucky: Gas Shales Technology Review, v. 8, no. 2, p. 1-25.

Kulander, B.R., and Dean, S.L., 1986, Structure and tectonics of central and southern Appalachian Valley and Ridge and Plateau provinces, West Virginia and Virginia: American Association of Petroleum Geologists Bulletin, v. 70, no. 11, p. 1674-1684, http://archives.datapages.com/data/bulletns/1986-87/ images/pg/00700011/1650/16740.pdf.

Le Van, D.C., and Rader, E.K., 1983, Relationship of stratigraphy to occurrences of oil and gas in western Virginia: Virginia Division of Mineral Resources Publication 43, 1 sheet, https://www.
dmme.virginia.gov/commerce/ProductDetails. aspx?productID=2163.

Lidiak, E.G., Bickford, M.E., and Kisvarsany, E.B., 1993, Proterozoic geology of the eastern midcontinent region, in Reed, J.C., Jr., Bickford, M.E., Houston, R.S., Link, P.K., Rankin, D.W., Sims, P.K., and Van Schmus, W.R., eds., Precambrian; Conterminous U.S., v. C-2 of The geology of North America: Boulder, Colo., Geological Society of America, p. 259-270, http://rock.geosociety.org/Store/detail. aspx?id=DNAGGNAC2.

Lierman, R.T., Mason, C.E., Pashin, J.C., and Ettensohn, F.R., 1992, Cleveland Shale-throughlower Borden sequence (Devonian-Mississippian) and implications, in Ettensohn, F.R., ed., Changing interpretations of Kentucky geology; Layer-cake, facies, flexure, and eustacy: Ohio Geological Survey Miscellaneous Report No. 5, p. 77-81, http:/geosurvey.ohiodnr.gov/publications-maps-data/miscellaneous-items/misc-reports-mr.

Lloyd, O.B., Jr., and Reid, M.S., 1990, Evaluation and liquid waste-storage potential based on porosity distribution in the Paleozoic rocks in central and southern parts of the Appalachian basin: U.S. Geological Survey Professional Paper 1468, 81 p., 3 pls. in pocket. [Also available at http://pubs.er.usgs.gov/ publication/pp1468.]

Lucier, Amie, Zoback, Mark, Gupta, Neeraj, and Ramakrishnan, T.S., 2006, Geomechanical aspects of $\mathrm{CO}_{2}$ sequestration in a deep saline reservoir in the Ohio River Valley region: Environmental Geology, v. 13 , no. 2 , p. 85-103, http://eg.geoscienceworld. org/content/13/2/85.full.pdf + html.

Lusk, R.G., 1927, The significance of structure in the accumulation of oil in Tennessee: American Association of Petroleum Geologists Bulletin, v. 11, no. 9, p. 905-917, http://archives.datapages.com/data/bulletns/1917-30/images/pg/00110009/0900/09050.pdf.
MacQuown, W.C., Jr., 1968, Geology of the Nicholasville quadrangle, Jessamine and Fayette Counties, Kentucky: U.S. Geological Survey Geologic Quadrangle Map GQ-767, 1 sheet, scale 1:24,000. [Also available at http://pubs.er.usgs.gov/publication/ gq767.]

MacQuown, W.C., and Pear, J.L., 1983, Regional and local geologic factors control Big Lime stratigraphy and exploration for petroleum in eastern Kentucky, in Luther, M.K., ed., Proceedings of the Technical Sessions; Kentucky Oil and Gas Association, 44th Annual Meeting, June 11-13, 1980, Kentucky Geological Survey Special Publication 9, ser. 11, p. 1-20.

Markello, J.R., and Read, J.F., 1982, Upper Cambrian intrashelf basin, Nolichucky Formation, southwest Virginia Appalachians: American Association of Petroleum Geologists Bulletin, v. 66, no. 7, p. $860-878$, http://archives.datapages.com/data/bulletns/1982-83/images/pg/00660007/0850/08600.pdf.

Matchen, D.L., and Vargo, A.G., 1996, Play Mws; Mississippian Weir sandstones, in Roen, J.B., and Walker, B.J., eds., The atlas of major Appalachian gas plays: West Virginia Geological and Economic Survey Publication V-25, p. 46-50.

Maynard, J.P., Eriksson, K.A., and Law, R.D., 2006, The Upper Mississippian Bluefield Formation in the central Appalachian basin; A hierarchical sequence-stratigraphic record of a greenhouse to icehouse transition: Sedimentary Geology, v. 192, nos. 1-2, p. 99-122, http://ac.els-cdn.com/ S0037073806001126/1-s2.0-S0037073806001126main.pdf? tid=03adebe2-2fb6-11e4-89b800000aab0f26\&acdnat $=1409342132$ fcf6dca1dc97eb42e3d68281f9215c7b.

McBride, J.H., Kolata, D.R., and Hildenbrand, T.G., 2001, New constraints on interpreting the origin of the eastern granite-rhyolite province beneath the Illinois basin [abs.]: Geological Society of America 
Abstracts with Programs, v. 33, no. 6, p. A-92, https://gsa.confex.com/gsa/2001AM/finalprogram/ abstract 14748.htm.

McClay, K.R., 1992, Glossary of thrust tectonic terms, in McClay, K.R., ed., Thrust tectonics: London, United Kingdom, Chapman and Hall, p. 419-433.

McDowell, R.C., 1978, Geologic map of the Levee quadrangle, east-central Kentucky: U.S. Geological Survey Geologic Quadrangle Map GQ-1478, 1 sheet, scale 1:24,000. [Also available at http://pubs. er.usgs.gov/publication/gq1478.]

McDowell, R.C., 1983, Stratigraphy of the Silurian outcrop belt on the east side of the Cincinnati arch in Kentucky, with revisions in the nomenclature: U.S. Geological Survey Professional Paper 1151-F, 27 p., 2 pls. in pocket. [Also available at http://pubs. er.usgs.gov/publication/pp1151F.]

McDowell, R.C., Grabowski, G.J., Jr., and Moore, S.L., 1981, Geologic map of Kentucky: U.S. Geological Survey in cooperation with the Kentucky Geological Survey, 4 sheets, scale 1:250,000.

McGuire, W.H., and Howell, Paul, 1963, Oil and gas possibilities of the Cambrian and Lower Ordovician in Kentucky: Lexington, Kentucky, Spindletop Research Center, 216 p., http://kgs.uky.edu/kgsweb/ pubs/pubsearch.asp.

Meglen, J.F., and Noger, M.C., 1996, Play DSu; Lower Devonian-Upper Silurian unconformity play, in Roen, J.B., and Walker, B.J., eds., The atlas of major Appalachian gas plays: West Virginia Geological and Economic Survey Publication V-25, p. 133-138, http:/www.wvgs.wvnet.edu/wvges2/publications/ PubCat_Details.aspx?PubCatID=V-25.

Meissner, C.R., Jr., 1978, Geologic map of the Duty quadrangle, Dickenson, Russell, and Buchanan Counties, Virginia: U.S. Geological Survey Geologic
Quadrangle Map GQ-1458, 1 sheet, scale 1:24,000. [Also available at http://pubs.er.usgs.gov/publication/ gq1458.]

Milici, R.C., 1980, Relationship of regional structure to oil and gas producing area in the Appalachian basin: U.S. Geological Survey Miscellaneous Investigation Map I-917-F, 5 sheets, scale 1:2,500,000. [Also available at http://pubs.er.usgs.gov/publication/ i917F.]

Milici, R.C., and de Witt, Wallace, Jr., 1988, The Appalachian basin, in Sloss, L.L., ed., Sedimentary cover-North American craton, U.S., v. D-2 of The geology of North America: Boulder, Colo., Geological Society of America, p. 427-469, http://rock. geosociety.org/Store/detail.aspx?id=DNAGGNAD2 .

Milici, R.C., Ryder, R.T., Swezey, C.S., Charpentier, R.R., Cook, T.A., Crovelli, R.A., Klett, T.R., Pollastro, R.M., and Schenk, C.J., 2003, Assessment of undiscovered oil and gas resources of the Appalachian basin province, 2002: U.S. Geological Survey Fact Sheet FS-009-03, 2 p. [Also available at http:// pubs.er.usgs.gov/publication/fs00903.]

Miller, D.J., and Eriksson, K.A., 2000, Sequence stratigraphy of Upper Mississippian strata in the central Appalachians; A record of glacioeustasy and tectonoeustacy in a foreland basin setting: American Association of Petroleum Geology Bulletin, v. 84, no. 2, p. 210-233, http://archives.datapages.com/ data/bulletns/2000/02feb/0210/images/00_0210.pdf.

Miller, M.S., 1974, Stratigraphy and coal beds of Upper Mississippian and Lower Pennsylvanian rocks in southwestern Virginia: Virginia Division of Mineral Resources Bulletin 84, 211 p., 7 pls., https:// www.dmme.virginia.gov/commerce/ProductDetails. aspx?productID=2193.

Miller, R.L., and Meissner, C.R., Jr., 1977, Geologic map of the Big A Mountain quadrangle, Buchanan and Russell Counties, Virginia: U.S. Geological Survey Geologic Quadrangle Map GQ-1350, 1 sheet, scale 1:24,000. [Also available at http://pubs.er.usgs. gov/publication/gq1350.]

Miller, R.L., Back, William, and Deike, R.G., 1977, Wildcat Valley Sandstone in southwest VirginiaPossible reservoir sandstone: American Association of Petroleum Geologists Bulletin, v. 61, no. 3, p. 416-430, http://archives.datapages.com/data/bulletns/1977-79/images/pg/00610003/0400/04160.pdf.

Mitchell, C.E., and Bergstrom, S.M., 1991, New graptolite and lithostratigraphic evidence from the Cincinnati region, U.S.A., for the definition and correlation of the base of the Cincinnatian Series (Upper Ordovician), in Barnes, C.R., and Williams, S.H., eds., Advances in Ordovician geology: Geological Survey of Canada Paper 90-9, p. 59-77, http://ftp2. cits.rncan.gc.ca/pub/geott/ess_pubs/132/132172/ pa_90_09.pdf.

Mitchell, M.L., 1982, Stratigraphic cross section $D-D$, in Mitchell, M.L., Morris, M.S., Polzin, J.K., Nolde, J.E., and Grantham, J.H., Stratigraphic cross sections for the Upper Mississippian-Middle Pennsylvanian units of Buchanan and Dickenson Counties, southwest Virginia: Virginia Division of Mineral Resources Publication 42, 3 p., 4 pls., https://www. dmme.virginia.gov/commerce/ProductDetails. aspx?productID=2648.

Mitchell, M.L., Morris, M.S., Grantham, J.H., and Nolde, J.E., 1984, Geologic map of the Prater and Vansant quadrangles, Virginia: Virginia Division of Mineral Resources Publication 52, 1 sheet, scale 1:24,000, https://www.dmme.virginia.gov/commerce/ProductDetails.aspx? productID=2334.

Mitra, Shankar, 1988, Three-dimensional geometry and kinematic evolution of the Pine Mountain thrust system, southern Appalachians: Geological Society of America Bulletin, v. 100, no. 1, p. 72-95, 
http://gsabulletin.gsapubs.org/content/100/1/72. full.pdf + html? sid=936af6d3-1d6f-40d2-8bdc8cb5b94a927c.

Mussman, W.J., Montanez, I.P., and Read, J.F., 1988, Ordovician Knox paleokarst unconformity, Appalachians, in James, N.P. and Choquette, P.W., eds., Paleokarst: New York, Springer-Verlag, p. 211-228.

Noger, M.C., 1988, comp., 1988, Geologic map of Kentucky; Sesquicentennial edition of the Kentucky Geological Survey: Reston, Virginia, U.S. Geological Survey, 1 sheet, scale 1:500,000, http://kgs.uky.edu/ kgsweb/olops/pub/kgs/500Kgeomap1.pdf. [Compiled from McDowell, R.C., Grabowski, G.J., Jr., and Moore, S.L., 1981, Geologic map of Kentucky: Reston, Virginia, U.S. Geological Survey, 4 sheets, scale $1: 250,000$.]

Noger, M.C., Meglen, J.F., Humphreys, Matthew, and Baranoski, M.T., 1996, Play Sld; Upper Silurian Lockport Dolomite-Keefer (Big Six) Sandstone, in Roen, J.B., and Walker, B.J., eds., The atlas of major Appalachian gas plays: West Virginia Geological and Economic Survey Publication V-25, p. 145-150, http://www.wvgs.wvnet.edu/wvges2/publications/ PubCat_Details.aspx?PubCatID=V-25.

Noger, M.C., and Drahovzal, J.A., 2005, Lithostratigraphy of Precambrian and Paleozoic rocks along structural cross section KY-1, Crittenden County to Lincoln County, Kentucky: Kentucky Geological Survey Report of Investigations 13, ser. 12, 29 p., 1 pl., http://kgs.uky.edu/kgsweb/olops/pub/ kgs/RI13_12.pdf.

Nolde, J.E., 1994, Devonian to Pennsylvanian stratigraphy and coal beds of the Appalachian plateaus province, in Geology and mineral resources of the southwest Virginia coalfield: Virginia Division of Mineral Resources Publication 131, p. 1-85, https:// www.dmme.virginia.gov/commerce/ProductDetails. aspx? productID=2199.
Opritza, S.T., 1996, Play Dop; Lower Devonian Oriskany Sandstone updip permeability pinchout, in Roen, J.B., and Walker, B.J., eds., The atlas of major Appalachian gas plays: West Virginia Geological and Economic Survey Publication V-25, p. 126-129, http://www.wvgs.wvnet.edu/wvges2/publications/ PubCat_Details.aspx?PubCatID=V-25.

Osberg, P.H., Tull, J.F., Robinson, Peter, Hon, Rudolph, and Butler, J.R., 1989, The Acadian orogen, in Hatcher, R.D., Jr., Thomas, W.A., and Viele, G.W., eds., The Appalachian-Ouachita orogen in the United States, v. F-2 of The geology of North America: Boulder, Colo., Geological Society of America, p. 179-232, http://rock.geosociety.org/Store/detail. aspx?id=DNAGGNAF2.

Outerbridge, W.F., 1968, Geologic map of the David quadrangle, eastern Kentucky: U.S. Geological Survey Geologic Quadrangle Map GQ-720, 1 sheet, scale 1:24,000. [Also available at http://pubs.er.usgs. gov/publication/gq720.]

Palmer, A.R., 1971, The Cambrian of the Appalachians and eastern New England region, in Holland, C.H., ed., The Cambrian of the New World: London, United Kingdom, Wiley-Interscience, p. 169-217.

Pashin, J.C., and Ettensohn, F.R., 1995, Reevaluation of the Bedford-Berea sequence in Ohio and adjacent States; Forced regression in a foreland basin: Geological Society of America Special Paper 298, 68 p., http://specialpapers.gsapubs.org/content/298/1. full.pdf + html? sid=bbbc54d2-9585-463d-a0755a93bba08001.

Patchen, D.G., Avary, K.L., and Erwin, R.B., coordinators, 1985, Correlation of stratigraphic units in North America, northern Appalachian region correlation chart: Tulsa, Okla., American Association of Petroleum Geologists, 1 sheet.
Pavlides, Louis, Boucot, A.J., and Skidmore, W.B., 1968, Stratigraphic evidence for the Taconic orogeny in the northern Appalachians, in Zen, E-an., White, W.S., Hadley, J.B., and Thompson, J.B., Jr., eds., Studies of Appalachian geology; Northern and maritime: New York, Wiley Interscience Publishers, p. 61-82.

Pavlides, Louis, 1989, Early Paleozoic composite mélange terrane, central Appalachian Piedmont, Virginia and Maryland; Its origin and tectonic history, in Horton, J.W., Jr., and Rast, N.Z., eds., Mélanges olistostromes of the U.S. Appalachians: Geological Society of America Special Paper 228, p. 135-194, http://specialpapers.gsapubs.org/content/228/135. full.pdf + html? sid=3dae3a1d-d8a9-4b15-94c2$69 \mathrm{~b} 7930 \mathrm{c} 8 \mathrm{~d} 03$.

Perry, W.J., Jr., 1972, The Trenton Group of Nittany anticlinorium, eastern West Virginia: West Virginia Geological and Economic Survey Circular 13, 30 p., http://www.wvgs.wvnet.edu/wvges2/publications/ PubCat_DetailSearch.aspx.

Pope, M.C., and Read, J.F., 1997, High-resolution surface and subsurface sequence stratigraphy of late Middle to Late Ordovician (late Mohawkian-Cincinnatian) foreland basin rocks, Kentucky and Virginia: American Association of Petroleum Geologists Bulletin, v. 81, no. 11, p. 1866-1893, http://archives. datapages.com/data/bulletns/1997/11nov/1866/ Images/97_1866.PDF.

Price, M.L., 1981, A regional study of the St. Peter Sandstone in eastern Kentucky, in Luther, M.K., ed., Proceedings of the Technical Sessions; Kentucky Oil and Gas Association, 38th Annual Meeting, June 6-7, 1974: Kentucky Geological Survey Special Publication 3, ser. 11, p. 1-19.

Quinlan, G.M., and Beaumont, Christopher, 1984, Appalachian thrusting, lithospheric flexure, and the Paleozoic stratigraphy of the eastern interior of North 
America: Canadian Journal of Earth Science, v. 21 no. 9, p. 973-996, http://www.nrcresearchpress.com/ doi/pdf/10.1139/e84-103.

Rankin, D.W., Drake, A.A., Jr., Glover, Lynn, III, Goldsmith, Richard, Hall, L.M., Murray, D.P., Ratcliffe, N.M., Read, J.F., Secor, D.T., Jr., and Stanley, R.S., 1989, Pre-orogenic terranes, in Hatcher, R.D., Thomas, W.A., and Viele, G.W., eds., The Appalachian-Ouachita orogen in the United States, v. F-2 of The geology of North America: Boulder, Colo., Geological Society of America, p. 7-99, http://rock. geosociety.org/Store/detail.aspx?id=DNAGGNAF2.

Rankin, D.W., Chiarenzelli, J.R., Drake, A.A., Jr., Goldsmith, Richard, Hall, L.M., Hinze, W.J., Isachsen, Y.W., Lidiak, E.G., McLelland, James, Mosher, Sharon, Ratcliffe, N.M., Secor, D.T., and Whitney, P.R., 1993, Proterozoic rocks east and southeast of the Grenville front, in Reed, J.C., Jr., Bickford, M.E., Houston, R.S., Link, P.K., Rankin, D.W., Sims, P.K., and Van Schmus, W.R., eds., Precambrian; Conterminous U.S., v. C-2 of The geology of North America: Boulder, Colo., Geological Society of America, p. 335-461, http://rock.geosociety. org/Store/detail.aspx?id=DNAGGNAC2.

Rankin, D.W., Dillon, W.P., Black, D.F.B., Boyer, S.E., Daniels, D.L., Goldsmith, R., Grow, J.A., Horton, J.W., Jr., Hutchinson, D.R., Klitgord, K.D., McDowell, R.C., Milton, D.J., Owens, J.P., and Phillips, J.D., 1991, Continent-ocean transect E-4; Central Kentucky to Carolina trough: Geological Society of America Centennial Continent-Ocean Transect 16, 41 p., 2 sheets, scale 1:500,000.

Read, J.F., 1980, Carbonate ramp-to-basin transitions and foreland basin evolution, Middle Ordovician, Virginia Appalachians: American Association of Petroleum Geologists Bulletin, v. 64, no. 10, p. 1575-1612, http://archives.datapages.com/data/ bulletns/1980-81/images/pg/00640010/1550/15750. pdf.
Read, J.F., 1989a, Evolution of Cambro-Ordovician passive margin, U.S. Appalachians, in Rankin, D.W., Drake, A.A., Jr., Glover, Lynn, III, Goldsmith, Richard, Hall, L.M., Murray, D.P., Ratcliffe, N.M., Read, J.F., Secor, D.T., Jr., and Stanley, R.S., Pre-orogenic terranes, in Hatcher, R.D., Jr., Thomas, W.A., and Viele, G.W., eds., The Appalachian-Ouachita orogen in the United States, v. F-2 of The geology of North America: Boulder, Colo., Geological Society of

America, p. 42-57, http://rock.geosociety.org/Store/ detail.aspx?id=DNAGGNAF2.

Read, J.F., 1989b, Controls on evolution of CambrianOrdovician passive margin, U.S. Appalachians, in Crevello, P.D., Wilson, J.L., Sarg, J.F., and Read, J.F., eds., Controls on carbonate platform and basin development: Society for Economic Paleontologists and Mineralogists Special Publication 44, p. 147-165, http://archives.datapages.com/data/ sepm_sp/SP44/Controls_on_Evolution_of_Cambrian-Ordovician.pdf.

Renfro, H.B, and Feray, D.E., comps., 1970, Geological highway map of the Mid-Atlantic region; Kentucky, West Virginia, Maryland, North Carolina, Tennessee, Virginia, Delaware, South Carolina: American Association of Petroleum Geologists United States Geological Highway Map Series, Map 4, 1 sheet, scale $1: 1,875,000$.

Repetski, J.E., 1985, Conodont biostratigraphy of the Knox Group at the Thorn Hill and River Ridge sections, northeastern Tennessee, in Walker, K.R., ed., The geologic history of the Thorn Hill Paleozoic section (Cambrian-Mississippian), eastern Tennessee: University of Tennessee Department of Geological Sciences Studies in Geology 10, p. 25-31.

Rice, C.L., 1985, Terrestrial vs. marine depositional model-A new assessment of subsurface Lower Pennsylvanian rocks of southwestern Virginia: Geology, v. 13, no. 11, p. 786-789, http://geology.geoscienceworld.org/content/13/11/786.full.pdf+html.
Rice, C.L., and Schwietering, J.F., 1988, Fluvial deposition in the central Appalachians during the Early Pennsylvanian: U.S. Geological Survey Bulletin 1839-B, p. B1-B10. [Also available at http://pubs. er.usgs.gov/publication/b1839AD.]

Richard, B.H., Wolfe, P.J., and Potter, P.E., 1997, PreMount Simon basins of western Ohio, in Ojakangas, R.W., Dickas, A.B., and Green, J.C., eds., Middle Proterozoic to Cambrian rifting, central North America: Geological Society of America Special Paper 312, p. 243-252, http://specialpapers.gsapubs. org/content/312/243.full.pdf + html? sid $=57 \mathrm{~b} 3 \mathrm{~d} 96 \mathrm{e}-$ f0a2-4361-bc3b-f30077823893.

Richardson, J.G., and Bergstrom, S.M., 2003, Regional stratigraphic relations of the Trenton Limestone (Chatfieldian, Ordovician) in the eastern North American midcontinent: Northeastern Geology and Environmental Sciences, v. 18, no. 2, p. 93-115.

Riley, R.A., Harper, J.A., Baranoski, M.T., Laughrey, C.D., and Carlton, R.W., 1993, Measuring and predicting reservoir heterogeneity in complex depocenters; The Late Cambrian Rose Run Sandstone of eastern Ohio and western Pennsylvania: U.S. Department of Energy, contract no. DE-AC22-90BC14657, 259 p.

Riley, R.A., Baranoski, M.T., and Wickstrom, L.H., 2006, Regional stratigraphy of the Trenton-Black River, in Patchen, D.G., Hickman, J.B., Harris, D.C., Drahovzal, J.A., Lake, P.D., Smith, L.B., Nyahay, R., Schulze, R., Riley, R.A., Baranoski, M.T., Wickstrom, L.H., Laughrey, C.D., Kostelnik, J., Harper, J.A., Avary, K.L., Bocan, J., Hohn, M.Ed., and McDowell, R., A geologic play book for Trenton-Black River Appalachian basin exploration: U.S. Department of Energy, award no. DE-FC2603NT41856, p. 4-38, 30 pls.

Roden-Tice, M.K., and Shrake, D.L., 1998, Age of the Middle Run Sandstone underlying Warren County, 
Ohio [abs]: Geological Society of America Abstracts with Programs, v. 30, no. 2, p. 69.

Rodgers, John, 1953, Geologic map of east Tennessee with explanatory text: Tennessee Division of Geology Bulletin 58, pt. 2, 168 p., 15 pls.

Rodgers, John, 1963, Mechanics of Appalachian foreland folding in Pennsylvania and West Virginia: American Association of Petroleum Geologists Bulletin, v. 47, no. 8, p. 1527-1536, http://archives. datapages.com/data/bulletns/1961-64/images/ pg/00470008/1500/15270.pdf.

Rodgers, John, 1970, The tectonics of the Appalachians: New York, Wiley Interscience, $271 \mathrm{p}$.

Rodgers, John, 1988, Fourth time-slice; Mid-Devonian to Permian synthesis, in Harris, A.L., and Fettes, D.J., eds., The Caledonian-Appalachian orogen: Geological Society of London Special Publication 38, p. $621-626$.

Roen, J.B., 1984, Geology of the Devonian black shales of the Appalachian basin: Organic Geochemistry, v. 5, no. 4, p. 241-254, http://marcelluscenter.psu.edu/ seminars-conferences/earthtalks-spring2009-marcellus-supplements/Roen84BlkShDevorggeoch.pdf.

Roen, J.B., and Kepferle, R.C., eds., 1993, Petroleum geology of the Devonian and Mississippian black shale of eastern North America: U.S. Geological Survey Bulletin 1909-A-N, separately paginated. [Also available at http://pubs.er.usgs.gov/publication/ b1909.]

Ryder, R.T., 2006, Stratigraphic framework and depositional sequences in the Lower Silurian regional oil and gas accumulation, Appalachian basin; From Licking County, Ohio, to Fayette County, West Virginia: U.S. Geological Survey Scientific Investigations Map 2916, 2 sheets. [Also available at http:// pubs.usgs.gov/sim/2006/2916/.]
Ryder, R.T., Crangle, R.D., Jr., Trippi, M.H., Swezey, C.S., Lentz, E.E., Rowan, E.L., and Hope, R.S., 2009, Geologic cross section $D-D$ ' through the Appalachian basin from the Findlay arch, Sandusky County, Ohio, to the Valley and Ridge province,

Hardy County, West Virginia: U.S. Geological Survey Scientific Investigations Map 3067, 2 sheets, 52-p. text. [Also available at http://pubs.usgs.gov/ $\operatorname{sim} / 3067 /$.

Ryder, R.T., Crangle, R.D., Jr., Repetski, J.E., and Harris, A.G., 2008, Stratigraphic framework of Cambrian and Ordovician rocks in the Appalachian basin from Sequatchie County, Tennessee, through eastern Kentucky, to Mingo County, West Virginia: U.S. Geological Survey Scientific Investigations Map 2994, 1 pl. [Also available at http://pubs.usgs. gov/sim/2994/.]

Ryder, R.T., Repetski, J.E., and Harris, A.G., 1997, Stratigraphic framework of Cambrian and Ordovician rocks in the central Appalachian basin from Campbell County, Kentucky, to Tazewell County, Virginia [section $G-G$ ']: U.S. Geological Survey Miscellaneous Investigations Series Map I-2530, 1 sheet. [Superseded in 2004 by version 2.0, revised and digitized by E.E. Lentz, http://pubs.usgs.gov/ imap/i-2530/.]

Ryder, R.T., Swezey, C.S., Crangle, R.D., Jr., and Trippi, M.H., 2008, Geologic cross section $E-E$, through the Appalachian basin from the Findlay arch, Wood County, Ohio, to the Valley and Ridge province, Pendleton County, West Virginia: U.S. Geological Survey Scientific Investigations Map 2985, 2 sheets, 48-p. text. [Also available at http:// pubs.usgs.gov/sim/2985/.]

Ryder, R.T., Trippi, M.H., Swezey, C.S., Crangle, R.D., Jr., Hope, R.S., Rowan, E.L., and Lentz, E.E., 2012, Geologic cross section $C-C$ ' through the Appalachian basin from Erie County, north-central Ohio, to the Valley and Ridge province, Bedford County, south-central Pennsylvania: U.S. Geological Survey Scientific Investigations Map 3172, 2 sheets, 70-p. text. [Also available at http://pubs.usgs.gov/ $\operatorname{sim} / 3172 /$.

Sable, E.G., 1978, Geologic map of the Cannel City quadrangle, eastern Kentucky: U.S. Geological Survey Geologic Quadrangle Map GQ-1498, 1 sheet, scale $1: 24,000$. [Also available at http://pubs.usgs. gov/gq/1498/report.pdf.]

Sable, E.G., and Dever, G.R., Jr., 1990, Mississippian rocks in Kentucky: U.S. Geological Survey Professional Paper 1503, 125 p., 1 pl. in pocket. [Also available at http://pubs.usgs.gov/pp/1503/report.pdf.]

Santos, J.O.S., Hartmann, L.A., McNaughton, N.J., Easton, R.M., Rea, R.G., and Potter, P.E., 2002, Sensitive high resolution ion microprobe (SHRIMP) detrital zircon geochronology provides new evidence for a hidden Neoproterozoic foreland basin to the Grenville orogen in the eastern Midwest, U.S.A.: Canadian Journal of Earth Sciences, v. 39, no. 10, p. 1505-1515, http://www.nrcresearchpress.com/doi/ pdf/10.1139/e02-052.

Schultz, A.P., 1988, Horses in fensters of the Pulaski thrust sheet, southwestern Virginia; Structure, kinematics, and implications for hydrocarbon potential of the Eastern Overthrust Belt: Chapter A, in U.S. Geological Survey Bulletin 1839, p. A1-A13. [Also available at http://pubs.er.usgs.gov/publication/ b1839AD.]

Schwab, F.L., 1986, Upper Precambrian-lower Paleozoic clastic sequences, Blue Ridge and adjacent areas, Virginia and North Carolina; Initial rifting and continental margin development, Appalachian orogen, Field trip 1 of Textoris, D.A., ed., Society of Economic Paleontologists and Mineralogists (SEPM) Third Annual Midyear Meeting, Southeastern 
U.S.A., 1986, Raleigh, N.C., Field trip guidebook: Tulsa, Okla., Society of Economic Paleontologists and Mineralogists, p. 1-42.

Schwalb, Howard, and Norris, Ronald, 1980, Structure map on the base of the New Albany Shale in western Kentucky: U.S. Department of Energy [DOE] Morgantown Energy Technology Center, Eastern Gas Shale Project Series No. 907, 1 sheet. [Prepared under contract number EW-78-S-21-8215.]

Seeger, C.R., Asaro, Frank, Michel, Helen, Alvarez, Walter, and Alvarez, Luiz, 1985, Iridium discovery at Jeptha Knob cryptoexplosion structure, Kentucky [abs.], in Bowman, L., Dotson, R., Hrametz, K., and McCasey, T., comps., Abstracts of papers submitted to the Sixteenth Lunar and Planetary Science Conference, Houston, Tex., 1985: Houston, Tex., Lunar and Planetary Science Conference, v. 16, pt. 2, p. 757-758, http://www.lpi.usra.edu/meetings/ lpsc1985/pdf/1386.pdf.

Shell, J.A., Jones, S.E., and Dennison, J.M., 1984, Lower Devonian of southwestern Virginia, in Shumaker, R.C., comp., Sixth Appalachian Basin Industrial Associates Program, Spring Meeting; Columbus, Ohio, March 22-23, 1984: Morgantown, West Virginia, Appalachian Basin Industrial Associates, v. 6, p. 76-97.

Shrake, D.L., Carlton, R.W., Wickstrom, L.H., Potter, P.E., Richard, B.H., Wolfe, P.J., and Sitler, G.W., 1991, Pre-Mount Simon basin under the Cincinnati arch: Geology, v. 19, no. 2, p. 139-142, http:// geology.geoscienceworld.org/content/19/2/139. full.pdf + html?sid=975c2680-20c5-440f-b096$18 \mathrm{e} 389$ deddc 5 .

Shrake, D.L., Wolfe, P.J., Richard, B.H., Swinford, E.M., Wickstrom, L.H., Potter, P.E., and Sitler, G.W., 1990, Lithologic and geophysical description of a continuously cored hole in Warren County, Ohio, including description of the Middle Run Formation (Precambrian?) and a seismic profile across the core site: Ohio Division of Geological Survey Information Circular No. 56, 11 p., 2 pls.

Shumaker, R.C., 1978, Porous fracture facies in Devonian shales of eastern Kentucky and West Virginia, in Wheeler, R.L., and Dean, C.S., eds., Preprints for Second Eastern Gas Shales Symposium, Morgantown, West Virginia, October, 1978: Morgantown, West Virginia, U.S. Department of Energy Morgantown Energy Technology Center, v. 1, no. METC/SP-78/6, p. 360-369, http://www.netl.doe. gov/KMD/Cds/disk7/disk1/EGS $\% 5$ CPreprints $\% 20$ for $\% 20$ Second $\% 20$ Eastern $\% 20$ Gas $\% 20$ Shale $\% 20$ Symposium $\% 20$ Vol\%20I\%20\&\%20Vol.pdf.

Shumaker, R.C., 1996, Structural history of the Appalachian basin, in Roen, J.B., and Walker, B.J., eds., The atlas of major Appalachian gas plays: West Virginia Geological and Economic Survey Publication V-25, p. 8-22, http://www.wvgs.wvnet.edu/wvges2/publications/PubCat_Details.aspx?PubCatID=V-25.

Shumaker, R.C., and Wilson, T.H., 1996, Basement structure of the Appalachian foreland in West Virginia; Its style and effect on sedimentation, in van der Pluijm, B.A., and Catacosinos, P.A., eds., Basement and basins of eastern North America: Geological Society of America Special Paper 308, p. 139-155, http://specialpapers.gsapubs.org/content/308/139.full.pdf + html? sid $=\mathrm{c0a06300-02b4-}$ 4416-9465-5275b803ef88.

Simpson, E.L., and Eriksson, K.A., 1990, Early Cambrian progradational and transgressive sedimentation patterns in Virginia; An example of the early history of a passive margin: Journal of Sedimentary Petrology, v. 60, no. 1, p. 84-100, http:// archives.datapages.com/data/sepm/journals/v59-62/ data/060/060001/pdfs/0084.pdf.
Sloss, L.L., 1963, Sequences in the cratonic interior of North America: Geological Society of America Bulletin, v. 74, no. 2, p. 93-114.

Sloss, L.L., 1988, Tectonic evolution of the craton in Phanerozoic time, in Sloss, L.L., ed., Sedimentary cover-North American craton, v. D-2 of The geology of North America: Boulder, Colo., Geological Society of America, p. 25-51, http://rock.geosociety. org/Store/detail.aspx?id=DNAGGNAD2.

Slucher, E.R., Swinford, E.M., Larsen, G.E., Schumacher, G.A., Shrake, D.L., Rice, C.L., Caudill, M.R., Rea, R.G., and Powers, D.M., comps., 2006, Bedrock geologic map of Ohio: Ohio Division of Geological Survey Map BG-1, 1 sheet, scale 1:500,000.

Smith, L.A., Gupta, N., Sass, B.M., Bubenik, T.A., Byrer, C., and Bergman, P., 2002, Engineering and economic assessment of carbon dioxide sequestration in saline formations: Journal of Energy and Environmental Research, v. 2, no. 1, p. 5-22, http://www. netl.doe.gov/File\%20Library/Publications/Journals/ vol2 no1.pdf.

Smosna, R.A., 1983, Depositional patterns of a Silurian shelf sand in the central Appalachians: Northeastern Geology, v. 5, no. 2, p. 100-109.

Smosna, Richard, 1988, Paleogeographic reconstruction of the Lower Devonian Helderberg Group in the Appalachian basin, in McMillan, N.J., Embry, A.F., and Glass, D.J., eds., Regional synthesis, v. 1 of Devonian of the world-Proceedings of the Second International Symposium on the Devonian System [Calgary, Alberta, Canada]: Calgary, Alberta, Canada, Canadian Society of Petroleum Geologists, p. 265-275, http://archives.datapages.com/data/ cspg_sp/data/014/014001/pdfs/265.pdf.

Smosna, Richard, Conrad, J.M., and Maxwell, T., 1989, Stratigraphic traps in Silurian Lockport Dolomite of Kentucky: American Association of Petroleum 
Geologists Bulletin, v. 73, no. 7, p. 874-886, http:// archives.datapages.com/data/bulletns/1988-89/ images/pg/00730007/0850/08740.pdf.

Smosna, R.A., Patchen, D.G., Warshauer, S.M., and Perry, W.J., Jr., 1977, Relationships between depositional environments, Tonoloway Limestone, and distribution of evaporites in the Salina Formation, West Virginia, in Fisher, J.H., ed., Reefs and evaporites - Concepts and depositional models: American Association of Petroleum Geologists Studies in Geology 5, p. 125-143, http://archives. datapages.com/data/specpubs/carbona1/images/a046/ a0460001/0100/01250.pdf.

Smosna, Richard, and Patchen, Douglas, 1978, Silurian evolution of central Appalachian basin: American Association of Petroleum Geologists Bulletin, v. 62, no. 11, p. 2308-2328, http://archives. datapages.com/data/bulletns/1977-79/images/ pg/00620011/2300/23080.pdf.

Souder, W.J., and Zafar, J.S., 1977, Partial sample description of VDMR well no. 951: Virginia Department of Mines Well Sample Description Report, 5 p.

Stamm, Rob, 2004, Stop 6. Loyalhanna Limestone Member of the Mauch Chunk Formation at the Keystone quarry, Springs, Pennsylvania, in Southworth, Scott, and Burton, William, eds., Geology of the National Capital region-Field trip guidebook: U.S. Geological Survey Circular 1264, p. 98-101. [Also available at http://pubs.usgs.gov/circ/2004/1264/ report.pdf.]

Stark, T.J., 1997a, The English graben; A possible Precambrian rift segment of the eastern Midcontinent, in Ojakangas, R.W., Dickas, A.B., and Green, J.C., eds., Middle Proterozoic to Cambrian rifting, central North America: Geological Society of America Special Paper 312, p. 267-285, http://specialpapers.gsapubs.org/content/312/253. full.pdf + html? sid=9e69bc24-3873-4adb-937c$921 \mathrm{db} 7 \mathrm{c} 4 \mathrm{~b} 865$.

Stark, T.J., 1997b, The East Continent Rift complex; Evidence and conclusions, in Ojakangas, R.W., Dickas, A.B., and Green, J.C., eds., Middle Proterozoic to Cambrian rifting, central North America: Geological Society of America Special Paper 312, p. 253-266, http://specialpapers.gsapubs.org/content/312/253.full.pdf + html? sid=9e69bc24-38734adb-937c-921db7c4b865.

Sutton, E.M., 1981, Deep exploration in eastern Kentucky by the SCLAW group during the early seventies, in Luther, M.K., ed., Proceedings of the Technical Sessions; Kentucky Oil and Gas Association, 38th Annual Meeting, June 6-7, 1974, Kentucky Geological Survey Special Publication 3, ser. 11, p. 31-44.

Sweet, W.C., 1979, Conodonts and conodont biostratigraphy of post-Tyrone Ordovician rocks of the Cincinnati region, in Pojeta, John, Jr., ed., Contribution to the Ordovician paleontology of Kentucky and nearby States: U.S. Geological Survey Professional Paper 1066-A-G, p. G1-G26. [Also available at http:// pubs.er.usgs.gov/publication/pp1066AG.]

Sweet, W.C., 1984, Graphic correlation of upper Middle and Upper Ordovician rocks, North American Midcontinent province, U.S.A., in Bruton, D.L., ed., Aspects of the Ordovician System: Paleontological Contributions from the University of Oslo [Norway], No. 295, p. 23-36.

Swezey, C.S., 2002, Regional stratigraphy and petroleum systems of the Appalachian basin, North America: U.S. Geological Survey Scientific Investigations Map 2768, 1 sheet. [Also available at http:// pubs.er.usgs.gov/publication/i2768.]
Swezey, C.S., 2009, Regional stratigraphy and petroleum systems of the Illinois basin, U.S.A.: U.S. Geological Survey Scientific Investigations Map 3068, 1 sheet. [Also available at http://pubs.usgs. gov/sim/3068/.]

Thomas, W.A., 1991, The Appalachian-Ouachita rifted margin of southeastern North America: Geological Society of America Bulletin, v. 103, no. 3, p. 415-431, http://gsabulletin.gsapubs.org/ content/103/3/415.full.pdf + html? sid $=$ c3f51d7c-282f4210-9a88-3710fff6c 737 .

Tomastik, T.E., 1997, The sedimentology of the Bass Islands and Salina Groups in Ohio and its effect on salt-solution mining and underground storage, USA: Carbonates and Evaporites,

v. 12, no. 2, p. 236-253, http://link.springer.com/ article/10.1007\%2FBF03175420\#.

Van Schmus, W.R., Bickford, M.E., and Turek, A., 1996, Proterozoic geology of the east-central Midcontinent basement, in van der Pluijm, B.A. and Catacosinos, P.A., eds., Basement and basins of eastern North America: Geological Society of America Special Paper 308, p. 7-32, http://specialpapers. gsapubs.org/content/308/7.full.pdf+html.

Vargo, A.G., and Matchen, D.L., 1996, Play Mbi; Lower Mississippian Big Injun sandstones, in Roen, J.B., and Walker, B.J., eds., The atlas of major Appalachian gas plays: West Virginia Geological and Economic Survey Publication V-25, p. 41-45.

Ver Straeten, C.A., and Brett, C.E., 2006, Pragian to Eifelian strata (middle Lower to lower Middle Devonian), northern Appalachian basin; Stratigraphic nomenclatural changes: Northeastern Geology and Environmental Sciences, v. 28, no. 1, p. 80-95.

Virginia Division of Mineral Resources, 1993, Geologic map of Virginia and expanded explanation: 
Charlottesville, Virginia, Virginia Division of Mineral Resources, 1 sheet, scale 1:500,000 and 80-p. booklet, https://www.dmme.virginia.gov/commerce/ ProductDetails.aspx?productID=1280.

Wallace, L.G., and de Witt, Wallace, Jr., 1975, Maps showing selected deep wells drilled for oil and gas in the Appalachian basin: U.S. Geological Survey Miscellaneous Investigations Series Map I-936, 3 sheets, scale 1:1,000,000. [Also available at $\mathrm{http}: / /$ pubs.er.usgs.gov/publication/i936.]

Webb, E.J., 1980, Cambrian sedimentation and structural evolution of the Rome trough in Kentucky: Cincinnati, Ohio, University of Cincinnati, Ph.D. dissertation, $98 \mathrm{p}$.

Webby, B.D., 1995, Towards an Ordovician time scale, in Cooper, J.D., Droser, M.L., and Finney, S.C., eds., Ordovician odyssey; Short papers for the Seventh International Symposium on the Ordovician System, Las Vegas, Nev., June, 1995: Los Angeles, Calif., Society of Economic Paleontologists and Mineralogists, v. 77, p. 5-9, http://archives.datapages.com/ data/pac_sepm/094/094001/pdfs/5.pdf.

Weir, G.W., and Richards, P.W., 1974, Geologic map of the Pomeroyton quadrangle, east-central Kentucky: U.S. Geological Survey Geologic Quadrangle Map GQ-1184, 1 sheet, scale 1:24,000. [Also available at http://pubs.usgs.gov/gq/1184/report.pdf.]

Weir, G.W., Peterson, W.L., Swadley, W.C., and Pojeta, John, Jr., 1984, Lithostratigraphy of Upper Ordovician strata exposed in Kentucky: U.S. Geological Survey Professional Paper 1151-E, 121 p., 5 pls. in pocket. [Also available at http://pubs.usgs.gov/ pp/1151e/report.pdf.]

Wheeler, H.E., 1963, Post-Sauk and pre-Absaroka Paleozoic stratigraphic patterns in North America: American Association of Petroleum Geologists
Bulletin, v. 47, no. 8, p. 1497-1526, http://archives. datapages.com/data/bulletns/1961-64/images/ pg/00470008/1450/14970.pdf.

Willoughby, R.H., 1976, Lower and Middle Cambrian fossils from the Shady Formation, Austinville, Virginia [abs.]: Geological Society of America Abstracts with Programs, v. 8, no. 2, p. 301-302.

Willoughby, R.H., 1977, Paleontology and stratigraphy of the Shady Formation near Austinville, Virginia: Blacksburg, Virginia, Virginia Polytechnic Institute and State University, M.S. thesis, 189 p.

Wilpolt, R.H., and Marden, D.W., 1959, Geology and oil and gas possibilities of Upper Mississippian rocks of southwestern Virginia, southern West Virginia and eastern Kentucky: U.S. Geological Survey Bulletin 1072-K, p. 587-656, 3 pls. [Also available at http:// pubs.usgs.gov/bul/1072k/report.pdf.]

Wilson, C.W., Jr., and Stearns, R.G., 1968, Geology of the Wells Creek structure, Tennessee: Tennessee Division of Geology Bulletin 69, 236 p., 4 pls. in pocket.

Wilson, E.N., and Sutton, D.G., 1976, Oil and gas map of Kentucky, sheet 4, eastern part: Kentucky Geological Survey, ser. 10, 1 sheet, scale 1:250,000.

Wilson, E.N., Zafar, J.S., and Ettensohn, F.R., 1981a, Rome trough section; A stratigraphic section through the Devonian-Mississippian black-shale sequence in Tennessee, Kentucky, and West Virginia: U.S. Department of Energy [DOE] Morgantown Energy Technology Center, Eastern Gas Shale Project Series No. 500, 2 sheets. [Prepared under contract number DE-AC21-76MC05202.]

Wilson, E.N., Zafar, J.S., and Ettensohn, F.R., 1981b, Southern tie section; A stratigraphic section through the Devonian-Mississippian black-shale sequence in
Ohio, Kentucky, West Virginia, and Virginia: U.S. Department of Energy [DOE] Morgantown Energy Technology Center, Eastern Gas Shale Project Series No. 501, 2 sheets. [Prepared under contract number DE-AC21-76MC05202.]

Wilson, J.L., 1952, Upper Cambrian stratigraphy in the central Appalachians: Geological Society of America Bulletin, v. 63 , no. 3, p. 275-322, http://bulletin.geoscienceworld.org/content/63/3/275.full.pdf $+\mathrm{html}$.

Withington, C.F., 1965, Suggestions for prospecting for evaporite deposits in southwestern Virginia, in Geological Survey Research 1965, Chapter B: U.S. Geological Survey Professional Paper 525-B, p. B29-B33. [Also available at http://pubs.usgs.gov/ pp/0525b/report.pdf.]

Woodrow, D.L., and Sevon, W.D., eds., 1985, Catskill delta: Geological Society of America Special Paper $201,246 \mathrm{p}$

Woodward, N.B., and Gray, D.R., 1985, Chapter IIISouthwest Virginia, Tennessee, and northern Georgia sections, in Woodward, N.B., ed., Valley and Ridge thrust belt; Balanced structural sections, Pennsylvania to Alabama: University of Tennessee Department of Geological Sciences Studies in Geology 12, p. 7, 40-53.

Woodward, N.B., ed., 1985, Valley and Ridge thrust belt; Balanced structural sections, Pennsylvania to Alabama: University of Tennessee Department of Geological Sciences Studies in Geology 12, 64 p.

Work, D.M., Mason, C.E., and Mapes, R.H., 2009, The Pennsylvanian ammonoid succession in the Appalachian basin, in Greb, S.F., and Chesnut, D.R., Jr., eds., Carboniferous geology and biostratigraphy of the Appalachian basin: Kentucky Geological Survey Special Publication 10, ser. 12, p. 71-77, http://kgs. uky.edu/kgsweb/pubs/pubsearch.asp. 
